norden

\title{
Decision-making management procedures
}

Cost - efficiency - democracy in selected procedures in Maritime Spatial Planning
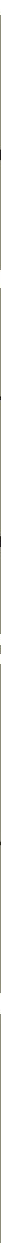

WORLD TIOONSERVATION

RECYCLING MEALTHPLANETFOBIOLOGICAL NATURALO TT $\propto$ RECYCLEGREEN RESOURCE⿳亠口冋丁 EANWATER D0 U. HABITATS OUTTECOI OGY

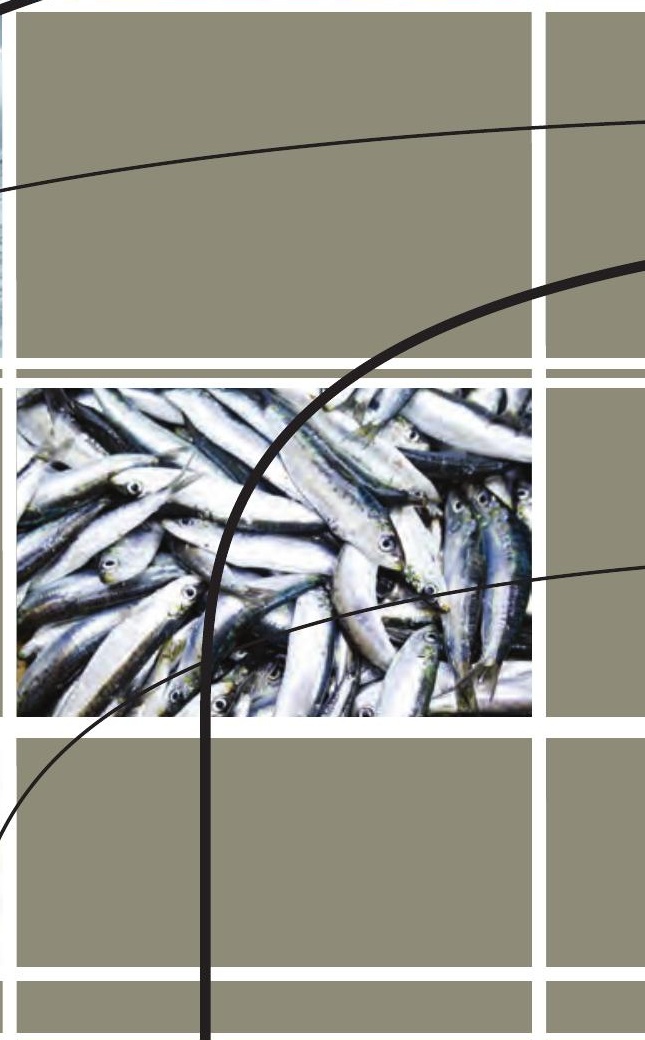



U nordon 



\section{Decision-making}

\section{management procedures}

Cost - efficiency - democracy in selected procedures in Maritime Spatial Planning

TemaNord2014:532 
Decision-making management procedures

Cost - efficiency - democracy in selected procedures in Maritime Spatial Planning

Odma Johannesen and Hans Lassen

ISBN 978-92-893-2780-0

ISBN 978-92-893-2781-7 (EPUB)

http://dx.doi.org/10.6027/TN2014-532

TemaNord2014:532

ISSN 0908-6692

(C) Nordic Council of Ministers 2014

Layout: Hanne Lebech

Cover photo: ImageSelect; Signelements; Wikimedia

Print: Rosendahls-Schultz Grafisk

Copies: 60

Printed in Denmark

This publication has been published with financial support by the Nordic Council of Ministers. However, the contents of this publication do not necessarily reflect the views, policies or recommendations of the Nordic Council of Ministers.

\section{www.norden.org/en/publications}

\section{Nordic co-operation}

Nordic co-operation is one of the world's most extensive forms of regional collaboration, involving Denmark, Finland, Iceland, Norway, Sweden, and the Faroe Islands, Greenland, and Åland.

Nordic co-operation has firm traditions in politics, the economy, and culture. It plays an important role in European and international collaboration, and aims at creating a strong Nordic community in a strong Europe.

Nordic co-operation seeks to safeguard Nordic and regional interests and principles in the global community. Common Nordic values help the region solidify its position as one of the world's most innovative and competitive.

\section{Nordic Council of Ministers}

Ved Stranden 18

DK-1061 Copenhagen K

Phone (+45) 33960200

www.norden.org 


\section{Content}

Preface

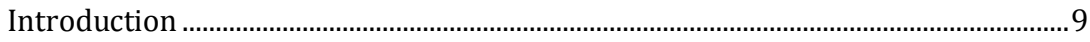

Acknowledgements .............................................................................................13

Executive Summary ..............................................................................................15

1. Maritime Spatial Planning in the Northeast Atlantic Ocean ..................................... 21

1.1 Introduction............................................................................................... 21

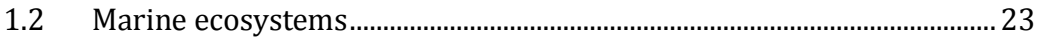

1.3 Human activities affecting the Marine Ecosystems.........................................2 24

$1.4 \quad$ Planning Human Activities in the sea .........................................................2

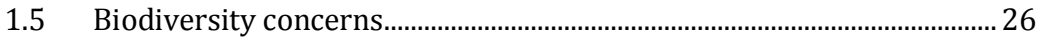

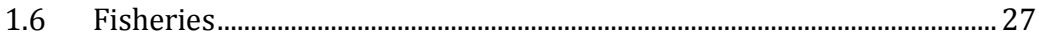

1.7 Regional International Environmental and Fisheries Organisations in the North-East Atlantic Ocean..........................................29

$1.8 \quad$ Fisheries Measures: General Approach ..................................................... 31

2. Good governance and efficient negotiations ............................................................ 35

2.1 Regulating human impact on the environment: the framework for effective decision making.............................................................................35

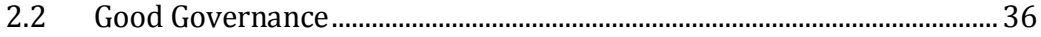

2.3 Consensus versus evidence based decision-making..................................39

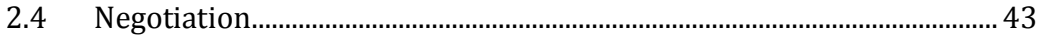

2.5 Effective negotiation.................................................................................... 45

2.6 Procedures ..................................................................................................... 47

2.7 The legal framework........................................................................................ 48

3. The role of science in the negotiation process ………………………………..... 51

4. Ecosystems, sea regions and their scale …………………………………….....5 55

4.1 Geographical division of areas in the EU-legislation.................................56

$4.2 \quad$ Natura 2000 programme ............................................................................... 60

4.3 Scale of issues, organisation and subsidiarity ........................................... 61

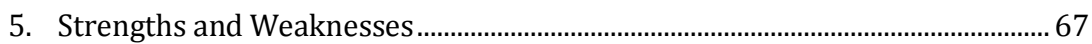

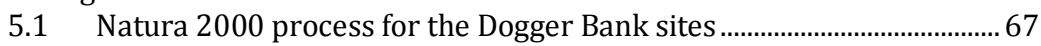

5.2 Strengths/Weakness/Threats/Opportunity (SWOT) Analysis............... 68 
6. Strengthening the Process for defining Fisheries Measures to meet Environmental Concerns

6.1 International legislation and coordination: Proposal for a Single-

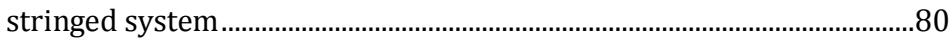

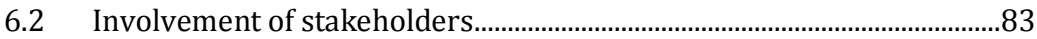

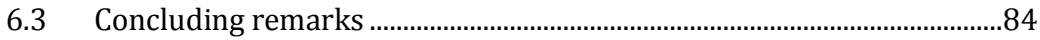

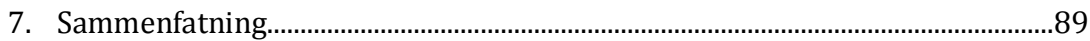

8. Annex I: Central Organisations for Maritime Spatial Planning in offshore Northeast Atlantic areas..........................................................................

8.1 The European Commission...........................................................................95

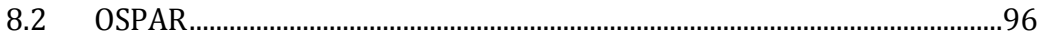

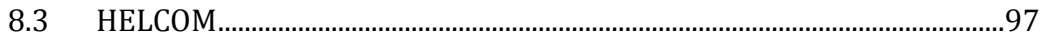

8.4 International Council for the Exploration of the Sea (ICES) ...................99

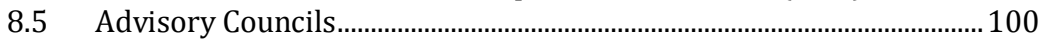

9. Annex II: Protection of habitats and species - EU Habitats Directive ............ 103

10. Annex III: Protection of wild birds - EU Birds Directive.................................... 107

11. Annex IV: Marine Strategy Framework Directive................................................ 111

12. Annex V: The Water Framework Directive .......................................................... 113

13. Annex VI: The EU's Common Fisheries Policy.......................................................... 115

13.1 The new Basic Regulation ...................................................................... 115

14. Annex VII: The Natura 2000 process - A network of protected areas .......... 119

14.1 The EU Biodiversity Strategy ……..........................................................119

14.2 Natura 2000 - Designation of sites ........................................................... 121

14.3 Preparing the selection of Natura 2000 sites........................................... 124

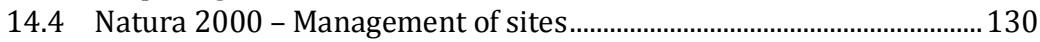

14.5 Fisheries and fisheries measures in Natura 2000 sites ........................ 135

14.6 The Commission adoption of measures ................................................. 141 


\section{Preface}

In 2012, the European Union launched a long term strategy entitled "Blue Growth" for the marine and maritime sectors. In this way, the EU's Integrated Maritime Policy is contributing towards achieving the goals of the Europe 2020 strategy for smart, sustainable and inclusive growth. Following up on this is in 2013, the European Commission put forward a Proposal for a Directive on Maritime Spatial Planning and Integrated Coastal Management. The aim of the proposal is to promote the sustainable growth of maritime and coastal economic activities and the sustainable use of marine and coastal resources. Similar considerations are ongoing in the Nordic non-EU countries.

The EU Natura 2000 network of protected areas was established in order to protect the environment in the EU. This has been ongoing for more than a decade now and there is considerable experience on how the planning procedures work. It has emerged that one particularly cumbersome element in the Natura 2000 programme is how to agree on fisheries management measures in the offshore sites. It is a major challenge to manage sustainable human activities in the marine environment because knowledge on biodiversity, structures and functions of marine ecosystems is limited and data collection in marine waters is expensive and time consuming. Decisions must be taken whilst respecting the principles of good governance, especially with respect to the involvement of stakeholders when agreeing on regulatory measures to protect the marine environment.

The Nordic Marine Think Tank has found it very relevant to study the procedures for international cooperation in the management of Natura 2000 sites in EU waters and the "lessons learnt". Such a study falls within the Think Tank's overall aim of stimulating an informed and balanced public debate that improves the quality and democracy in the decision making processes in marine policy and management. 
The Nordic Council of Ministers has kindly funded this study of strengths and weaknesses of the current EU Natura 2000 management system, including proposals on how the system might be improved.

The Nordic Marine Think Tank hopes that this study report will initiate a debate on improving the existing procedures. Changes in procedures should be debated thoroughly in relevant fora, including regional organisations, stakeholder forums, parliaments, management forums and the informed public.

Copenhagen, May 2014

Sten Sverdrup-Jensen

Chairman of the Nordic Marine Think Tank 


\section{Introduction}

This TemaNord report is an analysis of the strengths and weaknesses of the procedures applied when dealing with the environment and fisheries in the Nordic countries. It focuses on the EU procedures and legal system applied when establishing fisheries management measures in designated marine offshore protected areas: in the so-called EU Natura 2000 sites. The main example used in the analysis is the designation by three countries of Natura 2000 sites on the Dogger Bank in the North Sea.

The report deals with marine areas outside 12 nautical miles (nm). Coastal areas inside 12 nautical miles should be studied separately because the coastal state has special rights in these areas and because the coastal zone presents several issues that are not prominent in offshore areas. In the coastal areas the pressure on coastal biodiversity is complicated by additional human activities and there are more stakeholders, possibly with traditional rights, interests and authorities to consider, than in areas further offshore.

A key point of this analysis is the clashes over legal and administrative principles that occur between the fisheries and the environmental approaches. Because of this the process of developing regulatory measures becomes particularly costly and cumbersome.

The overall aim of this report is to initiate a debate that can lead to better governance when adopting fisheries management measures in marine protected areas. The long term objective is to encourage the implementation of decision-making procedures that are more efficient and more effective than the existing ones. Such an objective requires considerable public debate. Some elements of the procedures must be linked to the fact that we are dealing with different ecosystems and regional management (e.g. the Baltic Sea and the North Sea), and this requires a broader debate than the debate within each country. 
A sound scientific analysis can play a useful role as part of the public debate and the presentation of such considerations can help to bring the issue onto the public agenda.

The aim of this report is in line with the "Fitness Check" that is going on within the European Commission, aiming at identifying excessive burdens, overlaps, gaps, inconsistencies and/or obsolete measures which may have appeared over time.

The "Fitness Check" looks, inter alia, at:

- coherence in the legislation and whether there are any overlaps, inconsistencies and/or obsolete measures

- any barriers (including in other policy areas) to meeting the already agreed objectives.

The environmental and the fisheries legislation is at odds with respect to defining fisheries measures in Natura 2000 areas and this report identifies the mixture of international and national processes which have to be considered in order to achieve a more efficient process.

Scientifically defined objectives and optimal solutions must be complemented by a stakeholder process that includes their knowledge and goals in the planning and decision process within the framework of good governance. This process is time consuming, labour intensive and costly, but it may still produce the necessary legitimacy and support that an effective and efficient implementation process would require in order for it to succeed.

We hope that the report will help the evolution of procedures that are less resource demanding, more efficient, less costly, but which still ensure democracy in the process. 
A draft of this report was available for the workshop on decisionmaking management procedures in environment and fisheries - cost efficiency - democracy in selected procedures in Marine Spatial Planning. The workshop was held at the Konventum Conference Centre 22-23 October 2013 in Elsinore, Denmark. At the workshop there were presentations of experiences from Denmark, Iceland, Sweden, Netherlands and UK. The results of two EU FP7 projects (MASPNOSE and MESMA) were presented. The fishing industry also presented a reflection of the Dogger Bank process and this gave some interesting insights. ICES presented its role as provider of data and advice. Unfortunately, because of government change in Norway, a presentation of their experience was cancelled at the last moment. This report has been greatly improved by input at the workshop. 



\section{Acknowledgements}

The authors very gratefully acknowledge important input by the workshop participants and for comments to a draft of this report by the project team, Kjell Grip and Svein Jentoft. Sally Clink (BSRAC Secretariat) provided comments and helped to improve the language. The Nordic Marine Think Tank managed the project and the Nordic Council of Ministers provided funding. 



\section{Executive Summary}

The exploitation of marine ecosystem resources should be managed in a holistic, integrated manner by means of an ecosystem approach, rather than separately in each sector, e.g. the Convention on Biological Diversity (1992), ${ }^{1}$ the FAO Reykjavik declaration $(2001)^{2}$ and the EU Marine Strategy Framework Directive (2008). ${ }^{3}$

The TemaNord report is based on the marine ecosystem thinking, in particular the conservation of biodiversity in marine protected areas in the Northeast Atlantic Ocean and in maritime spatial planning of human activities. By way of example of regulating human activities we have used the development of EU fisheries measures in Natura 2000 sites. This process begins at the national level followed by cross-border coordination, rather than beginning with a coordinated effort considering the ecosystem as a whole.

In the North Sea three EU Member States have designated Natura 2000 sites in their part of the Dogger Bank sandbank in order to achieve favourable habitat conservation status. They cooperate to restrict bottom

\footnotetext{
${ }^{1}$ Convention on Biological Diversity (1992) Article 2 Ecosystem means a dynamic complex of plant, animal and micro-organism communities and their non-living environment interacting as a functional unit, https://www.cbd.int/convention/articles/default.shtml?a=cbd-02, Principle 10: The ecosystem approach should seek the appropriate balance between, and integration of, conservation and use of biological diversity and Principle 12: The ecosystem approach should involve all relevant sectors of society and scientific disciplines, https://www.cbd.int/ecosystem/principles.shtml 2 UN (FAO) Reykjavik Declaration (2001) Article 2. There is a clear need to introduce immediately effective management plans with incentives that encourage responsible fisheries and sustainable use of marine ecosystems, including mechanisms for reducing excessive fishing efforts to sustainable levels and 3. It is important to strengthen, improve, and where appropriate establish, regional and international fisheries management organizations and incorporate in their work ecosystem considerations and improve cooperation between those bodies and regional bodies in charge of managing and conserving the marine environment http://www.fao.org/docrep/meeting/

004/Y2211e.htm

${ }^{3}$ EU Marine Strategy Framework Directive (2008). Article 1(3) marine strategies shall apply an ecosystem-based approach to the management of human activities http://eur-lex.europa.eu/ LexUriServ/LexUriServ.do?uri=0J:L:2008:164:0019:0040:EN:PDF
} 
fishing gears so as to avoid degradation of the sandbank and its vulnerable species. This is the main case study used in this report.

The process begins as an environmental process involving environmental research and stakeholders in an environmental context. Then the process changes track and continues as a fisheries process (sector process) involving fisheries research and stakeholders. The information available from the environmental process is evaluated and supplemented in a fisheries context.

The report provides an analysis of the role of science and stakeholders. Science should provide the common platform for the subsequent negotiations among stakeholders. This requires a coordinated effort at the earliest stage of the process rather than several science groups supplementing each other at later stages. The latter approach is costly.

Fisheries stakeholders are organised in formal regional Advisory Councils which create a forum for stakeholder discussions on ecosystem issues in the Northeast Atlantic. While the mandate of these Councils is currently restricted to fisheries issues, they may also form the basis for organising other issues and other stakeholders so that they match the scale of ecosystems/regions. This would require that their affiliation, mandate and membership are reviewed and changed where appropriate.

\section{The report is as follows:}

- Chapter 1 gives the background to the regulation of human activities in marine offshore areas in the Northeast Atlantic Ocean.

- Chapter 2 presents the framework for good governance and a model of a negotiation framework for processes that should be agreed on before a formal process to develop measures begins. Elements that may lead to more efficient negotiations are further developed in the chapter.

- Chapter 3 describes the role of science in the negotiation processes at national and at EU level.

- Chapter 4 focuses on the definition of ecosystems, the scale of the issues, the ecosystem approach and the geographical division of marine areas in the EU legislation and the need for harmonisation.

- Chapter 5 presents an analysis in terms of strengths, weaknesses, opportunities and threats (SWOT) of the process for defining fisheries measures based on environmental concerns. 
- Chapter 6 is a proposal for strengthening the processes and procedures. On the basis of the SWOT analysis in Chapter 5, this chapter lays out some elements of an improved process and procedure for the international establishment of regulating human impact in Natura 2000 areas or areas established with similar intentions.

- Annex I presents some of the central international organisations, Annexes II-VI provide short summaries of the central EU legislation, i.e. the Habitats Directive, Birds Directive, Marine Strategy Framework Directive, the Water Framework Directive and the Common Fisheries Policy. Finally Annex VII presents the Natura 2000 network and the process from designation to regulation of human activities.

The current process involves national proposal for designation of sites that are evaluated at EU level prior to the national adoption of the sites. The designation of sites is followed by national proposals for fisheries measures in the sites. These proposals are based on a coordinated analysis involving EU member states with fishing interests in the sites. The European Commission is empowered by means of delegated acts on the request from Member States involved to adopt fisheries measures in the Natura 2000 sites. The adoption of measures is notified to the European Parliament and the Council of Ministers and enters into force within two months if they have no objections.

The proposals for improving the efficiency of the structure and the procedures when establishing fisheries management measures in offshore protected areas (Natura 2000 sites in the EEZ) ${ }^{4}$ include the following:

${ }_{4}^{4}$ These proposals should be applied to cross-boundary sites as well as to those coastal sites (inside $12 \mathrm{~nm}$ ) that involve fishing interests of other member states. 
- International coordination.

- Coordination between countries should take place at the earliest possible stage in regional organisations.

- Make more effective use of the international organisations (ICES, ITC/Biodiversity, GBIF) 5 for creating databases (access to data) and coordination of data analysis. The weaker the scientific basis, the greater the need for solutions based on democratic debate to ensure that decisions are uncontested.

- Introduction of a single-stringed system structuring the national and international processes based on commitment from all participants.

- The procedure should be divided into four sections: bringing the issue onto political agenda, the scientific advice, stakeholder involvement and agreement on measures. These should be welldefined phases in the process. Furthermore, there should be an integrated environment-fisheries process including integrated scientific analysis. This procedure is currently carried out three times before a fisheries management decision is finally taken (in the form of a delegated act adopted by the Commission on the request from Member States involved). Firstly, at national level, including consultations with neighbouring countries (off shore areas), secondly at the EU level and thirdly again at national level/ in fisheries at regional level.

- Adoption of timeframe and mechanisms that assure that deadlines are adhered.

- Involvement of stakeholders.

- The present system includes few incentives to reach consensus and the process needs to be redefined in order to increase the pressure on the participants to reach consensus.

- Involvement of all stakeholders should be organised by extending and adjusting the existing Regional Advisory Councils (RACs) (now Advisory Councils) to the new single-stringed system.

${ }^{5}$ Global Biodiversity Information Facility http://www.gbif.org/ 
- The funding at different stages, including the funding of the involvement of science and of stakeholders should be reconsidered and compared to the current expenditure, time consumption and labour intensity.

- International legislation.

- The need for harmonisation of maritime policies is recognized as well as the international dimension of exploitation and conservation. Regulating human activities, including fisheries, requires international agreement. The conflicts that are pointed out between fisheries and environmental legislation should be addressed.

- The single-stringed process that is proposed above should be embedded in the legal framework.

Such changes can only be implemented in the long term and should be debated thoroughly in relevant fora, including regional organisations, stakeholder forums, parliaments, management forums and in the public in general. 



\section{Maritime Spatial Planning in the Northeast Atlantic Ocean}

\subsection{Introduction}

Maritime Spatial Planning (MSP) of the use of the sea area outside the coastal zone, but within the Exclusive Economic Zone (EEZ) is largely based on national legislation, e.g. for oil and gas exploration and production. However, there is an international dimension because some issues cross EEZ boundaries and because activities in one area affect the environment in neighbouring areas. So countries cooperate on regulating the environmental impact under the umbrellas of several international organisations.

Transport and fisheries are regulated through United Nations (UN) and regional organisations. Within the European Union (EU), the Common Fisheries Policy (CFP) regulates fisheries. Other activities are regulated through different framework directives. When EU Member states develop and implement a sea region thematic strategy, according to the EU Marine Strategy Framework Directive, they should aim at the conservation of the marine ecosystems and address all human activities that impact the marine environment.

MSP has a clear geographical scope and decision processes are confined to those States that are directly affected. Starting from a North-East Atlantic perspective the legal frameworks are defined in the legislations of EU Member States and the EU. Outside the EU, Norwegian legislation is particularly important. In the Baltic Sea in addition to the EU and its Member States, the Russia Federation is also a player. 
Philippe Sands has reviewed the principles of international environmental law. ${ }^{6}$ While Maritime Spatial Planning (MSP) is legally a national issue, countries do cooperate on MSP because of the cross-border issues. Maritime Spatial Planning in the Nordic countries is discussed in detail by Blæsbjerg et al. (2008).7 In March 2013 the EU Commission proposed a Directive on establishing a framework for maritime spatial planning and integrated coastal management. ${ }^{8}$

In this report we restrict ourselves to considering how fisheries regulations are being defined to meet environmental concerns in offshore marine area within EEZs. We have chosen these procedures for our study because they clearly illustrate the conflicts between the environment and the fisheries legislation. Most fish migrate over large areas while conservation of habitats can be considered at a much smaller scale.

The European legislation on nature conservation is amongst the most important drivers for MSP in Europe. This legislation is a part of the EU contribution to implementing the 1992 Convention on Biological Diversity. ${ }^{9}$ The two most significant elements are the Birds Directive ${ }^{10}$ providing a framework for the identification and classification of Special Protection Areas (SPAs) for rare, vulnerable or regularly occurring migratory species, and the Habitats Directive ${ }^{11}$ requiring member states to select, designate and protect sites that support certain natural habitats or species of plants or animals as Special Areas of Conservation (SACs). Together, the SACs and the SPAs create a network of protected areas across the EU, known as the Natura 2000 network.

\footnotetext{
${ }^{6}$ Philippe Sands, 2003. Principles of International Environmental Law 2nd Edition Cambridge University Press.

${ }^{7}$ Blæsbjerg, M., Pawlak, J.F., Sørensen, T.K., and Vestergaard, O, 2009. Maritime Spatial Planning in the Nordic Region: principles, perspectives and opportunities. TemaNord. 2009:528. Nordic Council of Ministers, Copenhagen, Denmark.

${ }^{8}$ Proposal for a Directive of the European Parliament and of the Council establishing a framework for maritime spatial planning and integrated coastal management, http://eur-lex.europa.eu/LexUriServ/ LexUriServ.do?uri=COM:2013:0133:FIN:EN:PDF

${ }^{9} \mathrm{http}: / /$ www.cbd.int/convention/text/

${ }_{10}$ Council Directive 79/409/EEC of 2 April 1979 on the Conservation of wild birds, OJ L 103, 24 March 1979, as amended 2007/147/EC and 2013/17/EU of 13 May 2013.

${ }^{11}$ Council Directive 92/43/EEC of 21 May 1992 on the Conservation of natural habitats and of wild fauna and flora, OJ L 206, 22 July 1992.
} 
The knowledge on biodiversity, structures and functions of marine ecosystems is limited and data collection in marine waters is expensive and time consuming. However, the Biodiversity Convention (1992) requires that actions to protect areas and species be taken and should not wait until sufficient knowledge is available. Planning the use of the marine ecosystems must be done without full knowledge. The less the knowledge base there is in planning and decision making process, the more good governance is needed, especially with regard to the involvement of stakeholders.

There is a long and good tradition of involving stakeholders in maritime planning and the decision making processes. The stakeholders are organised on the basis of private initiatives, e.g. WWF, Greenpeace, SAR and national fisheries organisations. The Common Fisheries Policy (CFP) defines Advisory Councils: their structure, membership and tasks and because they are embedded in the CFP, these Councils hold a special position.

\subsection{Marine ecosystems}

An ecosystem is a community of living organisms (plants, animals and microbes) in conjunction with the non-living components of their environment (such as air, water and mineral soil), interacting as a system. ${ }^{12}$ Marine ecosystems have distinct organisms and characteristics that result from the unique combination of the physical factors that create them. Humans, with their cultural diversity, are an integral component of ecosystems and because human well-being is a central objective in the exploitation of the marine ecosystems, humans are singled out in maritime spatial planning.

Marine waters cover about two-thirds of the surface of the Earth. The world's oceans and seas as a whole can be considered as one ecosystem which is subdivided into many large marine ecosystems e.g. UNEP ecoregions. However, in some contexts a small, local marine area may also be considered as a micro ecosystem.

12 http://en.wikipedia.org/wiki/Ecosystem 
Ecosystems may have different characteristics even if they are located in similar environments. All ecosystems are open systems, irrespective of the scale and are more or less inter-linked. A micro ecosystem can be a driver for the functioning of an ecosystem at macro scale.

Dynamics and functions of the ecosystems are affected by the shape of the ocean floor, the internal currents and the major ocean current systems, the sun, wind and weather. Ecosystems provide food, energy, minerals etc. for human benefit. Ecosystems are impacted by human activities and humans determine the use, utilization and conservation of marine resources and environment.

An ecosystem is interactively interwoven. However, the links that are to be addressed are not confined to the natural links, but links exist because of the industry structure, e.g. the tuna industry is multi-national and there are fleets that move between ecosystems. A holistic analysis should take into account both the "natural" interactions as well as those created by human activities.

\subsection{Human activities affecting the Marine Ecosystems}

Humans make many different uses of the marine environment and each sector is regulated almost separately. These human activities may be grouped as follows:

- Fisheries.

- Mining (incl. sand and gravel extraction).

- Diffuse sources (agriculture, eutrophication).

- Waste (litter, sewage).

- Hazardous substances (heavy metals, organic substances) both from diffuse and hot spots sources.

- Radioactivity (from hot spots).

- Energy production (oil and gas, wind, wave, tidal).

- Transport.

- Tourism - eco-tourism and other recreational use of the marine environment. 
These human activities are regulated through a number of EU Directives including the Habitats Directive, (Annex II), the Birds Directive, (Annex III), the Marine Strategy Framework Directive, (Annex IV), Water Framework Directive, (Annex V) and the Common Fisheries Policy, (Annex VI). About $80 \%$ of the marine pollutants that threaten the marine environment stem from land-based activities (eutrophication, hazardous substances and radioactivity) and the regulation of these threats is based on national legislation subject to EU standards laid down in the Water Framework Directive.

There are conflicts between these activities. Jentoft and Knol ${ }^{13}$ provide an overview and discussion with a specific North Sea perspective.

\subsection{Planning Human Activities in the sea}

The United Nations Law of the Sea (1982) ${ }^{14}$ provides the legal framework and its roots go back to the late middle Ages when individual states required exclusivity in the oceans. In the $17^{\text {th }}$ century Hugo Grotius ${ }^{15}$ argued that the sea outside the coastal zone was international territory and that all nations were free to use the sea for seafaring trade. However since then, the rights of coastal states to defend, use and regulate coastal and offshore waters have been further discussed and developed.

Although the Parties to the United Nations Convention on the Law of the Sea (UNCLOS) (1982) are conscious that the problems of oceans space are closely interrelated and need to be considered as a whole, ${ }^{16}$ much of the structure, regulation and planning of the sea continues to be based on

\footnotetext{
13 Jentoft S. and Knol M., 2014. Maritime Studies 2014, 12:13 http://www.maritimestudiesjournal.com/ content/12/1/13

14 http://www.un.org/depts/los/convention_agreements/texts/unclos/unclos_e.pdf UNCLOS entered into force in 1994.

${ }^{15}$ Hugo Grotius, or Huig de Groot, (10 April 1583 - 28 August 1645), was a Dutch lawyer and philosopher. His most important legal work was the book Mare Liberum (Freedom of the seas), published in 1609. Mare Liberum was formulated to the Dutch East India Company.

16 Preamble of the United Nations Convention on the Law of the Sea, http://www.un.org/depts/los/ convention_agreements/texts/unclos/unclos_e.pdf
} 
sector-by-sector considerations guided by mainly commercial interests in using and exploiting the seas and their resources. Regulation is supplemented by conflict resolution between legitimate operators, as well as fighting illegal interference with legal trade. Recently, Frank Maes reviewed the legal basis for Maritime Spatial Planning. ${ }^{17}$ It was only after 1994 when UNCLOS came into force that it became legally clear how the coastal states should manage their territorial seas, exclusive economic zones and continental shelves. On the high seas the use and conservation of resources is to a large extent still a legally unsolved issue.

The planning tasks are often solved within the sector legislation that might seem the most appropriate. The individual sectors are best qualified to assess any issue related to their sector. However, this means that planning and regulating many maritime activities is fragmented and can be found in many different pieces of legislation.

An overall integrated planning includes consideration of the conservation of the marine environment. Environmental concerns have become increasingly important during recent decades and although the conservation of the marine environment is a cross-sectoral issue, the environmental authorities, responsible for the conservation of the marine environment, operate in parallel with other sectors. This setup does not seem coherent.

\subsection{Biodiversity concerns}

Biodiversity is a hot topic in the international debate, see Science. ${ }^{18}$ The answer to better managing the loss of biodiversity is, among others, Maritime Spatial Planning (MSP). MSP addresses a wide range of human use of the marine environment. Much of the MSP is developed sector by sector according to the rules and traditions in each sector. However, each sector,

\footnotetext{
17 Frank Maes, 2008. The international legal framework for Maritime Spatial Planning. Marine Policy 32 (2008) 797-810.

18 "....clear to the scientific community that the current rate of biodiversity loss puts the future well-being of citizens in the EU and world wide at risk (European Commission, 2010)" from European Environment Agency website http://www.eea.int, see also http://www.cbd.int/decision/cop/ default.shtml?id=12268 for the CBD strategic plan for Biodiversity 2011-2020.
} 
including fisheries should integrate environmental concerns and this includes biodiversity concerns into their policy, Agenda 21 (1992). ${ }^{19}$

The Natura 2000 programme is used throughout this report as the example of environmental conservation concerns. Natura 2000 is defined within the scope of the Biodiversity Convention. Fisheries are among the human impacts on the environment and restrictions are required to meet environmental objectives. The national environmental management authorities are responsible for the protection of the marine environment.

\section{Box I}

\section{Conservation of marine biodiversity}

Conservation of marine biodiversity, ecosystem approach in fisheries and the integration of environmental concerns into sector policies are on the agenda of fisheries management. Fisheries can and will contribute to the conservation of marine biodiversity, including fisheries management in protected areas. In some cases the innovation of fishing gears may allow the continuation of low impact fisheries in protected sites. If fisheries in a site are banned the fisheries will continue outside the site and the impact on the first site may be transferred to other areas of the marine environment (displacement).

\subsection{Fisheries}

Throughout this report, fisheries are used as the example of economic activity that impacts the marine environment. Fishing is an economic activity at sea, exploiting the fish resources and exploitation pressure is built to match the demand in the market. Fisheries provide an economic contribution to the sector, create jobs for the crew, for workers in the ports and landing sites, in the processing industry and in transport and trade.

\footnotetext{
19 The United Nations Conference on Environment \& Development. Rio de Janerio, Brazil, 3 to 14 June 1992 - AGENDA 21, Chapter 8.3: The overall objective is to improve or restructure the decision-making process so that consideration of socio-economic and environmental issues is fully integrated, http://sustainabled evelopment.un.org/content/documents/Agenda21.pdf
} 
Fishing also provides employment for the shipbuilding industry, navigation equipment, supply of equipment for the detection and identification of fish stocks and the manufacture of fishing gear. Fisheries exploit the marine ecosystems and have side effects on the bottom fauna and produce unwanted by-catches. Fisheries management aims inter alia at balancing the benefits in the form of food with the adverse effects on the marine ecosystem.

\section{Box II}

\section{Fishery}

Contributes to food supply of healthy foods and feed for fish farming. Fisheries have had historically and still have a key role in many coastal regions. The EU is a net importer of fish (approx. 65\% of the demand is met through imports).

Faroe Islands, Greenland, Iceland and Norway export the largest share of their catches. The EU is a major importer of fish and fish products from these countries.

Fisheries regulations have a multitude of objectives among others are:

- to resolve conflicts between fishermen and fisheries

- to resolve conflicts between different uses of the sea (e.g. oil and gas exploration and production or transport)

- to conserve juvenile fish and spawners

- to conserve habitats (e.g. spawning and nursery grounds and cold water corals).

Fisheries management has a long history with national legislation. Management has well established international cooperation and within the EU has a strong legal basis for management matching the migratory nature of fish stocks. The development of fishing vessels, equipment and gears in the last century has enabled fishing to expand offshore and to deeper waters. This process has been constantly ongoing. Increased capacity combined with efficiency per fishing unit has led to overfishing. Mitigating the negative effects of overfishing requires detailed regulation of fisheries to ensure sustainability (maintain fish stocks at a level that provides fishing opportunities in coming years). The increased fishing capacity also affects by-catches in areas with mixed fish stocks and non-target species. 
The Natura 2000 process helps to understand how maritime spatial planning may function and how the EU decision making procedures for environmental and fisheries management of the marine ecosystem are at odds. $^{20}$ Fisheries management based on the Common Fisheries Policy (CFP) is a centralised decision-making process, while the environmental process is bottom-up based on national proposals that are coordinated in a subsequent step. The national processes are confined by international agreements defining the general framework and goals and common guidelines. This asymmetry leads to inefficient processes when fisheries are dealt with in an environmental context and vice-versa.

There is therefore a need to reflect on these procedures both from an environmental as well as from a fisheries angle. These reflections should lead to recommendations for organising the decision processes better.

Aspects of the Natura 2000 process have been analysed by the MASPNOSE ${ }^{21}$ project, which focused on the North Sea. The ongoing EU project on Transboundary Planning in the European Atlantic Ocean (begun March 2013) looks at the process in areas in the Celtic and Irish Sea and in the south Guadiana/Bay of Cádiz.22

\subsection{Regional International Environmental and Fisheries Organisations in the North-East Atlantic Ocean}

Intergovernmental organisations coordinate the regulation of human impact on the marine ecosystems. In the Northeast Atlantic there are two central environmental organisations: OSPAR with the Northeast Atlantic Ocean as convention area and in the Baltic Sea HELCOM with a similar role for the Baltic Sea. A third organisation, the Arctic Council was established

\footnotetext{
20 Jaap Leijen, 2011. The Habitats and Birds Directives versus the Common Fisheries Policy: A Paradox Merkourios 2011 - Volume 27/Issue 73, pp. 19-45.

21 Pastoors M. (Ed), 2012. Preparatory Action for Maritime Spatial Planning in the North Sea. MASPNOSE Final report. University of Wageningen, Netherlands.

22 http://www.irishseamaritimeforum.org/wp-content/uploads/2013/06/TPEA-Glasgow.pdf
} 
in 1991 with a wide scope extending beyond environmental issues, e.g. the Council agreed in 2011 the Arctic Search and Rescue Agreement, which was the first binding treaty concluded under its auspices.

OSPAR defines five strategies to address the main threats to the marine environment (the Biodiversity and Ecosystem Strategy, the Eutrophication Strategy, the Hazardous Substances Strategy, the Offshore Industry Strategy and the Radioactive Substances Strategy) and promotes cooperation among its member countries to protect the marine environment. HELCOM approaches the same problems in the Baltic Sea through different working groups and a Baltic Sea Action plan.

Governments are contracting parties or observers in intergovernmental, regional and global organisations and agreements. Governments represent the interests of their country.

In the North-East Atlantic outside coastal zones numerous international organisations are involved in Maritime Spatial Planning and cover regional/global issues related to fisheries.

\section{Box III}

\section{The Northeast Atlantic Ocean}

Governments and International Organisations involved in Maritime Spatial Planning and covering regional/global issues related to fisheries.

\section{Governments (countries and entities) with competence in Maritime Spatial Planning:}

- EU Member States (Denmark (excl. Faroe Islands and Greenland), Sweden, Finland, Estonia, Latvia, Lithuania, Poland, Germany, Netherlands, Belgium, France, UK, Ireland) etc.

- Norway, Iceland and in the Baltic Sea Russian Federation. In the NorthEast Atlantic the Faroe Islands and Greenland have extended selfgovernance and are important players particularly in a fisheries context. 


\section{Intergovernmental organisations}

- EU institutions (Commission, European Parliament, Council of Ministers).

- OSPAR (Protection and conservation of the marine environment of the North-East Atlantic).

- HELCOM (Baltic marine environment protection).

- NEAFC (North-East Atlantic fisheries).

- NASCO (salmon conservation).

- ASCOBANS (small cetaceans of the Baltic and North Seas).

- NAMMCO (North Atlantic Marine Mammals Commission).

- IWC (large whales, International Whaling Commission).

- IMO (safety and security of shipping, prevention of marine pollution, UN International Maritime Organisation).

- Arctic Council.

- ICES (Compilation, analysis and advice on status of marine area and living resources, International Council for the Exploration of the Sea).

\section{Non-government international organisations}

- (Regional) Advisory Councils (include representation of both fishing industry and environmental NGOs).

- Industry organisations (e.g. Europêche).

Within the EU system the (Regional) Advisory Councils are given a role to coordinate stakeholder input to issues defined by the political level. In a Natura 2000 context for fisheries measures the central international organisations include EU, OSPAR, HELCOM, ICES and the ACs and these are presented in more detail in Annex I.

\subsection{Fisheries Measures: General Approach}

Fisheries measures based on environmental concerns in offshore areas are agreed through international negotiations followed by national implementation, in the EU Member States by the EU. 
Within the EU the CFP lays down rules for access by fishers to an area. The organisations that are involved depend on the area where the regulation is considered. Fisheries issues beyond the jurisdiction of EU policy, (e.g. deep sea fisheries outside national jurisdiction) are discussed either with non-EU countries or in the General Assembly of the United Nations (UNGA). The participation of EU delegations (Member States and the EU Commission) is based on a negotiating mandate agreed within the EU. The results are implemented in the EU and its Member States.

A fundamental concern is matching the scale of the problem to the solution. Human activities within the $200 \mathrm{~nm}$ limits (national EEZs) are mostly regulated through national regulations and as mentioned above, this can create a conflict where the scale of the problem does not match the legislative scale.

Where the issue is global, a global organisation is invoked, for example IWC $^{23}$ (large whales). For issues with a smaller scope regional organisations are involved. The global organisation mostly addresses general objectives and management principles (e.g. UN FAO Code of Conduct for Responsible Fisheries) and rarely specific regulations. However, detailed regulations related to international shipping and navigation is a concern of the IMO.

Regulating whaling (large whales) is done on the global scale by the International Whaling Commission (IWC) and tuna fisheries are carried out on an almost global scale; although not all 193 UN member nations have a legitimate interest in these activities.

Regulation of tuna fisheries includes a global dimension because some tuna fishing fleets operate on a global scale. The competence is within the regional fisheries organisations. They cooperate with the UN FAO which provides a global approach e.g. FAO has been involved in establishing global fishing vessel lists and other management measures.

Stakeholders are faced with the challenge of organising themselves on a corresponding scale, which creates the problem of assuring a democratic foundation for such NGOs.

23 IWC: International Whaling Commission. 
However, the legislation is weak (insufficient pressure on finding a solution) and issues remain unresolved for years. Outside the marine area a key example is the discussions of the global response to climate change.

Global Maritime Spatial Planning ends up as general recommendations which at the regional scale are met with frustration by the industry as the concerns are unspecific and the issues may be of only minor relevance to the region.

The Maritime Spatial Planning process that regional organisations in the North East Atlantic Ocean deal with is illustrated in Figure 1. The process starts with the formulation of the problem. This mostly takes place outside the regional organisations at national level. Only after making the issue more concrete, are the problems brought to the regional organisations. These provide the framework for negotiations between the countries involved at government level, but national delegations very often include both industry as well as NGO representatives. However, the process can be complicated when the international and national processes are intermingled.

Figure 1. General outline of the process around the regional environmental organisations HELCOM and OSPAR

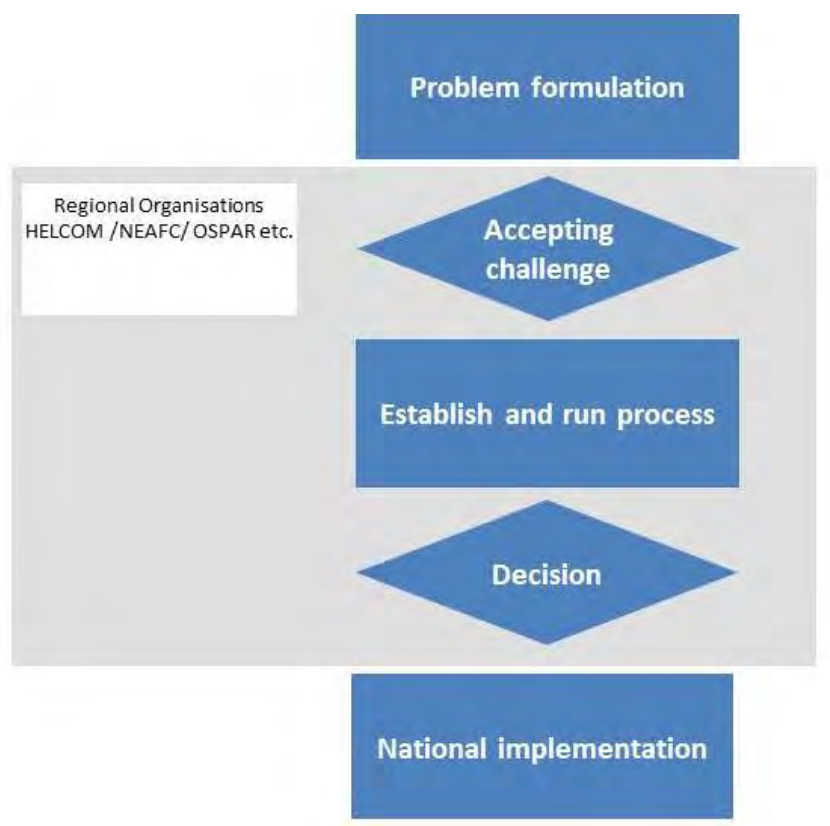


Many of the ideas that are presented in this report have a long history including the possible role of the ACs as stakeholder representatives. One example of this is a joint RAC meeting held in $2008 .{ }^{24}$ At this meeting topics such as the need for the involvement of stakeholders in the beginning of the designation process, the opportunity for the ACs to provide knowledge at an early stage, the lack of coherence between Member States in designating offshore sites, the lack of participation of local fishing communities were all raised.

The European Environment Agency ${ }^{25}$ gives a snapshot of the current state of coastal regions, assesses the policies for managing coastal regions and highlights the need for better information and better monitoring tools.

Outside the Northeast Atlantic stakeholder participation in regulating the impact on the marine environment is also discussed, e.g. the project on the Strategic Partnership for the Mediterranean Sea Large Marine Ecosystem (MedPartnership) 2013 MedMPAnet ${ }^{26}$ is about stakeholder participation and a toolkit for the identification, designation and management of marine protected areas.

\footnotetext{
24 March 5th - 6th, 2008 four Regional Advisory Councils organised a meeting at the Scottish Parliament, Holyrood Edinburgh, to discuss Offshore Marine Protected Areas, http://nsrac.org/wp-content/ uploads/2009/08/Report_sc20080305.pdf

${ }^{25}$ EEA Report No 12/2013. Balancing the future of Europe's coasts - knowledge base for integrated management, http://www.eea.europa.eu/publications/balancing-the-future-of-europes

26 http://www.rac-spa.org/sites/default/files/mpa_stakeholder_toolkit.pdf
} 


\section{Good governance and efficient negotiations}

\subsection{Regulating human impact on the environment: the framework for effective decision making}

Governance is the framework in which management decisions are reached and implemented.

The management of offshore marine areas is based on limited information. Science provides the knowledge basis for management decisions, but the decisions themselves include value judgement beyond science.

While some fisheries and the resources targeted are well documented, there are unfortunately many issues where the science is weak and where the scientific conclusions may be debated e.g. the evidence on biodiversity, structures and functions of marine ecosystems is limited.

Improving the knowledge base takes time and requires expensive funding. Data collection in the marine waters and on the seabed is especially expensive and time consuming. On many issues we cannot wait with the protection and conservation of the marine nature and its sustainable use and exploitation of the sea until we have satisfactory knowledge. The use and exploitation of the marine ecosystems and the conservation of biodiversity of the ecosystems must therefore be planned by responsible decision makers and without full knowledge.

Managers have to balance protection with sustainable use. Finding this balance is challenging and demands good governance. Managers supplement the knowledge basis with dialogue with stakeholders. These parties are environmental organisations (NGOs) and organisations representing users and exploiters.

Many issues have cross-boundary effects, so the decision making process must have an international dimension at the political level. International cooperation and joint compilation of data are also needed. As noted 
in Chapter 1 there are organisations that serve this function in the Northeast Atlantic at the political level e.g. OSPAR and HELCOM. For the Northeast Atlantic Ocean, the scientific input may be compiled and summarized through ICES.

Policy makers need to consult the interests involved and those interests should have an important influence on the use and the protection of the marine environment. Good Governance inter alia provides guidelines on how to involve stakeholders in decision making processes. Good governance in the management of the marine environment is examined in the context below.

\subsection{Good Governance}

Governance relates to political and institutional processes and outcomes that are deemed necessary to achieve the political goals. Good governance should deliver on the political goals which respect a number of criteria including the legitimate interests of involved parties.

In the context of environmental conservation and fisheries regulations, the institutions are expected to promote prosperous fisheries with minimal environmental impacts on the ecosystem. Such fisheries are exploiting stocks at or around MSY ${ }^{27}$ Experience suggests that achieving this goal mostly requires either the cooperation of all parties involved or forceful command and control systems. ${ }^{28}$

Good governance can be organised around three areas:

- Democratic institutions.

Good governance includes avenues for the public to participate in policymaking either through formal institutions or informal consultations through institutions that encourage civil society and local communities to

\footnotetext{
27 MSY: Maximum Sustainable Yield, target for fisheries exploitation pressure as agreed at UN WSSD 2002 in Johannesburg.

${ }^{28}$ In a broader context see UN Human Rights office http://www.ohchr.org/en/Issues/Development/

GoodGovernance/Pages/GoodGovernanceIndex.aspx
} 
formulate and express their positions on issues of importance to them. The process for developing appropriate regulations includes mechanisms of accountability and transparency, culturally sensitive policy tools to ensure that services are accessible and acceptable to all and paths for public participation in decision-making.

- Service delivery.

The process has to deliver on the political goals which have been defined through a democratic process. In order to deliver, the institutions involved need a clear mandate and resources.

- Rule of law.

The administrative system is based on a clear set of rules and a control and enforcement system that assures a level playing field for all those involved.

UN Human Rights mentions anticorruption as a fourth element of good governance. We see this as part of providing a level playing field and expect that corruption is of little concern in the systems that we consider. The perceived corruption index 2012 is shown in Figure $2^{29}$ (yellow low, red high degree of perceived corruption).

Figure 2 Perceived level of corruption 2012. UN Human Rights organisation

${ }^{29}$ http://cpi.transparency.org/cpi2012/results/ 


\section{Box IV}

\section{Principles of Good Governance}

General:

- Clear definition of responsibilities at the Union, regional, national and local levels.

- Accounting for regional specificities through a regionalised approach.

- Regulatory measures in accordance with the best available scientific knowledge.

- Transparent availability of data to the appropriate scientific bodies, other bodies with a scientific or management interest, and other defined end-users.

- Long-term perspective.

- Administrative cost efficiency.

Policy makers need to consult the interests involved and those interests have an important influence on the level of use and the conservation of the marine environment:

- Involvement of stakeholders - from concept to implementation of the measures.

- Respect for private life, the protection of personal data and confidentiality rules.

- Respect for traditional rights.

EU specific considerations:

- Subsidiarity: the primary responsibility of the flag State.

- Consistency with other Union policies.

- Knowledge base: the use of impact assessments as appropriate.

- Coherence between the internal and external dimension of the Common Fisheries Policy.

- Involvement of stakeholders, in particular of Advisory Councils, at all stages. 


\subsection{Consensus versus evidence based decision- making}

Regulating human activities that impact the environment must balance two main issues:

- Human benefits extracted from exploiting ecosystems.

- Human impacts that may degrade ecosystems.

Sustainable exploitation strikes this balance so the system can also cope with the impact in the long term. However, there are value judgements associated with the weight that is attached to the impacts from human activities: what is considered acceptable degradation by one, may be considered unacceptable by another.

There are two approaches to defining fisheries and environmental regulations:

- Scientifically defined objectives and finding the optimal solution based on these objectives.

- Political process through negotiation.

The first approach is based on the assumption that on the basis of an agreed set of goals there is an objective - scientific - solution to defining the required regulation. The other approach sees the conflict as a disagreement on value issues, but assumes that the interested parties share a wish to harvest the human benefits and that there is a norm for consensus seeking. A central issue is the basis for the decisions: whether they seek consensus-based decision-making or whether evidence-based decisionmaking is preferred.

We argue below that good governance leans towards a consensus model rather than an evidence-based model. These two models are not exclusive, but are extremes with a continuum in between. In the extreme an evidence-based model assumes that given a set of objectives, there is an optimal solution that can be calculated based on a set of data. Data are however rarely completely conclusive and the understanding of the context in which to interpret the data is for marine ecology mostly open to 
debate, although this uncertainty is in some cases overplayed to serve political goals.

Furthermore, there is no complete agreement on the objectives among stakeholders. Even when the set of objectives is agreed on, there is no agreement on the weighting between the objectives. We are also dealing with issues that are very difficult to compare: On the one hand, we are conserving the ecosystem, its biodiversity and its functions. On the other hand, the sea provides us with food, energy, transport routes, sand and gravel, etc. which all have a market.

The discussions on ecosystem services ${ }^{30}$ provide an elaborate system for evaluating all these services, but in practise the stakeholders look at the direct implications of the proposed restrictions and evaluate them on their merits and challenge any solution that may be calculated. Finally, as already mentioned, our knowledge of the functioning of the marine ecosystem is limited and even if one could agree on a set of operational objectives and how to weight these, the scientists can only make the calculations based on best available knowledge and this knowledge is not undisputed.

The political process is required to consider the relevant objectives, how they should be weighted and whether the knowledge available is accepted as a proper basis for calculating a solution.

The other extreme, the purely political solution without considering the evidence, is perhaps just as irresponsible as the pure evidence based solution. Although our knowledge of how the marine ecosystem functions is limited, there is knowledge available and it is possible on a qualified basis to assess whether a proposed regulation is likely to deliver on the objectives or not. For this reason the negotiation model that is presented later in this chapter includes checks on whether the negotiation results are likely to deliver on the stated objectives.

The difference between the two approaches is the level on which one approaches the discussion of values either at an abstract level through the definition of objectives, or at a specific level looking at the concrete issue at

\footnotetext{
30 Millennium Ecosystem Assessment, 2005. Ecosystems and Human Well-being: Synthesis. Island Press, Washington, DC.
} 
hand. In both cases there is a political stage where stakeholder interests and the ethics and values of all involved parties are essential. In many situations, defining a general approach is difficult because the situations in which the objectives and general rules may apply have not been well defined.

The scope of the Habitats Directive was widened through court cases. The final verdict by the European Court of Justice in $2005^{31}$ ruled that the Directive also applied to marine offshore waters beyond the near coastal zone. This is an argument for being specific, although specific arrangements can also be used for establishing general rules through prejudice. A discussion on laying down principles - defining objectives - often ends in fuzzy language. An example is the Biodiversity Convention 1992 and its implementation in the EU - most recently with the EU biodiversity strategy in 2010 - postponing achieving the goals. In other words, the convention is neither precise nor does it allocate power for its implementation and is thus inadequate to deliver on the goals that were originally intended. In the EU, Member States have to take the necessary measures to achieve or maintain good environmental status in the marine environment by 2020 at the latest (Article 1 of the Marine Strategy Framework Directive).

We argue that good governance should be based on a model that strikes a balance between the two extremes, i.e. accepting that the process is political, but also that the political room for manoeuvre is restricted by our knowledge.

\subsubsection{Stakeholder involvement}

Stakeholder involvement is crucial in the management of the marine environment. Fishermen collect information through experience from their operations at sea. They have also observed changes over time during their operations. The environmental NGOs play an important role by amongst other things asking questions about the consequences of human activities and the impact on biodiversity and habitats.

${ }^{31}$ Case C-6/04, Commission v United Kingdom and Case C-131/05, Commission v United Kingdom. 
The stakeholders are involved in the Natura 2000 process at national level and at EU level. The stakeholder organisations reflect the main issues of their organisations, be they local, regional or/and global.

This report is based on marine ecosystem thinking, in particular the conservation of biodiversity in marine protected areas in the Northeast Atlantic Ocean and in Maritime Spatial Planning of human activities. There are many regional stakeholder organisations providing important input to the Natura 2000 process.

Many of these organisations concentrate on specific environmental concerns in the marine environment. In fisheries the Advisory Councils cover stakeholder interests in the management of fisheries of a region in the marine environment (formerly Regional Advisory Councils). The Advisory Councils are established under the Basic Regulation of the Common Fisheries Policy.

\subsubsection{The Nordic model}

The governance model that is investigated is the Nordic administrative model with its characteristics of being incremental, inclusive and consensus-based. The model is designed with the aim of regulatory agencies enjoying the confidence of both those they control and those on behalf of whom they exercise control - the political executive. This implies that regulation, control and supervision will be studied in a wider democratic context. A considerable democratic dilemma is how regulatory agencies are to gain enough autonomy to function efficiently, but not that they gain so much freedom as to become politically uncontrollable.

The administrative model is based on a set of values that includes high weights attached to human rights issues such as stakeholder involvement and consensus seeking. The SWOT analysis presented in Chapter 5 is built on attaching high values to such considerations. The Nordic model goes a long way to achieving cooperation of all those involved and it sees the alternative control and command system as a last resort that is invoked only reluctantly.

The Nordic administrative model considers the following key attributes: 
- Transparency.

- Responsibility.

- Accountability.

- Participation.

- Responsiveness (to the needs of the people).

- Rejection of prescriptive approaches or only using these as a last resort.

- Strong "anticorruption" norm and deterrence (this issue is not part of our analysis).

These principles are also advocated in the EU legislation.

The Nordic model is negotiation-based, so the next step is to review the elements of a negotiation.

\subsection{Negotiation}

The negotiation process is a series of actions that seek to provide an agreeable outcome for all involved parties. Negotiations can take place at an informal level and the process in these cases can become less structured than that which is described below.

Establishing the negotiating environment (Step 1 below) is based on a political decision that calls for a solution to a particular problem. In most cases the political decision is accompanied by general directions on where the solution should be found. This step is not considered in this report, but it includes interesting questions such as what moves the EU ministers to decide on a Natura 2000 programme. This decision on conservation and, if required, on improvement of the ecological status of habitats and sea bird populations was accompanied by requirements for defining Natura 2000 sites.

Negotiation steps (modified from): ${ }^{2}$

32 Tanya Alfredson and Azeta Cungu, 2008. Negotiation Theory and Practice A Review of the Literature. Policy Assistance and Resource Mobilization Division, FAO, Rome, Italy. 
1. Establishing the environment around the negotiations:

a. Define the issue and put it on the political agenda.

b. Identification of stakeholders.

c. Agreement among stakeholders to negotiate.

2. Preparing negotiations: Understanding the issue. This step is normally initiated before the parties enter into formal talks, but can overlap with step 3 (see below) of the negotiations. Based on arguments presented by the involved parties, a secretariat may be asked to clarify the facts around the argument, the uncertainties or even where there may be a knowledge gap.

3. Negotiations:

a. This step may be very short if the information search suggests a solution and this solution is acceptable to all involved parties. In that case steps b) and c) may be by-passed.

b. Each side to present its case below. This involves explaining what the individual's goal is, what he/she wants to gain, and what he/she is willing to offer up in return. All involved must listen to each other for the negotiations to proceed successfully.

c. A continuous back and forth of ideas, options, and arguments between the sides. This part of the process varies greatly depending on the type of negotiations taking place and they may take place over several sessions in order to allow the parties to reflect on various solutions, including time to consult with their constituency on the proposed solution.

d. Presenting and editing the solution. Once the process of finding a solution is completed, negotiations enter into the final steps of the process. The agreement is clearly laid out in a written agreement.

e. The agreement is reviewed by the parties. Furthermore, the processes that we are concerned with include as part of the review of the agreement an independent scientific check to see if the solution is likely to deliver the desired outcome. This review is in many cases done within the International Council for the Exploration of the Sea (ICES). The feed-back from such an evaluation may cause the agreement to be amended as needed until it meets the satisfaction of all involved.

f. Signing the agreement. 
This completes the negotiation process, the procedures of which we discuss in this report. However, a successful process includes of course the parties honouring their obligations and fulfilling the agreement. This normally includes exchange of information on how the parties meet their obligations.

The agreement should include provisions for conflict resolution and as an ultimate step, provisions that allow one or more parties if dissatisfied with the agreement to re-open the negotiations (typically at negotiation step 2) to amend the agreement and to find a better, more sustainable solution.

\subsection{Effective negotiation}

Based on the definition of the negotiation process above we are now able to discuss what constitutes an effective negotiation (steps 2 and 3) procedure. We propose that it has the following characteristics:

- There is a secretariat that provides:

- factual knowlegde to the process

- logistics for the process

- drafting of proposals for solution

- editing of the final agreement.

- The procedure provides the opportunity for all stakeholders:

- to provide the secretariat with factual information relevant to the issue at hand

○ to present their case and preferred solution to all involved

- to comment on the contributions of other stakeholders

- to present ideas and options for solutions to the process.

- The energy (time and money) that is required to take part in the process is optimal, i.e. it allows on the one hand for the provision of information and stakeholder input, but on the other hand do so with as little energy as possible. In short, to use the time and money that is necessary for a clear process without the machine running idle. 
For environmental issues, the procedure is based on national processes and is not very well defined.

There are two main issues with this procedure. The first is already mentioned in the introduction to this section that the international mechanism that forces a coherent approach and consistent solutions to similar problems is weak. The Natura 2000 programme based on the Habitats and Birds Directives is a good example of the problems that exist within the EU legislation in this field. The Natura 2000 Dogger Bank process did not involve OSPAR, which would have provided the secretariat backup and a framework for the negotiations. Instead, a multilateral process was established on an ad-hoc basis.

The second issue is that often step 3c (presenting ideas and proposing solutions) cannot be brought to completion even though all available relevant information has been brought to the table and all participants have exhausted their arguments. The reasons are: needs to consult with constituencies or simply that there is no agreement/consensus on any solution. The procedure does not include a clear milestone that makes it possible to draw the conclusion - no agreement - but instead the process is kept open, waiting for input from the outside that will force the process to stop whether by a positive result in the form of a consensus solution or by abandoning the process.

From the perspective of the secretariat this can be very frustrating because the process is kept open by asking the secretariat to provide further information that is neither required nor seriously considered in the subsequent process.

An efficient negotiation process therefore requires supplementing the above list with:

- A mechanism that stops the iteration in step 3 at a point when all information is on the table and all arguments have been heard. The stopping mechanism is usually based on pressure from outside e.g. in the form of a politically defined deadline.

The result should be respected by all parties so that a re-opening clause is not invoked. This is achieved through a consensus solution and a credible control and enforcement system. This is outside our considerations. 


\subsection{Procedures}

A procedure is the formal structure around a process. Processes need to be structured to provide a transparent process and a level playing field. These are essential elements for the process to deliver a desired result. A procedure can be explained by a time line with check points (also called "milestones") of the process right up until the outcome. These check points make it clear who is doing what when and where.

Effective negotiation must take place at the most appropriate point during the process. Therefore we have to look at the procedures in which negotiations take place. If something goes wrong, the first things we focus on are the check points. If we locate weaknesses in one or more check points, we correct them. If nothing seems to be wrong at any of the checkpoints, we have to look into the time line as a whole and between check points. The result of the analysis could be that we need to add new check points in the time line. The check points must be carefully added at the right place in the time line in order to ensure that the procedure can be followed with a successful outcome. The objective of decision making procedures is to make sure that things are done properly, so as to achieve a final outcome that reflects the balances of the input during the process. In many cases, the final outcome reflects the results of choices made when all relevant available information and opinions have been presented and considered.

Most legislation provides decision making procedures in the management. Procedures can vary from one area to another. The procedures are mostly based on the tradition and culture of each individual management system and practise has established a firm basis for the proper procedures including consultation practises and advisory committees, etc. The EU directives are not very prescriptive with respect to the proper procedures for the process that leads up to the decision and the basis for evaluating the procedures are therefore sought in the general principles of good governance.

Management is amongst other things based on the biological situation of the resources. However, knowledge on the status, migration and productivity of fish stocks is often uncertain. Scientific studies typically provide new and better data, but also changes over time in the marine environment might be reasons for reviewing the management procedures. Some resources are subject to frequent changes and the proper response 
is adaptive management. Some legislation includes requirements for regular review of management strategies.

\subsection{The legal framework}

Regulating human impact on the marine environment is sector based in EU and in non-EU Nordic countries and regions. Within the EU system the use of the sea is under the Maritime Policy and under this policy the Marine Strategy Framework Directive (MSFD) assures consistency and coherence among the sectors under the overall EU Maritime Policy. However, when dealing with use of offshore areas, there are issues that reach beyond the EU family and involve countries outside the EU: Iceland, Norway and the Russian Federation, plus the Faroe Islands and Greenland. In this context, the EU plays a dominant role. Many of the threats to Europe's marine resources require cooperation and collective action to be tackled effectively. It is within this context that the Integrated European Maritime Policy, which aims to provide a coherent framework for joined up governance of the marine environment, is being developed.

Maritime spatial plans and integrated coastal management strategies must apply an ecosystem-based approach to facilitate co-existence and prevent conflicts between competing sector activities in marine waters and coastal zones. They must also aim to contribute to fostering the sustainable development and growth of the fisheries and aquaculture sector, including employment in fisheries and connected sectors, ensuring the preservation, protection and improvement of the environment as well as the prudent and rational use of natural resources, notably in order to achieve good environmental status, halt the loss of biodiversity and degradation of ecosystem services and reduce marine pollution risks, and to ensure climate resilient coastal and marine areas. ${ }^{33}$

\footnotetext{
${ }^{33}$ Ehler, Charles, and Fanny Douvere. Maritime Spatial Planning: a step-by-step approach toward ecosystem-based management. Intergovernmental Oceanographic Commission and Man and the Biosphere Programme. IOC Manual and Guides No. 53, ICAM Dossier No. 6. Paris: UNESCO. 2009 (English).
} 
The objectives of the above mentioned rules have been adapted to the environmental concerns current for the adoption of the rules.

The two central EU Directives in the Natura 2000 process are presented in some detail in Annex II (Habitats and species) and Annex III (Birds). The Common Fisheries Policy is presented in Annex VI, while Annex VII presents the Natura 2000 programme and the processes governing designation and fisheries measures processes and in particular how fisheries regulation fits into this programme.

The Commission has tabled a "Proposal for a directive on maritime spatial planning and integrated coastal management." 34 This proposal is intended to establish a framework aiming at promoting the sustainable growth of maritime and coastal economies and the sustainable use of marine and coastal resources by establishing and implementing spatial plans and integrated coastal management strategies. The Commission proposal applies to marine waters and coastal zones, see Article 2(1) of the proposal.

\footnotetext{
34 Proposal for a Directive of the European Parliament and of the Council establishing a framework for maritime spatial planning and integrated coastal management, http://eur-lex.europa.eu/ LexUriServ/LexUriServ.do?uri=COM:2013:0133:FIN:EN:PDF
} 



\section{The role of science in the negotiation process}

Scientific input is fundamental in defining management measures, so scientists often play a central role in such processes. The EU CFP specifies that Commission proposals must be accompanied by a scientific analysis of the problem and if possible, science is invited to advise on appropriate management measures. Scientists thus have a special role in the negotiation process apart from the stakeholders.

The negotiation process involves two main roles: those who are directly involved as "proper" stakeholders and a support group:

- Main players

- Public servants representing national governments or the Commission.

- Stakeholders: Non-government representatives for industries (such as fisheries, energy production and maritime transport), environmental NGOs, regional or local Communities, etc.

- Scientists who have taken on an advocacy role and are becoming players in their own right.

- Support

- Scientists compiling and presenting existing information, and as a quality assuring filter on information presented by stakeholders and authorities.

- Advisors evaluating the likely outcome of a proposed set of measures on well-defined objectives.

- Mediators facilitating the process.

Management authorities base their proposals on the best available information and scientific advice. At national level, the authorities will draw primarily on national information and advice. At EU-level, the Commission 
draws on the European Topic Centre on Biological Diversity for the assessment of conservation of biodiversity in Natura 2000 sites and on ICES for the assessment of fisheries measures. The CFP has also defined a Scientific, Technical and Economic Committee (STECF) that advises the Commission on fisheries management issues. These organisations are network organisations based on national institutes. They provide an umbrella that assures coordination and joint analysis of the input that is generated nationally.

ICES is in a unique position to provide and process information that is relevant for the process. Some may claim that this can be done in a transparent manner that is beneficial to all of the main players. Clearly this claim is built upon an expectation that ICES enjoys credibility in all camps. This assumption may be questioned e.g. as part of the evaluation of the Dogger Bank process, the fishing industry found it necessary to have its own scientific consultants in future similar processes.

ICES advises on whether the proposed measures are likely to achieve the stated conservation objectives. Within the EU system the Scientific, Technical and Economic Committee on Fisheries (STECF) provides a similar service with respect to fisheries issues. National marine research institutes may take on this role on issues which have no international dimension and countries may bilaterally decide on how to fill this role, e.g. through ad-hoc advisory groups. In the Dogger Bank case ICES provided advice on the relevance of the measures.

ICES is an organisation with 20 member countries and the ICES governance bodies want to make certain that the organisation does not provide judgements that do not have full support in the ICES science community. ${ }^{35}$ ICES also wants to protect its integrity: For these reasons ICES has significant difficulties in being an integral partner of the process. One reason for this is that science lacks data. There are many more questions raised in the process than there are firm science based answers. All too often data are scarce and not quite fit for purpose. There is an immense

\footnotetext{
35 Wilson D.C. 2009 The parad ox of Transparency. Science and the Ecosystem Approach to Fisheries Management in Europe. MARE Publication Series No. 5 Amsterdam University Press.
} 
grey zone where there are some data and analysis available and where some guidance based on judgement can be given. However, there is no firm science position on the matter.

This on the other hand leaves room for the consultants who can help the process with more soft input than what ICES finds prudent. It also complicates the process because scientific input becomes part of the negotiating process. This situation and its consequences is described and discussed in extensive literature within social science. Roe ${ }^{36}$ gives a general overview, whereas Pálson describes the process from an Icelandic fisheries perspective. ${ }^{37}$

During the N2000 designation process and the process of fisheries measures in the sites, stakeholders and science provide new information not only at national level, but at EU level as well, and the discussions during the process take into account such new information. Such an adaptation during the process is desirable and important in order to achieve an optimal result.

The question is whether science could provide information and advice at the earliest possible stage, i.e. when the designation process begins. To this end we need to examine the weaknesses and strengths of the science and to identify opportunities where the science could exchange and discuss its contribution to the benefits of the process from the very beginning and throughout the whole process. The SWOT-analysis below shows the most obvious characteristics of the science. The analysis shows that the scientific institutions are very strong in their own specialised field, i.e. sector science, including data, assessment and advice. On the other hand, they are not so strong in ecosystem considerations. They also have some weaknesses in including and discussing information from other sectors in their considerations.

\footnotetext{
36 M. Roe 2013. Maritime Governance and Policy-Making. Springer Verlag, London.

37 Pálson Gíslí, 2006 Nature and Society in the age of Postmodernity. In Aletta Biersack and James B. Greenberg (eds) Reimagening Political Ecology- Duke University Press.
} 
SWOT I

\begin{tabular}{|c|c|c|c|c|}
\hline & Strengths & Weaknesses & Opportunities & Threats \\
\hline \multicolumn{5}{|l|}{ National science } \\
\hline & $\begin{array}{l}\text { National science acts } \\
\text { under contract and on } \\
\text { request } \\
\text { They have good } \\
\text { access to data and are } \\
\text { involved in data } \\
\text { collection, assessment } \\
\text { and advice and for all } \\
\text { these reasons, output } \\
\text { is often relevant in } \\
\text { the situation }\end{array}$ & $\begin{array}{l}\text { Generally the national } \\
\text { institutes are sector } \\
\text { based and the per- } \\
\text { spective is not holis- } \\
\text { tic. So there is only } \\
\text { coordination with } \\
\text { other sectors when } \\
\text { needed at national } \\
\text { level } \\
\text { Only coordination at } \\
\text { international level } \\
\text { when needed. There } \\
\text { is little ecosystem } \\
\text { approach }\end{array}$ & $\begin{array}{l}\text { MSP process may } \\
\text { provide opportunities } \\
\text { to strengthen coordi- } \\
\text { nation on a regular } \\
\text { basis and to coordi- } \\
\text { nate data collection } \\
\text { and assessment }\end{array}$ & $\begin{array}{l}\text { National (local) } \\
\text { science may become } \\
\text { weaker } \\
\text { The starting point is } \\
\text { still at national level } \\
\text { and at sector level }\end{array}$ \\
\hline \multicolumn{5}{|c|}{ European Topic Centre on Biological Diversity } \\
\hline & $\begin{array}{l}\text { European Topic } \\
\text { Centre on Biological } \\
\text { Diversity has long and } \\
\text { consistent experience } \\
\text { with the assessment } \\
\text { of Natura } 2000 \text { sites } \\
\text { in the EU on land and } \\
\text { at sea }\end{array}$ & $\begin{array}{l}\text { The assessment is } \\
\text { based on available } \\
\text { information. It cannot } \\
\text { take into account } \\
\text { information available } \\
\text { at the discussions on } \\
\text { fisheries measures } \\
\text { There is a lack of } \\
\text { ecosystem approach }\end{array}$ & $\begin{array}{l}\text { MSP process may } \\
\text { provide opportunities } \\
\text { for stronger and } \\
\text { regular access to } \\
\text { information }\end{array}$ & $\begin{array}{l}\text { The biodiversity and } \\
\text { the N2000 approach } \\
\text { may be weakened }\end{array}$ \\
\hline \multicolumn{5}{|c|}{ International Council for the Exploration of the Sea (ICES) } \\
\hline & $\begin{array}{l}\text { ICES has a long } \\
\text { tradition (since 1901) } \\
\text { on collecting data } \\
\text { from fisheries and } \\
\text { environment, check- } \\
\text { ing and qualifying } \\
\text { data, assessing data } \\
\text { and providing advice } \\
\text { on a yearly basis and } \\
\text { on ad hoc basis } \\
\text { ICES has decided to } \\
\text { keep a distance, } \\
\text { separating provision } \\
\text { of science from } \\
\text { participating directly } \\
\text { in the negotiation } \\
\text { process. }\end{array}$ & $\begin{array}{l}\text { Primarily advice on } \\
\text { fisheries and effects } \\
\text { of fisheries on fish } \\
\text { stocks and marine } \\
\text { environment. Mostly } \\
\text { fisheries sector based } \\
\text { There is a lack of } \\
\text { ecosystem approach }\end{array}$ & $\begin{array}{l}\text { ICES is a major } \\
\text { institution on marine } \\
\text { environment with } \\
\text { long and strong } \\
\text { tradition on storing } \\
\text { and handling data } \\
\text { from the sea. It could } \\
\text { play a major role in } \\
\text { MSP planning of data } \\
\text { and advice }\end{array}$ & $\begin{array}{l}\text { The main focus may } \\
\text { be taken from the } \\
\text { fisheries } \\
\text { Because of its arm's } \\
\text { length approach ICES } \\
\text { may become irrele- } \\
\text { vant to the MSP }\end{array}$ \\
\hline
\end{tabular}




\section{Ecosystems, sea regions and their scale}

The negotiations that we are concerned with must provide decisions that, when properly implemented, deliver an ecosystem approach to management.

The Convention on Biological Diversity (CBD) ${ }^{38}$ has described the ecosystem approach as a strategy for the integrated management of land, water and living resources that promotes conservation and sustainable use in an equitable way. The application of the ecosystem approach will help to reach a balance of the three objectives of the Convention: Conservation; sustainable use; and the fair and equitable sharing of the benefits arising out of the utilization of genetic resources.

Furthermore, according to the CBD, an ecosystem approach is based on the application of appropriate scientific methodologies focused on levels of biological organisation, which encompass the essential structure, processes, functions and interactions among organisms and their environment. It recognizes that humans, with their cultural diversity, are an integral component of many ecosystems.

This focus on structure, processes, functions and interactions is consistent with the definition of "ecosystem" provided in Article 2 of the Convention on Biological Diversity: "'Ecosystem" means a dynamic complex of plant, animal and micro-organism communities and their non-living environment interacting as a functional unit."

The term "ecosystem" can refer to any functioning unit at any scale. In other words, the scale of analysis and action should be determined by the problem being addressed. It could, for example, be a grain of soil, a pond, a forest, a biome or the entire biosphere. The ecosystem approach requires

38 http://www.cbd.int/ecosystem/description.shtml 
adaptive management to deal with the complex and dynamic nature of ecosystems and the absence of complete knowledge or understanding of their functioning.

There is a fundamental conflict between the biological approach to the specification of regulations and the legal unit (EEZ). The biological approach focuses on the biological features e.g. habitats, while the legal approach is mainly concerned with sovereignty. A biological site that is heavily exploited and for which restrictions on human activities are therefore considered may stretch across national borders.

This is not particular to marine areas, but applies also to land based nature reserves that may cross national borders. Countries need to agree on the desired biotic and abiotic status and on the basis of such agreed targets for the biological status; they need to cooperate in defining the approach to restricting the activities so that the desired biological status can be achieved. There are also examples of interactions between micro ecosystems and the status in a larger ecosystem, e.g. mussels with pelagic larvae that can populate a neighbouring site and the land based sources of hazardous substances and nutrients.

Management must be adaptive in order to be able to respond to such uncertainties and must contain elements of "learning-by-doing" or research feedback. Measures may need to be taken, even when some causeand-effect relationships are not yet fully established scientifically.

\subsection{Geographical division of areas in the EU- legislation}

Habitats Directive: The aim of the Habitats Directive is to promote the maintenance of biodiversity through conservation of natural habitats and of wild fauna and flora.

The measures contained in the Habitats Directive must be designed to maintain or restore natural habitats and species of wild fauna and flora of community interest. They must take account of economic, social and cultural requirements and regional and local characteristics.

The Habitats Directive operates with nine bio-geographical regions, see Article 1(c) (iii) and the whole of the territory in each Member State of the 
EU, see Article 2(1). The regions are very large. To make the assessment of status of habitats and species easier, the bio-geographical regions can on an ecological basis (and not according to administrative or national boundaries) be further sub-divided into regional seas or sub-regional seas. Sub-divided regions are developed for the Baltic Sea region.

According to Article 4(2) of the Directive, the Commission, in agreement with each Member State, must establish a list of sites of Community importance on the basis of the criteria in Annex III of the Directive. The assessment of sites includes among other things the geographical situation of the sites in relation to migration routes of species and whether they belong to a continuous ecosystem on both sides of or more international Community frontiers and global ecological value of the sites for the bio-geographical regions concerned. The network must enable the natural habitat types and the species habitats to be maintained or, where appropriate, restored to favourable conservation status in their natural range.

Birds Directive: According to the Birds Directive Member States must take the necessary measures to preserve, maintain or re-establish a sufficient diversity and area of habitats for all species of birds in their territory.

According to Article 4, paragraph 1, (and paragraph 2 on migratory species) of the Birds Directive Member States have to classify the most suitable territories in number and size as special protection areas (SPA) for the conservation of species of Annex 1 (species in danger of extinction, vulnerable species, rare species and species requiring particular attention) to ensure their survival and reproduction in their area of distribution, and take similar measures for regularly occurring migratory species not listed in Annex 1, see Article 4(2). This protection includes marine birds. Many species of wild birds naturally occurring in the European territory of the Member States are migratory species.

So the preservation, maintenance and re-establishment of biotopes and habitats must include the creation of protected areas. Designation of SPA's according to the Birds Directive is an integral part of the Natura 2000 system.

The Birds Directive operates within the European territory of the Member States; see Article 1 of the Birds Directive. According to the Birds Directive there must be national lists of species in danger of extinction or particularly endangered species, taking into account their geographical 
distribution, see Annex V(a). Annex V(b) covers listing and ecological description of areas particularly important to migratory species on their migratory routes and as wintering and nesting grounds.

Common Fisheries Policy: According to Article 2(1) of the Basic Regulation of the European Parliament and of the Council on the Common Fisheries Policy (CFP), the CFP has to ensure that fishing and aquaculture activities are environmentally sustainable in the long-term and are managed in a way that is consistent with the objectives of achieving economic, social and employment benefits, and of contributing to the availability of food supplies.

According to Article 2(3) of the CFP the objectives include implementation of the ecosystem-based approach to fisheries management to ensure that negative impacts of fishing activities on the marine ecosystem are kept to a minimum, and must endeavour to ensure that aquaculture and fisheries activities avoid the degradation of the marine environment. The Common Fisheries Policy must also contribute to the collection of scientific data, see Article 2(4).

In this respect we should note that according to Article 1 of the Basic Regulation, the scope of the Common Fisheries Policy (CFP) covers the conservation of marine biological resources and the management of fisheries and fleets exploiting such resources on the territory of Member States to which the Treaty applies.

The basic fisheries regulation applies to the territory of Member States to which the Treaty applies, see Article 2(b). This is further detailed in Article 4(2) as the Northeast Atlantic waters: North Sea, Baltic Sea, North Western waters, South Western waters, and waters around Madeira and the Canary Islands. The regulation also applies to areas in the Mediterranean Sea and the Black Sea.

The Marine Strategy Framework Directive (MSFD) requires Member States to develop and implement marine strategies to protect, prevent the deterioration or, where practicable, restore marine ecosystem in areas where they have been adversely affected. Member States shall take measures to achieve or maintain good environmental status in the marine environment by the year 2020 .

Good environmental status is achieved when biological diversity is maintained, when among other things populations of all commercially fish 
and shellfish are within safe biological limits (population age and size distribution are indicative of healthy stocks), when food webs are normal and when the sea-floor integrity is at a level that ensures that the structure and functions of the ecosystems are safeguarded.

The Marine Strategy Framework Directive applies to all marine waters as defined in Article 3(1), and takes account of the transboundary effects on the quality of the marine environment of third States in the same marine region or sub region, see Article 2(1). "Marine waters" means waters, the seabed and subsoil on the seaward side of the baseline from which the extent of territorial waters is measured extending to the outmost reach of the area where a Member State has and/or exercises jurisdictional rights Article 3(1a), and coastal waters Article 3(1b). "Marine region" means a sea region which is identified under Article 4. Marine regions and their sub regions are designated for the purpose of facilitating the implementation of the Directive and are determined taking into account hydrological, oceanographic and bio-geographic features, see Article 2(2).

When implementing their obligations under the Marine Strategy Framework Directive, Member States have to take account of the fact that marine waters covered by their sovereignty or jurisdiction form an integral part of, among others, the following marine regions, see Article 4(1): the Baltic Sea, the North-East Atlantic Ocean, see Article 4(1).

Member States may, in order to take into account the specificities of a particular area, implement this Directive by reference to subdivisions at the appropriate level of the marine waters referred to in paragraph 1 , provided that such subdivisions are delimited in a manner compatible with among others the following marine sub-regions: in the North-East Atlantic Ocean, the Greater North Sea, including the Kattegat, and the English Channel, the Celtic Seas, see Article 4(2).

The management must keep up with and has to be updated when new information on the ecosystems is available, including any changes in ecosystems. The term "ecosystem" can refer to a functioning unit at any scale.

The sectors integrate the ecosystem approach into their sector management, without an overreaching general, broad ecosystem management approach, e.g. this is reflected in the sectors' legislation by the division of marine areas. Fisheries management operates with ICES areas, while the Birds Directive operates with the geographical areas of the Member 
States. SWOT II below shows strengths and weaknesses in the sector division of marine areas.

The Marine Strategy Framework Directive operates with eco-regions, the Habitats Directive with bio-geographical regions and the Common Fisheries Policy with ICES zones. These regions seem to have similar boundaries. One step towards ecosystem thinking could be to harmonise the regions and this harmonisation might include the Birds Directive.

SWOT II

\begin{tabular}{|c|c|c|c|}
\hline Strengths & Weaknesses & Opportunities & Threats \\
\hline \multicolumn{4}{|l|}{ Legal basis for fisheries measures in Natura 2000 sites } \\
\hline $\begin{array}{l}\text { The Habitats Directive operates } \\
\text { with nine bio-geographical } \\
\text { regions } \\
\text { The Birds Directive operates } \\
\text { with European territory of the } \\
\text { Member States } \\
\text { The Marine Strategy Frame- } \\
\text { work Directive operates with } \\
\text { ecoregions } \\
\text { The CFP operates with geo- } \\
\text { graphical areas/ICES zones }\end{array}$ & $\begin{array}{l}\text { The starting point } \\
\text { is not ecosystems }\end{array}$ & $\begin{array}{l}\text { Revision of the } \\
\text { areas based on } \\
\text { ecosystems }\end{array}$ & $\begin{array}{l}\text { New areas } \\
\text { may divert } \\
\text { focus from } \\
\text { the sector }\end{array}$ \\
\hline
\end{tabular}

\subsection{Natura 2000 programme ${ }^{39}$}

Natura 2000 is the centrepiece of EU nature and biodiversity policy. It is an EU-wide network of nature protection areas established under the 1992 Habitats Directive. The aim of the network is to assure the long-term survival of Europe's most valuable and threatened species and habitats. It is comprised of Special Areas of Conservation (SAC) designated by Member States under the Habitats Directive, and also incorporates Special Protection Areas (SPAs) which they designate under the 1979 Birds Directive. Natura 2000 is not a system of strict nature reserves where all human activities are excluded. Whereas the network will certainly include nature reserves, most of the land is likely to continue to be privately

${ }^{39}$ Modified from http://ec.europa.eu/environment/nature/natura2000/ 
owned and emphasis will be on ensuring that future management is sustainable, both ecologically and economically. The establishment of this network of protected areas also fulfils a Community obligation under the UN Convention on Biological Diversity.

Natura 2000 applies to Birds Sites and to Habitats Sites. At EU level the geographical areas are divided into bio-geographical regions. The sites are discussed at bio-geographical seminars held for each bio-geographical region in which the sites are located. It also applies to the marine environment after an EU court case ruling in 2005.

The Natura 2000 process to define the fisheries regulations on the Dogger Bank is the main case study used in this report. This process, although not yet brought to completion (April 2014), has already been analysed from various angles, e.g. MASPNOSE (2012),40 Degnbol ${ }^{41}$ and Boedecker et al. 2006.42

\subsection{Scale of issues, organisation and subsidiarity}

The criteria for good governance include the involvement of relevant stakeholders i.e. users of the ecosystem extracting benefits (e.g. fisheries) and environmental NGOs focusing on the protection of the environment. This invites regionalisation of the problems which inter alia allows relevant stakeholders to concentrate on issues in "their" area and this is a contribution to an efficient procedure. However, issues have different scales and the procedure should give all relevant stakeholders a chance to let their voices be heard and for procedures to be efficient the scale of the

\footnotetext{
40 Martin Pastoors, Saskia Hommes, Frank Maes, David Goldsborough, Birgit de Vos, Marian Stuiver, Bas Bolman, Thomas Kirk Sørensen, Vanessa Stelzenmüller, Preparatory Action on Maritime Spatial Planning in the North Sea,( MASPNOSE) Final Report (D1.3.3) Centre for Marine Policy, Leeuwarden, University. ${ }^{41}$ Ditte Degnbol 2012. The science of Sandbanks on the Dogger Bank. PhD Thesis - Aalborg University The Doctoral School of Engineering and Science. Department for Development and Planning - Innovative Fisheries Management. July 2012.

42 Dieter Boedecker, Jochen C Krause, Henning von Nordheim (eds). Progress in Marine Conservation in Europe: Natura 2000 Sites in German Offshore Waters. Springer 2006. 263pp.
} 
problem must be carefully considered. The box below presents some marine issues and their scale ranging from global to local.

\section{Box V}

\section{Scale of Issue}

- Global.

- Regional - Northeast Atlantic.

- Local (Typically coastal).

\section{Scope of regulation}

- Whaling, Biodiversity conservation.

- Tuna fisheries (total Atlantic Ocean), Biodiversity conservation, Radioactivity, Waste, Diffuse sources, Hazardous substances, Fisheries, Transport, Diffuse sources (Eutrophication), Mining, Biodiversity, Energy, Waste.

- Coastal Fisheries, Transport, Mining, Diffuse sources (Eutrophication), Energy, Waste.

\section{Organisation (examples)}

- UN, IWC.

- Regional Fisheries Management Organisations (EU, JNRFC, NEAFC, NASCO, etc.), OSPAR, HELCOM, ASCOBANS, NAMMCO.

- National State.

\section{Preferred Approach}

- UN or global organization.

- Regional Management Organisation.

- National or bilateral agreements.

This classification is used in the definition of conventions: Global e.g. UN, IWC, Regional e.g.: OSPAR, HELCOM, NEAFC, NAMMCO, EU (EC) and at national and local levels. There are of course issues within the national borders that are regional.

These organisations were established on the basis of specific current problems and were restricted by the parties' geographical prevalence of the problems. 
Management is most often directed at an activity performed by a legal entity (an economic unit), e.g. oil and gas producing firm or fishery. There is therefore a different dimension to the scale issue depending on whether the regulation problem should be addressed at the national level or whether there is an international dimension. Where there is an international dimension there are special problems with control and enforcement related to sovereignty concerns for the national state.

Activities are regulated by means of rules and regulations (legal approach) and good governance suggests that stakeholders are involved in the formulation of the restrictions that are laid down in the rules and regulations. Establishing the rules and regulations must also within the EU be in accordance with the principle of subsidiarity. This is one of the central principles in the EU, meaning that political decisions in the EU must always be taken at the lowest possible administrative and political level, and as close to the citizens as possible, other than the areas where the EU has exclusive competence. This means that the EU can only act if it would be better to implement the legislation in question at EU rather than at national, regional or local level.

Before presenting a proposal for new legislation, the Commission must always examine whether the proposal conforms to the principle of subsidiarity and justify this. In general terms, the principle of subsidiarity means that two conditions must be fulfilled in order for the EU to be able to legislate in areas in which both the EU and the Member States can do so: ${ }^{43}$

- The aim of a proposal could not be fulfilled to an adequate degree by the Member States drawing up their own legislation.

- The aim of a proposal could be better fulfilled by legislating at EU rather than national level.

The principle of subsidiarity is closely related to the principle of proportionality, in accordance with which EU measures should not go beyond what is necessary to fulfil the Treaty objectives.

43 (From “Folketingets Oplysning http://www.eu-oplysningen.dk/euo_en/spsv/all/61/) 
Maritime Policy: On 12 ${ }^{\text {th }}$ March 2013, the European Commission published a proposal for a Directive of the European Parliament and of the Council establishing a framework for maritime spatial planning and integrated coastal management. ${ }^{4}$

According to Article 5(1) of the proposal the objectives of maritime spatial plans and integrated coastal management strategies are to facilitate the co-existence and prevent conflicts between competing sector activities in marine waters and coastal zones, facilitated by the application of an ecosystem-based approach.

The plans and strategies must aim to contribute to:

- securing the energy supply

- promoting the development of maritime transport, efficient and costeffective shipping routes

- fostering the sustainable development and growth of the fisheries and aquaculture sectors

- ensuring the preservation, protection and improvement of the environment as well as the prudent and rational use of natural resources, notably in order to achieve good environmental status, halt the loss of biodiversity and degradation of ecosystem services and reduce marine pollution risks

- ensuring climate resilient in coastal and marine areas.

According to Article 4, each Member State has to establish and implement a maritime spatial plan or plans and an integrated coastal management strategy or strategies.

Maritime spatial plans should at least map the actual and potential spatial and temporal distribution of maritime activities in marine waters. Integrated coastal management strategies should at least contain an inventory of existing measures applied in coastal zones and an analysis of the need for additional action for the appropriate management of activities in coastal zones.

${ }^{44} \mathrm{http}: / /$ eur-lex.europa.eu/LexUriServ/LexUriServ.do?uri=COM:2013:0133:FIN:EN:PDF 
The plans and strategies should be based on best available data, strategic environmental assessments and should be mutually coordinated. Member States have to cooperate with each other and with third countries to ensure that plans and strategies are coherent across coastal zones and marine regions.

All relevant stakeholders and authorities should be appropriately consulted on the draft plans and strategies.

The plans and strategies should be reviewed at least every 6 years.

Marine Strategy Framework Directive: The environmental pillar for the integrated policy defined by the Maritime policy is the Marine Strategy Framework Directive (MSFD). The MSFD outlines a transparent, legislative framework for an ecosystem-based approach to the management of human activities which supports the sustainable use of marine goods and services. The overarching goal of the Directive is to achieve "Good Environmental Status" (GES) by 2020 across Europe's marine environment.

The MSFD establishes four European Marine Regions, based on geographical and environmental criteria. The North East Atlantic Marine Region is divided into four sub-regions. Each Member State is required to develop a marine strategy for its waters, in coordination with other countries within the same marine region or sub-region. This coordination must be achieved through the Regional Seas Conventions, the OSPAR and HELCOM Conventions.

The MSFD is complementary to, and provides the overarching framework for, a number of other key Directives and legislation at the European and national level. Examples include the EC Habitats Directive, the EC Birds Directive, the EU Water Framework Directive, the Common Fisheries Policy and national acts. It also helps to fulfil international commitments undertaken at the World Summit on Sustainable Development and under the Convention on Biological Diversity and the OSPAR and/or HELCOM Conventions.

The integration of the ecosystem approach into the sector legislation and management is a bottom up rather than a top down process: The Habitats Directive operates with a list of sites of Community importance, the Birds Directive with most suitable territories for birds and the CFP has to ensure that the negative impacts of fishing activities on the marine ecosystem are minimised. This is a sector interpretation of the ecosystem ap- 
proach. It has not been discussed or evaluated in a broader, holistic discussion of the relevant ecosystems on conservation and sustainable use. However, it could be important input to such discussion.

The SWOT table below is an example of strengths and weaknesses of the interpretation in a bottom up system as in the Habitats Directive, Birds Directive and the CFP. One may conclude that the MSFD will only be complementary to this legislation and will be an important input to a holistic ecosystem management.

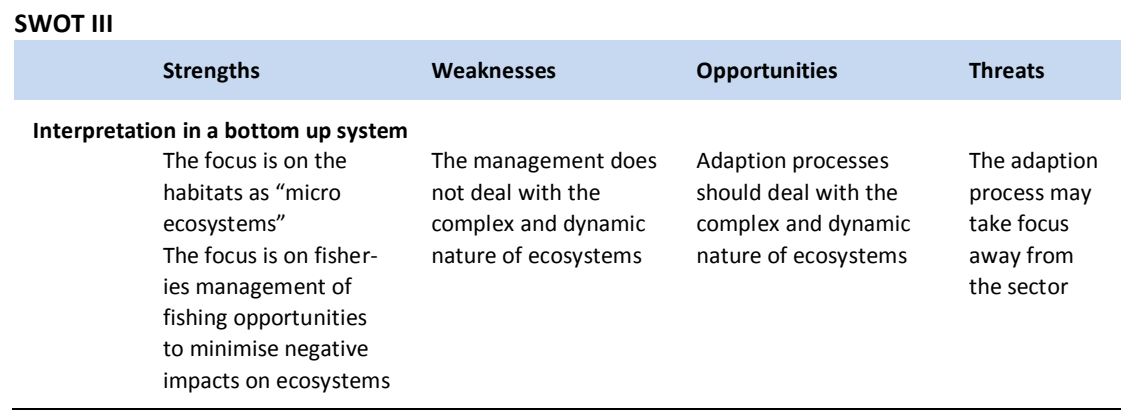




\section{Strengths and Weaknesses}

\subsection{Natura 2000 process for the Dogger Bank sites}

Experience with the Dogger Bank process revealed a number of problems related to who the legitimate participants in the MSP process are and what their roles are. Participation is based on legitimate interests e.g. Denmark was invited to the Dogger Bank process, although the country had not and did not have any intention of designating a Natura 2000 site on the Dogger Bank. The stakeholders were drawn from the North Sea RAC and in particular from its working group on Marine Spatial Planning. Stakeholders were not in all cases committed, e.g. there is currently a limited NGO response to ongoing Natura 2000 designation processes. The scale of MSP suggests that in many cases the local interests should be directly represented - which is difficult; RACs and national organisations are not always sufficient. Getting consensus is made difficult because there are several other routes open to stakeholders to influence the process (the development process, national parliaments, governments, the Commission and the European Parliament).

Although wide stakeholder representation was sought, the energy industry in particular was only represented in an observer capacity and did not fully participate in the process. This was felt by some parties to be a significant drawback. The roles of the industry, NGOs, science, and governments are imprecisely defined and the industry has asked whether the role of all stakeholders is identical. The interest that is invested also differs between the stakeholders.

Another issue is the role of ICES to provide the scientific background for MSP in international waters. At the workshop 22-23 October 2013 in Denmark ICES indicated that the organisation wanted to keep at arm's length from the MSP process. ICES sees its role as a data provider and advisory body, but not as a participant in the process. This raises the concern as to where the MSP process gets proper support for the interpreta- 
tion of data, analysis and advice. The industry also indicated that it needs access to its own scientific advisors: "Engage your own scientific competence from the start."

An analysis of the Dogger Bank process on developing fisheries measures based on stakeholder consensus suggest that the current procedure meets with two dilemmas:

- When to stop the process - What is enough?

- Information compilation and collection.

- Consensus seeking and what to do if consensus is not reached.

- Can the environment wait?

- Who are the legitimate stakeholders.

$\circ$ Everyone is invited.

- How much energy/money/time should be invested?

- Who should pay for MSP and in particular for the involvement of stakeholders?

\subsection{Strengths/Weakness/Threats/Opportunity (SWOT) Analysis}

Under this heading we present a SWOT analysis for the process of defining fisheries measures in Natura 2000 sites where stakeholders from several countries are affected, typically for fisheries, where the CFP access rules gives fishers from different countries access to operate. At the low end of the geographical scale we do not address local issues where only a single State and stakeholders in this country are concerned.

The SWOT analysis identifies the strengths, weaknesses, opportunities and threats facing an organisation in pursuing its objective. Here we focus on the structures and procedures that governments and NGOs are constrained by in their search for acceptable regulations in Natura 2000 sites. The aim is to identify the internal and external factors that are favourable and unfavourable to achieving these objectives with the aim of introducing changes in the structures and procedures that address the threats, remove the weaknesses building on the strengths of the organisation and using the opportunities that are available to the organisations. A SWOT 
analysis measures strengths etc. in the perspective of the environment in which the organisations operate. Thus a strength in one situation may be a weakness in another.

The previous chapters established the framework for the StrengthWeakness/Opportunity-Threat (SWOT) analysis by proposing answers to:

- Which criteria should good governance meet?

- What is the administrative/political model that the procedures work within?

- What constitutes an efficient and effective procedure?

- What is the legal framework that Maritime Spatial Planning works within?

Most fisheries are regional or local, so environmental concerns about the impact of fisheries should be addressed at this scale. This includes conservation of habitats and sea birds. Some sea birds which are impacted by fisheries make very long migrations, but in terms of the specific regulation of a fishery the scope is regional, although often the national scale is too limited. Thus, fisheries problems for the EU fleets, with the exception of tuna fishing, can largely be considered inside either the EU family or perhaps extended by only a few countries outside the EU, typically Iceland, Norway and the Russian Federation, as well as the Faroe Islands and Greenland. In this context the EU plays a dominant role.

The model for regulating fisheries when there are nature conservation concerns at stake includes:

- a legal basis (Habitats and Birds Directives, national legislation)

- a framework for cooperation e.g. through the regional environmental organisations (e.g. OSPAR, HELCOM ASCOBANS, NAMMCO)

- development of fisheries regulations involving stakeholders (ACs and national stakeholders)

- Scientific basis established either nationally or coordinated through ICES. 
The methodology for assessing fisheries impact in Natura 2000 sites is described by the N2K group. ${ }^{45}$

The maritime sectors and the marine environment are regulated by several directives, regulations and national legislation with sector specific objectives that are defined in different biological units and with different regional scope of the legal basis. A key strength of the current setup is that the regulations are implemented under well-established laws and transparent administrative procedures. Legal possibilities exist for improved transparency. This is also the case for the N2000 process where the legal framework in the form of the Natura 2000 programme focuses on which goals to pursue. These goals are also relatively limited, addressing small areas and ecosystems, compared to the large ecosystems such as the entire North Sea or Bay of Biscay.

A strength is that the legitimate stakeholders are well defined and that these stakeholders have worked together e.g. in the AC framework and there is therefore a good knowledge of the positions among the participants in the process. The environmental, fisheries and consumer interests are represented in the ACs. The ACs operate within fisheries policy and they provide advice in processes that involve fisheries. Furthermore, on the group dynamic level the players know each other, which is another strength. The anchorage of the Advisory Councils in the Common Fisheries Policy could be one answer to the question as to how to organise stakeholder interests in the marine ecosystems in a broader context than fisheries.

The stakeholder forums are well defined in fisheries (e.g. ACs) and there are well defined practices for stakeholder involvement in the environmental processes. However for other issues than fisheries there is no comparable structure to the ACs that assures stakeholder influence. Stakeholder input to the processes is advisory. Stakeholders are represented through the AC system as we are dealing with fisheries. One important strength of the AC system is that it is anchored and institutionalised within the EU legislation. However, the AC secretariats are weak (lim-

45 THE N2K GROUP 2012. Common methodology for assessing the impact of fisheries on marine Natura 2000. 6. November 2012 European Economic Interest Group ATECMA. 
ited staff) and the discussions between environmental and fisheries interests may not result in firm recommendations.

The present setup has suffered from an uncertain legal basis because of the reform of the CFP that entered into force in 2014 and because the co-decision procedure involving the European Parliament and the Council of Ministers evolved during the Dogger Bank process. The process took advantage of the expertise in the ICES Secretariat and in the ICES science community, but did not use the opportunities that may be available to the process by involving the regional environmental international organisations (OSPAR).

The AC system matches the scale of ecosystem/regions and could be the forum to seek stakeholder consensus in ecosystem issues in the Northeast Atlantic Ocean. If the ACs are to be the forum to cover stakeholder interests in a marine ecosystem/region, we need to clarify the strengths and weaknesses and of the ACs. These are presented below.

\section{SWOT IV}

\begin{tabular}{|c|c|c|c|}
\hline Strengths & Weaknesses & Opportunities & Threats \\
\hline \multicolumn{4}{|l|}{ (Regional) Advisory Councils } \\
\hline $\begin{array}{l}\text { The ACs are } \\
\text { establish by EU } \\
\text { legislation and are } \\
\text { arenas for stake- } \\
\text { holder groups to } \\
\text { deliberate and } \\
\text { make recommen- } \\
\text { dations on EU } \\
\text { fisheries manage- } \\
\text { ment strategies } \\
\text { Environmental } \\
\text { NGOs provide } \\
\text { input in particular } \\
\text { to the environ- } \\
\text { mental processes }\end{array}$ & $\begin{array}{l}\text { Weak secretariats } \\
\text { Not all stakehold- } \\
\text { ers feel that they } \\
\text { are heard, so the } \\
\text { commitment to } \\
\text { the process is } \\
\text { weakening }\end{array}$ & $\begin{array}{l}\text { Can look at the } \\
\text { bigger picture and } \\
\text { form alliances } \\
\text { rather than fight } \\
\text { each other } \\
\text { Delegate man- } \\
\text { agement power to } \\
\text { the ACs or similar } \\
\text { organisation (US } \\
\text { experience) } \\
\text { Creating realistic } \\
\text { expectations on } \\
\text { influences }\end{array}$ & $\begin{array}{l}\text { Vacant seats } \\
\text { amongst other } \\
\text { interest group in } \\
\text { the AC } \\
\text { NGOs and small } \\
\text { scale sector have } \\
\text { difficulty in paying } \\
\text { for participation } \\
\text { Are the NGOs } \\
\text { losing public } \\
\text { support? } \\
\text { Radicalisation of } \\
\text { the NGOs and the } \\
\text { industry - a } \\
\text { general trend in } \\
\text { society - Do NGOs } \\
\text { measure them- } \\
\text { selves against } \\
\text { Greenpeace? }\end{array}$ \\
\hline
\end{tabular}

A SWOT analysis of the process for defining fisheries measures based on environmental concerns might look as presented below. 

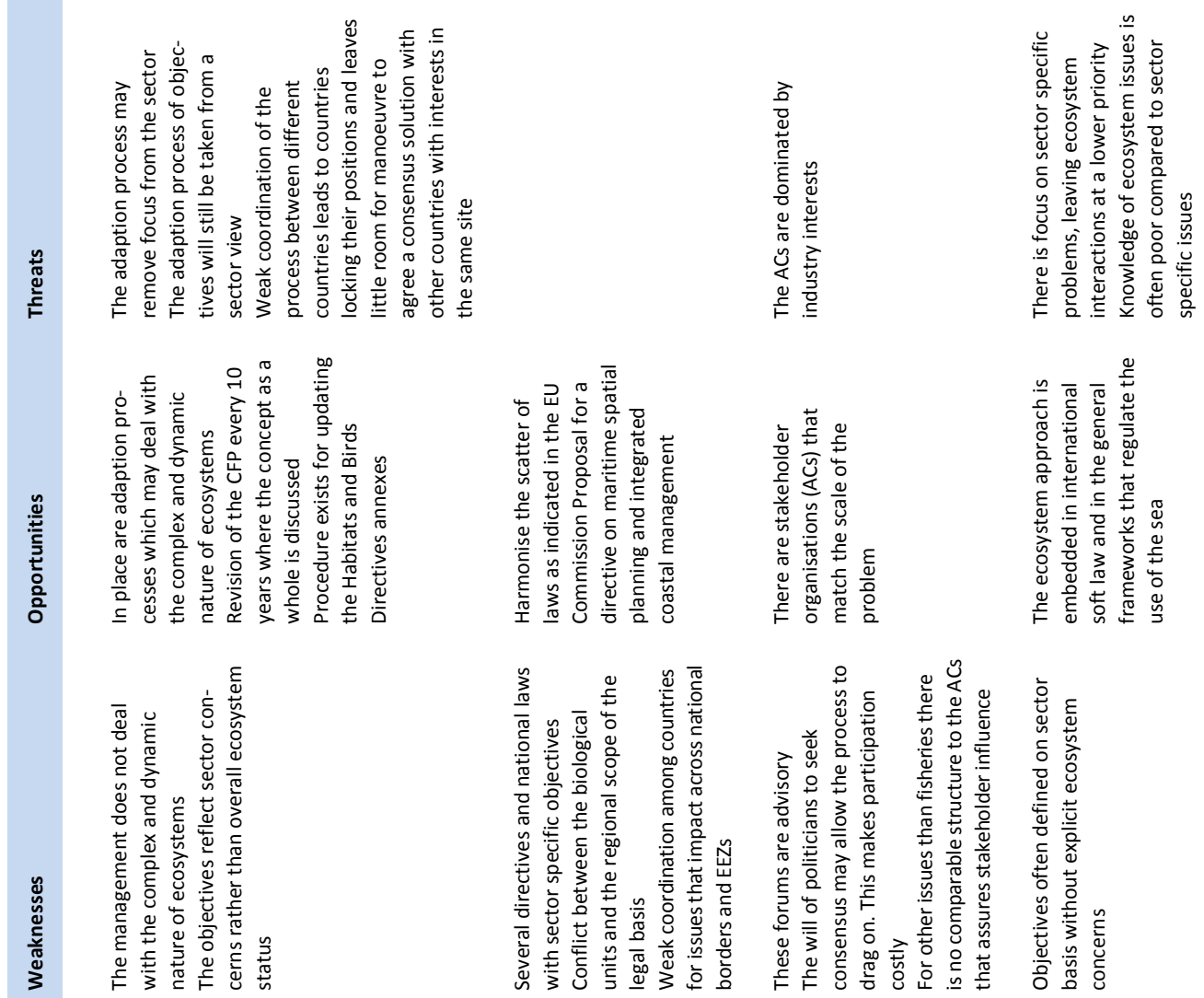

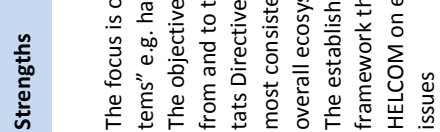
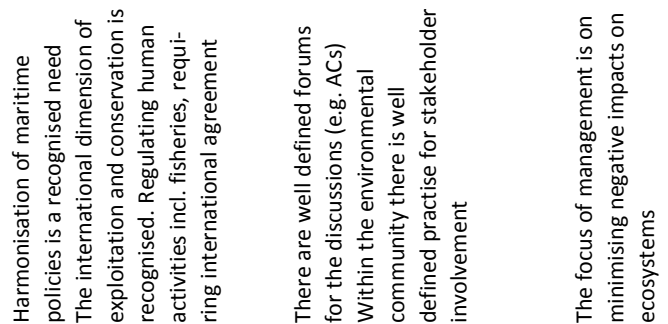

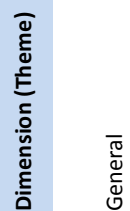
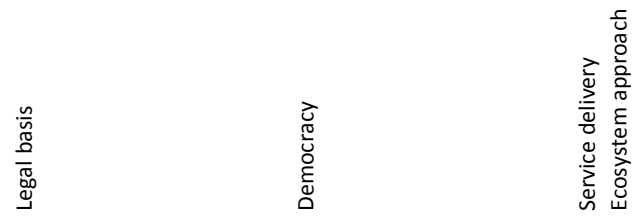

ว 

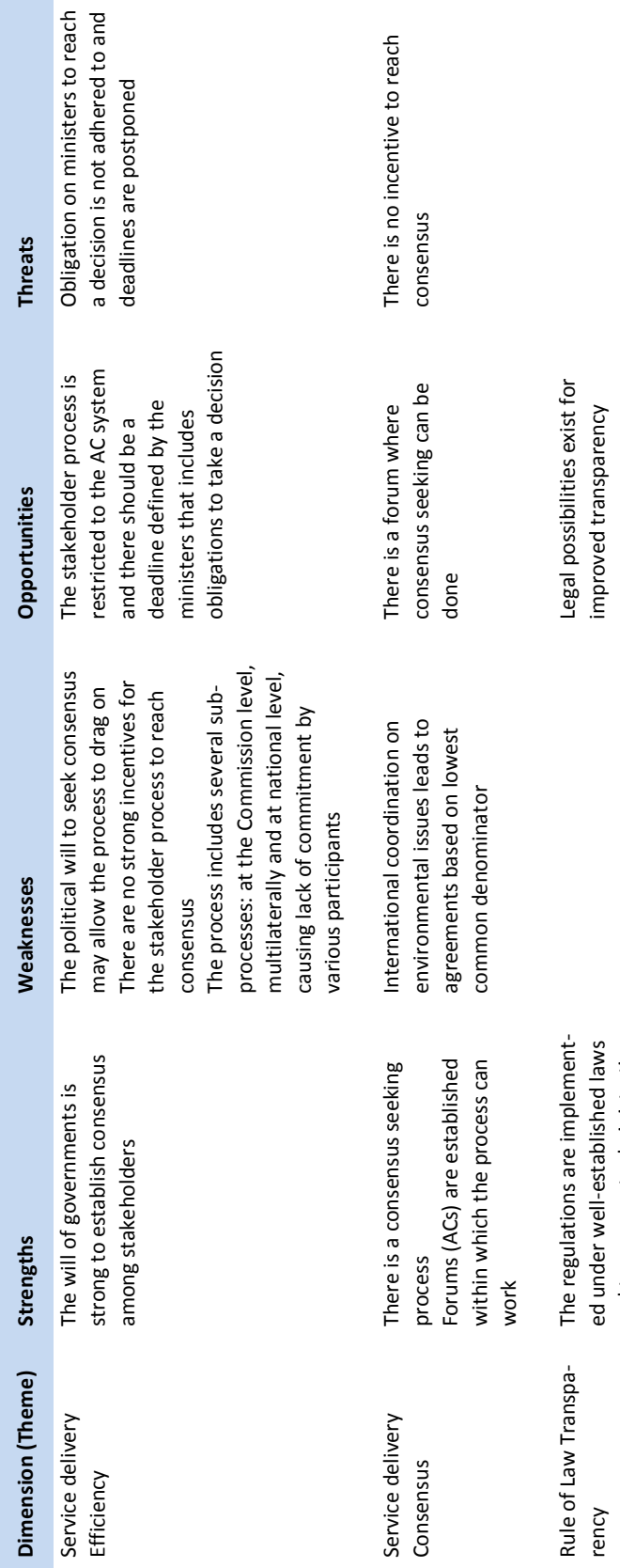



\section{Strengthening the Process for defining Fisheries Measures to meet Environmental Concerns}

Fisheries, sea transport, energy production at sea (e.g. wind farms and in the more distant future wave energy plants) and aquaculture require space and the demand on marine space is increasing. Maritime Spatial Planning will be common place and will raise similar issues as were experienced with the Natura 2000 programme and we can learn from the experience gained in the Natura 2000 programme. An example from the Belgian coast ${ }^{46}$ showed that the combined claims from all sectors required $260 \%$ of the available sea area and this illustrates the need for the planning process. For such a process to be efficient this involves a range of stakeholders. In all these uses there are concerns about the status of the environment and they must be addressed. There is an ongoing dispute between fisheries and environmental concerns world-wide. Van Hoof et al. (2011) analyse the tensions within the EU between the fisheries and the environmental concerns. ${ }^{47}$ The

\footnotetext{
46 Maes, F., Vanhulle, A., Lescrauwaet, A.K., 2013. Marine Spatial Planning. In: Lescrauwaet, A.K., Pirlet, H., Verleye, T., Mees, J., Herman, R. (Eds.), Compendium for Coast and Sea 2013: integrating knowledge on the socio-economic, environmental and institutional aspects of the Coast and Sea in Flanders and Belgium. Oostende, Belgium, p. 261-273. Marine Spatial Planning.

47 Van Hoof, Luc and Jan van Tatenhove, 2009. EU Marine policy on the move: The tension between fisheries and maritime policy, Marine Policy, 33 (4), pp. 726-732.
} 
UN-IOC provides a guide to the MSP process. ${ }^{48}$ However, this guide only very generally addresses the procedural problems that have been pointed out in this report.

These issues are:

- National planning is inclined to consider issues from the perspective of the national zone rather than from an ecosystem perspective.

- Lack of procedural instruments to bring the discussions forward, e.g. how to avoid the filibuster tactics from e.g. stakeholders.

- Coordination of timing when to address problems between countries that share problems or are being influenced by decisions in each other areas.

- Bringing the regional environmental organisations and other relevant civil society organisations into the process (in accordance with MSP guidelines) including regional organisations to provide the logistics.

Proposals for improving the process include a list of issues:

- International coordination.

- Coordination between countries should take place at the earliest possible stage in regional organisations.

- Make more effective use of the international organisations (ICES, ITC/Biodiversity, BGIF) ${ }^{49}$ for creating databases (access to data) and coordination of data analysis. The weaker the scientific basis, the greater the need for democratic debate solutions to ensure that decisions are not contested.

- Introduction of a single-stringed system structuring the national and international processes based on commitment from all participants.

○ The procedure should be divided into four sections: bringing the issue onto the political agenda, the scientific advice, stakeholder

\footnotetext{
${ }^{48}$ Ehler, Charles, and Fanny Douvere. Maritime Spatial Planning: a step-by-step approach toward ecosystem-based management. Intergovernmental Oceanographic Commission and Man and the Biosphere Programme. IOC Manual and Guides No. 53, ICAM Dossier No. 6. Paris: UNESCO. 2009 (English).

49 Global Biodiversity Information Facility http://www.gbif.org/
} 
involvement and agreement on measures. These should be welldefined phases in the process. Furthermore, there should be an integrated environment-fisheries process including an integrated scientific analysis. These should be well-defined phases in the process. This procedure is currently conducted three times before a management decision is finally taken (in the form of a delegated act adopted by the Commission on the request from Member States involved). Firstly, at national level, including consultations with neighbouring countries (off shore areas), secondly at EU level and thirdly again at national level/in fisheries at regional level.

- Adoption of timeframe and mechanisms that ensure that deadlines are adhered to.

- Involvement of stakeholders.

- The present system includes few incentives to reach consensus and the process needs to be redefined to increase the pressure on the participants to reach consensus.

- Involvement of all stakeholders should be organised by extending and adjusting the existing Advisory Councils (ACs) to the new singlestringed system.

- The funding at different stages, including funding of the involvement of science and of stakeholders should be reconsidered and compared to the current expenditure, time consumption and labour intensity.

- International legislation.

- The need to harmonise maritime policies is recognized, as well as the international dimension of exploitation and conservation. Regulating human activities incl. fisheries requires international agreement. The conflicts that are pointed out between fisheries and environmental legislation should be addressed.

- The single-stringed process that is proposed above should be embedded in the legal framework.

The elements of an improved procedure with comments are tabled below. 


\section{Box VI}

\section{Elements of an improved procedure}

\section{General}

\section{Proposals}

- MSP for offshore marine areas to be defined at the ecosystem (often international) level and lifted from the national level.

- At the start of an ecosystem approach get multilateral consensus between countries at the regional level that assures that an environmental problem is addressed in a coordinated way and at the same time in all affected countries.

- Need for single-stringed system merging the national and international process.

- The consensus should include reopening a compromise on the basis of well-defined and objective criteria (e.g. changes in ecosystem, technological changes).

\section{Comments}

- The proposed EU framework for MSP may serve this purpose.

- There are issues that involve non-EU countries and these need to be brought in early on the single-stringed process to assure commitment to the process from all participants.

- The existing regional organisations to play a central role in harmonising different national approaches and providing the logistics for the process.

\section{Service delivery}

\section{Proposals}

- Strengthen the national obligations to the regional organisations both in terms of defining the issues and in respecting the agreements.

- Define timeframe and mechanisms that assure that deadlines are adhered to.

- Restrict the process to the stakeholders and countries with real interests.

- The industry sectors to integrate in a better way the ecosystem approach into their policies. Such an integration leaves room for an integration according to the own internal logic of the sectors. 


\section{Comments}

- Respecting deadlines requires that non-agreement is an inferior option compared to possible compromises. Accept up front that revision clauses based on updated information are an integral part in the compromise. There are outstanding issues such as if and when the European Commission is entitled to take the decision, and when third countries should be involved.

- Clearly, size matters. A holistic organisation e.g. UNGA may be inefficient where a sector oriented can isolate issues and restrict participation to sector-based organisations. However, decisions may be contradicting decisions in other sectors.

\section{Rule of law}

\section{Proposals}

- Legal obligation at international level: if one country initiates a N2000 activity or similar (MSP) for a particular habitat type, this initiates a round that obliges other countries sharing the same sites/habitat type to consider the need for action - this is equivalent to land-based nature reserves that are crossed by national borders.

\section{Democracy}

- Invoking stakeholders at international level.

- Decisions at the national parliaments/governments/European Parliament as appropriate.

- Open access to data and to expertise are central issues in a democracy context.

- Stakeholder dialogue should be institutionalised across sectors in order to promote mutual understanding and trust.

- Consider funding at different stages, including funding the involvement of stakeholders. 


\section{Comments}

- Within EU fisheries the Advisory Councils (ACs) are institutionalised regional stakeholder organisations. Consider if the mandate of ACs could be expanded.

- Assuring that all relevant stakeholders (e.g. including energy production industry) are involved.

- There is public support for the functioning of the ACs.

- Clearly, size matters. Addressing a problem at the global level, e.g. UNGA may be inefficient as at this scale.

- A long list of NGOs feel that they should have an input, making the process costly.

\section{Data and Science}

\section{Proposals}

- Effective use of the international organisations (ICES, ITC/Biodiversity, BGIF) for creating databases (access to data) and coordination of data analysis.

\section{Comments}

- BaltSeaPlan recommends moving away from the idea of an allencompassing data collection to be replaced by a decentralized system based on a network of data providers, which align their data according to the given data infrastructure.

\subsection{International legislation and coordination: Proposal for a Single-stringed system}

There is a legal obligation at international level to coordinate with neighbouring countries when a country initiates a N2000 activity or similar (MSP) for a particular habitat type that is shared with other countries. Together they have to consider the need for action - this is equivalent to land-based nature reserves that are crossed by national borders. However, such coordination takes place at a stage when the national designation has already taken place. It might end up being a very complicated process 
if the involved countries do not share concerns for the habitat type. The mechanisms that ensure coordination between countries are weak. EU legislation requires that consultation takes place, but there is no requirement for the national processes to be parallel in time although where fisheries are involved, measures are introduced on the basis of the CFP and this requires jointly agreed measures. Weak coordination of the process leads to countries locking their positions and this leaves little room for manoeuvre to agree a consensus solution with other countries with interests in the same site. Moreover, the environmental standards for good environmental status are only defined in broad terms and only provide weak guidance.

The need for harmonising the scatter of laws is pointed out in EU Commission's Proposal for a directive on maritime spatial planning and integrated coastal management. The starting point for such a harmonisation should be the concern for the marine ecosystem. There is general consensus between the EU countries ecosystem on this point. Harmonising should work at the ecoregion, i.e. at regional level and make sure that an environmental problem is addressed in a coordinated way and at the same time involving all countries affected, including non-EU countries.

We consider that the process needs to be simplified and replaced with what may be called a "single-string approach." The process should be based on a well-defined set of rules and we propose to give the international environmental organisations and fisheries organisations a role as central partners in the process. This requires a strengthening of the international organisations so that they can become more proactive in pushing the process forward. Trans-boundary cooperation should be facilitated in a regional context where a regional organisation (OSPAR/HELCOM) on the basis of the Marine Strategy Framework Directive and Maritime Spatial Planning could contribute and further and complete the process from the large scale ecosystem angle. Thus the process would reflect not only the concerns of the sectors, but the status of the overall ecosystem as well. A central discussion platform might make it easier to deal with the complex and dynamic nature of ecosystems a discussion that obviously needs a holistic rather than a national approach.

An element in the decision process is the scientific advice. The scientific advisory process could also be improved. The process with respect to 
fisheries is well organised involving STECF and ICES. On the environmental side there is no EU committee corresponding to the STECF and it seems that ICES is partly filling this role. Also, the Commission Directorate General "Joint Research Centre" plays a role, as do a number of university institutes and e.g. the European Topic Centre on Biological Diversity are all involved. On the practical level there is some degree of coordination, but the process is far from clear. The roles could be better defined. Open access to data and to expertise is a central issue in a democracy context. An environment with effective use of the international organisations (ICES, ITC/Biodiversity, BGIF) ${ }^{50}$ for creating databases (access to data) and coordination of data analysis should be strengthened.

The current procedure includes four sections: acceptance of bringing the issue onto political agenda, the scientific advice, stakeholder involvement and agreement on measures. These should all be well-defined phases in the process. Furthermore, the environmental and the fisheries processes run separately. Presently, the procedure is carried out three times before a fisheries management decision is finally taken (by means of a delegated act by the Commission on the request from Member States involved). Firstly, at national level, including consultation with neighbouring countries (off shore areas), secondly at the EU level and thirdly again at national level/in fisheries at regional level.

The proposed single-stringed system should structure the national and international processes; this should integrate the fisheries and the environmental processes and there should be an integrated scientific analysis. The overall aim is to avoid the repetition of the steps. The procedure should maintain the current four sections as well-defined phases in the process: acceptance of bringing the issue onto the political agenda, the scientific advice, stakeholder involvement and agreement on measures. Furthermore, there should be an integrated environment-fisheries process and this should not be separate. The singled-stringed process should be based on commitment to the process by all participants.

${ }^{50}$ Global Biodiversity Information Facility http://www.gbif.org/ 
A key factor in streamlining the system is to work with milestones based on the adoption of a timeframe assuring that when a milestone is reached, there is no going back and no reopening the issue. However, it is very difficult to construct mechanisms that assure that deadlines are adhered. We must create a situation when non-agreement is an inferior option compared to possible compromises, but we are short of proposals as to how to construct this situation. The most important is that all participants are committed to a revised procedure.

The funding of the process at different stages, including the funding of involvement of stakeholders should be considered. The proposed EU framework for MSP may serve this purpose.

An important element in the system is that reopening a compromise should be based on well-defined and objective criteria (e.g. changes in ecosystem, technological changes) as part of the legal framework.

\subsection{Involvement of stakeholders}

Within EU fisheries the Advisory Councils (ACs) are institutionalised regional stakeholder organisations. There is public support for the functioning of the ACs. The mandate of ACs could be expanded to include and involve all relevant stakeholders (e.g. including energy production industry). The AC system matches the scale of ecosystems/regions and could be the forum to seek stakeholder consensus in ecosystem issues in the EU part of the Northeast Atlantic Ocean.

However, we think that the formally established ACs match the scale of the problem. The stakeholder process should be done through the AC system, and ACs should be the forums where consensus seeking can be done. The AC system should include strong incentives to reach consensus. An element is the strict application of deadlines and that includes obligations on government to make a decision even if the stakeholder advice is not forthcoming. Another element may be that the current domination by industry interests could be reconsidered.

There is not always unified stakeholder input to the process. The lack of commitment by various stakeholders may be due to the fact that there are no incentives for the stakeholder process to reach consensus within the ACs. 
However, the politicians still will seek consensus between the environmental advice and the industry advice and may allow the process to drag out. The obligation for ministers to reach a decision is not adhered to and deadlines are postponed. To participate in a prolonged process is costly.

\subsection{Concluding remarks}

The EU environmental legislation requires member states to take action to organise and implement trans-boundary cooperation. Good governance calls for consensus seeking among stakeholders and the Dogger Bank case demonstrated that governments are going to great lengths to facilitate this process both by direct support to the stakeholder process and allowing liberal time for the process to run. Even so, in spite of very significant efforts, the NSRAC did not provide a consensus proposal with all stakeholders behind it. However, because of government commitment to establish a Natura 2000 network also in the marine area, the process was brought forward. This illustrates that at the end of the day, the politicians have to prioritise the inputs and take a decision. The stakeholders are very well aware of this fact and parallel to the international process will establish other processes, both multilaterally and at national level together with the standard lobbying work aimed at influencing the Commission, the European Parliament and national decision makers. This complicates and delays the development process. It is because of these tactics that the procedures and processes need to be cleared up, made simpler, and require a single-stringed process. The argument is not only for a singlestringed process, but for a process with sufficient power to make participants adhere to the rules. This is the basic line of thinking behind the proposals for improvements.

The proposal for improvements suggests that the regional organisations should be given a stronger role in the framework and we have pointed to the regional organisations e.g. OSPAR and HELCOM. This is an attempt to respect the regional aspects of the regulations. Those who are affected are nearly always regionally confined. The regional organisations are of limited size involving only those governments that are affected. For most issues we find that the role of global organisations does not go beyond defining very 
general objectives. The regional and global international organisations ought to cooperate in creating an efficient solution.

MSP for offshore marine areas should be defined at the ecosystem (often international) level and lifted from the national level. But there is a balance to strike and in this case a sector oriented approach can isolate issues and restrict participation to sector-based organisations and in the end make decisions with a much better understanding of the sector issues, whereas a general approach will have many more difficulties in handling the clearly much greater amount of information that is relevant. However, sector based decisions may contradict decisions in other sectors.

As argued above, in cases where data and other scientific evidence, scientific advice and stakeholder input are clarified at the earliest possible stage of the process, this will pave the way for a faster, cheaper and less time consuming process and perhaps even greater commitment to the results.

Linke and Jentoft ${ }^{51,52}$ advocate that the ACs are not well designed for transferring responsibilities to stakeholders and argue that the burden of proof on responsible fisheries should be shifted to the ACs as a precondition for giving them more management responsibility. Under a changed setup of responsibilities, the main role of government is to control the environmental impact of the fisheries. Reversing the burden of proof is further discussed by Lassen et al. (2008). ${ }^{53}$

The proposed elements of an improved procedure can only be introduced after a longer public debate. The proposals touch on national sovereignty and in general advocate that offshore issues cannot be addressed on the basis of national concerns alone. These points of view are not in fashion in present politics.

\footnotetext{
51 Linke Sebastian, and Jentoft Svein, 2013. Exploring the phronetic dimension of stakeholders' knowledge in EU fisheries governance. Marine Policy, http://dx.doi.org/10.1016/j.marpol.2013.10.010i

52 Linke Sebastian and Jentoft Svein, 2012. A communicative turnaround: Shifting the burden of proof in European fisheries governance. Marine Policy 38 (2013) 337-345.

${ }^{53}$ Lassen Hans, Sissenwine Michael, Symes David and Thulin Jan, 2008. Reversing the burden of proof for fisheries management: Managing commercial fisheries within sustainable limits. A SAFMAMS Workshop held at ICES Secretariat Copenhagen, Denmark 4-5 March 2008.
} 
Many countries may prefer to stick to the existing procedures. Most environmental legislation has and will leave room for exceptions to ensure public interests (birds and air traffic, relocation of habitats for sea port expansion, defence). Furthermore, the current procedures leave space to national prioritisation of marine areas to protect, conserve or exploit natural resources, not only within the territorial sea inside $12 \mathrm{~nm}$, but also outside $12 \mathrm{~nm}$ in the whole exclusive economic zone. The prioritisation between different exploitation interests and between exploitation and environmental concerns is taken at national level, and environmental concerns are integrated in the sector policies.

There are environmental concerns which should be dealt with within large regional ecosystems. In the Dogger Bank process the lack of discussion at national level on Dogger Bank as a sand bank ecosystem was discussed at the later stage when fisheries measures were discussed. The question on the role of the Dogger Bank in the larger North Sea ecosystem was never raised, perhaps because it does not play any major role in the North Sea. Thus the Dogger Bank process does not take into account any effects on the North Sea ecosystems outside the Dogger Bank.

The current legislation does not seem to include any obstacle to shortcutting the process at the initial stage of the designation process to gathering all data input, including input from stakeholders, scientific advice and the involvement of stakeholders.

In the Baltic Sea the need for a regional platform is recognised and HELCOM in accordance with the philosophy of MSFD has initiated a joint programme to remedy the deficiencies that were seen in the Dogger Bank process. The BaltSeaPlan is approaching the problems directly by looking at 8 pilot areas in which to develop marine spatial plans, ${ }^{54}$ but closely following the procedure laid down in the N2K document. BaltSeaPlan recognises the scope of the procedural problem asking as its first principle planners to take a pan-Baltic perspective regarding the Baltic Sea as one ecosystem at all stages of the MSP process. BaltSeaPlan recommends moving away from the idea of an all-encompassing data collection to be re-

54 http://www.baltseaplan.eu/index.php/Home;1/1 
placed by a decentralised system based on a network of data providers, which align their data according to the given data infrastructure.

We realise that implementing changes will meet with substantial problems because of the fundamental differences in the legal approaches both between countries and between environmental and fisheries issues. The proposals presented aim at stronger coordination between countries and this raises the possible issue of transfer of sovereignty to international level. However, such transfer may be necessary to 1) address the issues at the proper scale, 2) assure a level playing field for all interested parties including control and enforcement, and 3) provide a transparent process when establishing and revising the regulations. The subsidiarity principle - regional or national approaches - may be in good accordance with the ecosystem approach. 



\section{Sammenfatning}

TemaNord rapporten analyserer stærke og svage sider i de procedurer, der gælder, når fiskeriforvaltningstiltag skal træffes i off-shore marine beskyttede områder, i EU i de såkaldte Natura 2000 områder. Rapporten fokuserer på fiskeriregulering i Natura 2000 områder i den eksklusive økonomiske zone (uden for $12 \mathrm{~s} ø \mathrm{mil}$ ), idet områder inden for 12 sømil involverer flere interesser, hvilket komplicerer problemstillingen væsentligt.

Formålet med rapporten er at initiere en debat, der fører til bedre regeringsførelse, når fiskeri skal reguleres i Natura 2000 områder.

Rapportens tilgang til beskyttelse af havmiljøet er økosystemtænkning, hvor udgangspunktet er en holistisk integreret tilgang af de marine økosystemer, navnlig bevarelse af biodiversitet.

Som eksempel på menneskelige aktiviteter i det marine miljø bruger rapporten EU's regulering af fiskeri i Natura 2000 områder. Natura 2000 processen begynder nationalt, efterfulgt af en koordinering med nabolandene i stedet for at begynde med en koordineret drøftelse af det samlede økosystem. Rapporten konkluderer, at de gældende procedurer er tidskrævende, dyre og ineffektive og foreslår en ny og mere strømlinet proces, som samtidig styrker dialogen mellem interessenterne. Hovedeksemplet i rapporten er processen, hvor tre EU-lande har udpeget Natura 2000 områder i deres del af Dogger Banke med henblik på gunstig bevaringsstatus. De tre lande er enige om at begrænse fiskeri med bundslæbende fiskeredskaber for at undgå forringelser af sandbanken og følsomme arter på sandbanken. Dogger Banke processen begyndte i nullerne, men fiskerierne er endnu ikke (maj 2014) reguleret med henblik på at forbedre miljøtilstanden på banken.

Den gældende proces begynder med nationale forslag til udpegning af områder, der evalueres på EU-niveau, før man nationalt vedtager udpegningen. Den nationale udpegning følges op ved nationale forslag til fiskeriregulering i områderne. Disse forslag baseres på en koordineret analyse, der involverer andre EU-landes fiskeriinteresser i områderne. EU- 
Kommissionen er bemyndiget til at vedtage delegerede retsakter af fiskeritiltag i Natura 2000 områder. Vedtagelsen af tiltag skal notificeres til Europa Parlamentet og EU's Ministerråd og træder i kraft efter to måneder, hvis der ikke er indvendinger i disse to organer.

En af årsagerne til den langvarige proces er, at processen begynder i miljøregi, hvor miljøvidenskab og interessenter inddrages i en miljøsammenhæng. Herefter fortsætter processen i en fiskeriproces (sektor proces), der involverer fiskerividenskab og interessenter. Den information, der forelå i miljøprocessen bliver evalueret og suppleret i en fiskerisammenhæng.

En anden årsag er til den langvarige proces er, at viden om havmiljø er sparsom, og det er dyrt at fremskaffe viden om struktur og dynamik i havmiljøet. På den ene side er den sparsomme viden utilstrækkelig til at gennemføre en relevant, holdbar fiskeriregulering, og på den anden side ønsker man ikke vente med at beskytte havmiljøet til et tilstrækkelig grundlag foreligger.

Jo mere sparsomt det videnskabelige grundlag er, desto større behov er der for løsninger, der baseres på en demokratisk debat.

Den sparsomme viden må derfor suppleres med interessenternes viden samt deres holdninger til, hvordan man bedst muligt beskytter og bevarer levesteder og arter i områderne. Forhandlinger med interessenterne om løsningsforslag kan trække i langdrag, og det forsinker beskyttelsen i Natura 2000 områderne.

I rapporten undersøges den rolle, som videnskaben og interessenterne har. Videnskaben burde udgøre et fælles udgangspunkt for de efterfølgende forhandlinger mellem interessenterne. Det kræver en koordineret indsats på et så tidligt tidspunkt som muligt i processen, i stedet for som nu at flere videnskabelige grupper supplerer det foreliggende videnskabelige grundlag, efterhånden som processen skrider frem.

På baggrund af analysen foreslår rapporten forbedringer af proceduren, ved at indføre et enstrenget system, hvor man samler den videnskabelige forskning og rådgivning for udpegning og for fiskeriforvaltning $\mathrm{i}$ Natura 2000 områderne med en samlet inddragelse af interessenter.

En væsentlig fornyelse vil være etablering af den fælles platform for den videnskabelige forskning og rådgivning, hvor de foreliggende oplysninger drøftes og kvalificeres på tværs af sektorer og lande, således at der tilvejebringes det bedst mulige videnskabelige grundlag fra begyndelsen. 
Derefter inddrages interessenterne på tværs af lande og sektorer, hvor de kan bidrage med løsningsforslag. Den videnskabelige platform foreslås placeret i havkonventionerne (OSPAR og HELCOM).

Fiskeriinteressenterne er organiseret i formelle (Regionale) Rådgivende Råd, de såkaldte (Regional) Advisory Councils, der er et forum for interessenternes drøftelser af økosystem emner i Nordøstatlanten. Mandatet i de Rådgivende Råd er begrænset til fiskerispørgsmål, men mandatet kunne udvides og inddrage yderligere interessenter, så alle aspekter dækkes i det samlede økosystem/region. Det kræver, at mandat og medlemskab gennemgås og ændres, hvor der er behov herfor.

Rapporten indeholder følgende:

- Kapitel 1 vedrører baggrunden for regulering af menneskelige aktiviteter i marine områder uden for 12 sømil i Nordøstatlanten.

- Kapitel 2 beskriver rammerne for god regeringsførelse og en model for de forhandlingsrammer for processen, som der bør være enighed om, før den formelle proces om forvaltningstiltag begynder. I dette kapitel udvikles også elementer, som kan føre til mere effektive forhandlinger.

- Kapitel 3 beskriver videnskabens rolle i forhandlingsprocesserne på national og på EU niveau.

- Kapitel 4 fokuserer på definitionen af økosystemer, og det $ø$ kosystemniveau, emnerne behandles på, økosystemtilgangen og den geografiske opdeling af marine områder i EU-lovgivningen samt behovet for harmonisering.

- Kapitel 5 vedrører en analyse i form af styrker, svagheder, muligheder og trusler (SWOT) i processen for de fiskeritiltag, der skal træffes for at beskytte havmiljøet.

- Kapitel 6 er et forslag til styrkelse af processer og procedurer. På basis af SWOT analysen i kapitel 5, indeholder dette kapitel nogle elementer til at forbedre processerne og procedurerne for international regulering af menneskelige påvirkninger i Natura 2000 områder eller områder, der skal beskyttes af tilsvarende grunde.

- Bilag I præsenterer nogle centrale internationale organisationer. Bilag II-IV er en kort opsummering af den centrale EU-lovgivning, navnlig Habitatdirektivet, Fuglebeskyttelsesdirektivet, Havstrategidirektivet, 
Vandrammedirektivet og den fælles fiskeripolitik. Endelig præsenterer bilag VII Natura 2000 netværket og processen fra udpegning af områderne til regulering af de menneskelige aktiviteter.

Forslagene til forbedring i effektivitet, struktur og procedurer for fiskerireguleringer i Natura 2000 områder uden for 12 sømil (Natura 2000 i EEZ-en) ${ }^{55}$ er bl.a. følgende:

- International koordinering.

○ Koordinering mellem landene skal gennemføres på et så tidligt tidspunkt som muligt i regionale organisationer.

- De internationale organisationer bør bruges mere effektivt (ICES, ITC/Biodiveritet, GBIF ${ }^{56}$ med henblik på etablering af databaser (adgang til data) og koordinering af dataanalyser. Jo mere sparsomt det videnskabelige grundlag er, desto større behov er der for løsninger, der baseres på en demokratisk debat for at sikre, at beslutningerne ikke bestrides.

- Indførelse af et enstrenget system, der strukturerer den nationale og internationale proces, der baseres på forpligtende enighed fra samtlige deltagere.

- Proceduren bør opdeles i fire trin: Emnet sættes på den politiske dagsorden, den videnskabelige rådgivning, inddragelse af interessenter, og enighed om tiltag. Dette bør gøres i veldefinerede faser i processen. Endvidere bør der være en integreret miljø- og fiskeriproces, herunder integrerede videnskabelige analyser. Denne procedure gennemføres tre gange i den nugældende procedure, inden fiskeriregulering (på baggrund af anmodning fra de involverede lande) vedtages (af Kommissionen som delegerede retsakter): Første gang på nationalt niveau, herunder høring af nabolande (områder i EEZ-

55 Disse forslag bør også anvendes i områder inden for 12 sømil, der går på tværs af landegrænser og kystområder (indenfor 12 sømil), hvor andre lande har fiskeriinteresser.

56 Global Biodiversity Information Facility http://www.gbif.org/ 
en), næste gang på EU niveau, og tredje gang igen på national niveau/i fiskeriet på regionalt niveau.

- Vedtagelse af en tidsramme og mekanismer, der sikrer, at fristerne overholdes.

- Inddragelse af interessenter.

○ Det nugældende system indeholder få incitamenter for at nå konsensus, og processen bør omdefineres for at øge presset på deltagerne med henblik på konsensus.

- Inddragelse af interessenter bør organiseres ved en udvidelse og tilpasning af de eksisterende Regionale Rådgivende Råd (RACere) (nu Rådgivende Råd) til det nye enstrengede system.

- Finansiering af de forskellige trin i processen, herunder finansiering af inddragelsen af videnskab og interessenter bør overvejes og sammenholdes med de nuværende udgifter, tidsforbrug og arbejdsindsats.

- International lovgivning.

- Behovet for harmonisering af de maritime politikker er erkendt. Det samme gælder den internationale dimension af udnyttelse og bevaring. Regulering af menneskelige aktiviteter, herunder fiskeri, nødvendiggør internationale aftaler. De konflikter mellem fiskeri- og miljølovgivning, der er påpeget, bør adresseres.

- Den enstrengede proces, som foreslås ovenfor, bør tages op i lovgivningen.

Sådanne ændringer kan kun gennemføres på langt sigt og bør drøftes indgående i relevante fora, herunder i regionale organisationer, i interessentfora, parlamenter, forvaltningsfora og i den offentlige almenhed. 



\section{Annex I:}

\section{Central Organisations for Maritime Spatial Planning in offshore Northeast Atlantic areas}

\subsection{The European Commission}

The European Commission (EC) is the executive body of the European Union responsible for proposing legislation, implementing decisions, upholding the Union's treaties and the day-to-day running of the EU. The term "Commission" is used either in the narrow sense of the 28-member College of Commissioners, or also to include the administrative body which is split into 40 Directorates-General and Services. When considering fisheries measures in Natura 2000 offshore areas two Directorates-General are particularly involved: Directorate-General for Environment (DG ENV) and the Directorate-General for Maritime Affairs and Fisheries (DG MARE).

DG MARE manages two policy areas: (1) Integrated Maritime Policy, and (2) Common Fisheries Policy (CFP). DG MARE works to develop the potential of the European maritime economy and to secure a safe and stable supply of seafood, sustainable fisheries, healthy seas and prosperous coastal communities - for today's Europeans and for future prosperous generations. The Common Fisheries Policy is the cornerstone of actions for a sustainable exploitation of fisheries resources, while the Maritime Policy promotes an integrated approach to all maritime policies. The Commission works with the implementation of the CFP-reform, adopted in 2013 and with the Maritime Policy (proposal 1013) to contribute to sustainable growth and employment.

DG ENV is established to protect, preserve and improve the environment for present and future generations. To achieve this DG ENV proposes policies that ensure a high level of environmental protection in the Euro- 
pean Union and that preserve the quality of life of EU citizens. Maritime Spatial Planning is national competence. However, the Marine Strategy Framework Directive (MSFD) and the proposal for a framework directive on Maritime spatial planning both point to the regional organisations as the proper forums for negotiations among involved Member States when dealing with issues at the international scale. The two organisations in the North-East Atlantic including the Baltic Sea are OSPAR and HELCOM.

\subsection{OSPAR}

Figure 3 OSPAR Regions in the Northeast Atlantic Ocean (From http://www. ospar.org/). The Greater North Sea has been highlighted as this includes the Dogger Bank and where many EU Member States have interests

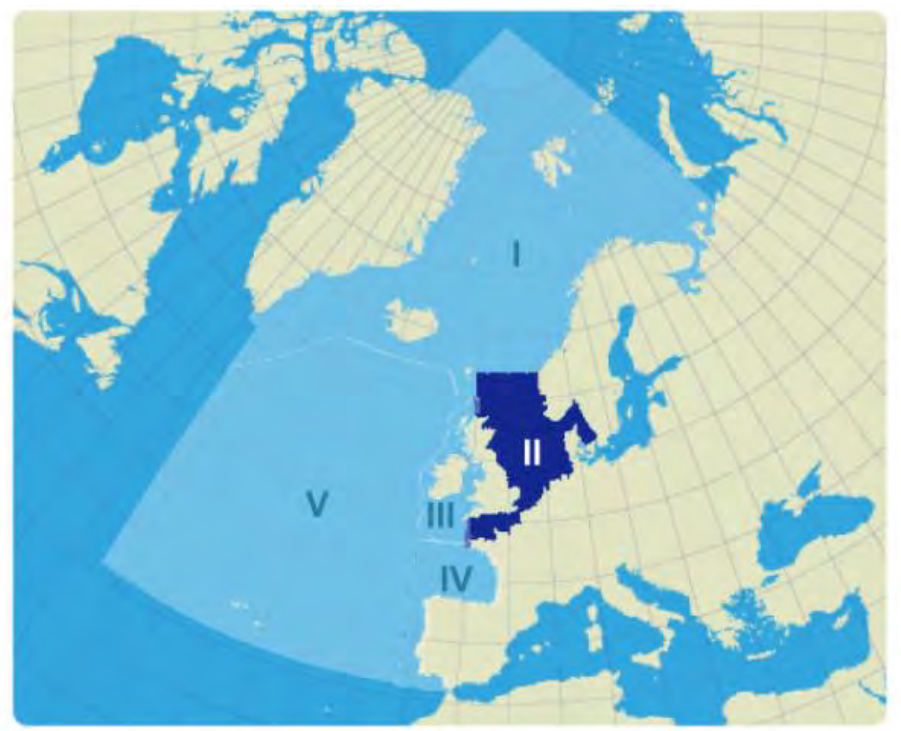

The North East Atlantic

Region I Arctic Waters

Region II Greater North Sea

Region III Celtic Seas

Region IV Bay of Biscav and lberian Coast

Region V Wider Atlantic 
OSPAR ${ }^{57}$ is the mechanism by which fifteen Governments of the western coasts and catchments of Europe, together with the European Community, cooperate to protect and conserve the marine environment of the NorthEast Atlantic. It started in 1972 with the Oslo Convention against dumping. It was broadened to cover land-based sources and the offshore industry by the Paris Convention of 1974 . These two conventions were unified, up-dated and extended by the 1992 OSPAR Convention. The new annex on biodiversity and ecosystems was adopted in 1998 to cover non-polluting human activities that can adversely affect the sea.

OSPAR distinguishes in its analyses five different subareas within its convention area, Figure 3.

\subsection{HELCOM}

\section{Figure 4 HELCOM area in the Baltic Sea and Kattegat}

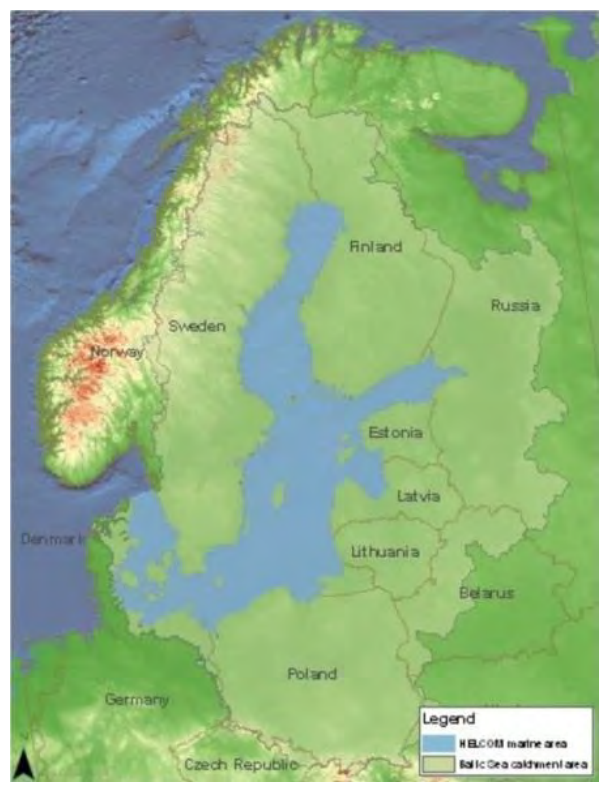

57 http://www.ospar.org/content/content.asp?menu=00010100000000_000000_000000 
The Helsinki Commission, or HELCOM 58 works to protect and conserve the marine environment of the Baltic Sea from all sources of pollution through intergovernmental co-operation between Denmark, Estonia, Finland, Germany, Latvia, Lithuania, Poland, Russia and Sweden. The organisation was founded in 1974.

HELCOM is the governing body of the "Convention on the Protection of the Marine Environment of the Baltic Sea Area" - more usually known as the Helsinki Convention.

In pursuing this objective and vision the riparian countries have jointly pooled their efforts in HELCOM, which works as:

- an environmental policy maker for the Baltic Sea area by developing common environmental objectives and actions

- an environmental focal point providing information about (i) the state of/trends in the marine environment; (ii) the efficiency of measures to protect it and (iii) common initiatives and positions which can form the basis for decision-making in other international organisations

- a body for developing, according to the specific needs of the Baltic Sea, recommendations of its own and recommendations supplementary to measures imposed by other international organisations

- a supervisory body dedicated to ensuring that HELCOM environmental standards are fully implemented by all parties throughout the Baltic Sea and its catchment area

- a co-ordinating body, ascertaining multilateral response in case of major maritime incidents.

58 http://www.helcom.fi/helcom/ 


\subsection{International Council for the Exploration of the Sea (ICES) ${ }^{59}$}

Figure 5: ICES Member Countries. Source: ICES Secretariat

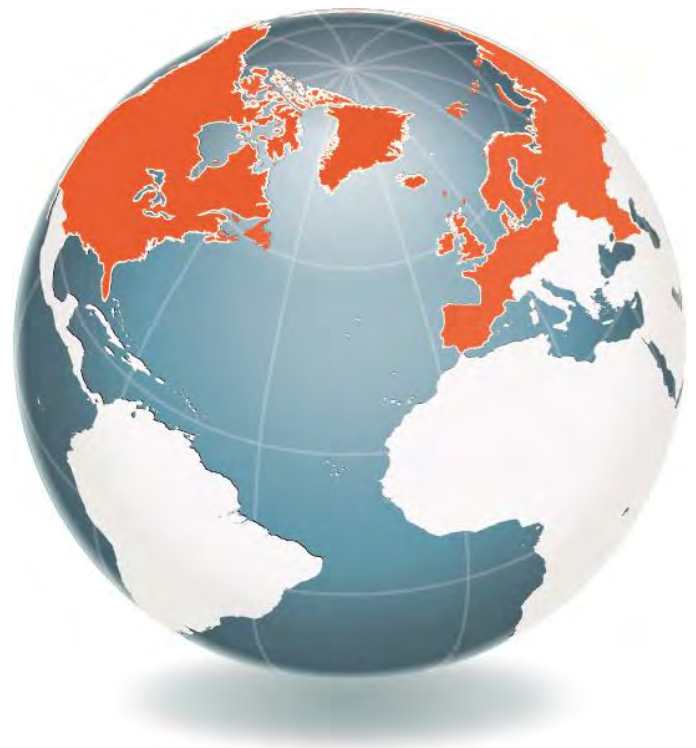

ICES is an intergovernmental organisation whose main objective is to increase the scientific knowledge of the marine environment and its living resources and to use this knowledge to provide advice to competent authorities. The ICES members are by its convention countries that have coasts bordering the North Atlantic Ocean and the Baltic Sea. ICES Science and Advice considers both how human activities affect marine ecosystems and how ecosystems affect human activities. In this way, ICES ensures that best available science is accessible for decision-makers to make informed choices on the sustainable use of the marine environment and ecosystems.

The main ICES deliverables are scientific publications and scientific information and management advice requested by member countries as well as international organisations and commissions such as the OSPAR

${ }^{59}$ Based on http://www.ices.dk 
Commission, the Helsinki Commission (HELCOM), the North East Atlantic Fisheries Commission (NEAFC), the North Atlantic Salmon Conservation Organisation (NASCO), and the European Commission (EC). Importantly, these products are unbiased, non-political in nature, and based on the best available science.

The ICES network includes more than 4,000 scientists from almost 300 institutes, with 1600 scientists participating in activities annually. ICES is therefore well positioned to compile information that is required as background for MSP in the North Atlantic Ocean and in the Baltic Sea.

\subsection{Advisory Councils}

One important type of stakeholder involvement in the Common Fisheries Policy is the formally established Advisory Councils (AC) where fishermen, vessel owners, processors, traders, fish farmers, women's fisheries groups, environmental, consumer organisations and others discuss fisheries issues and provide recommendations into CFP policy developments.

The ACs bring together people from different backgrounds and interests and thus promotes a better understanding between all groups, such as fishermen and environmental interests and the scientific community.

The ACs are established according to the Common Fisheries Basic Regulation (Articles 43-45 and Annex III of the Common Fisheries Policy Basic Regulation). They are organised in sea regions/ecosystems: Northwestern Waters AC, North Sea AC, South-western Waters AC, Baltic Sea AC, Mediterranean Sea AC, Black Sea AC, Pelagic Stocks and Long Distance $\mathrm{AC}$, Outermost regions (West Atlantic, East Atlantic, Indian Ocean) AC. The ACs provide coordinated contribution of their knowledge and experiences from their region to the EU Common Fisheries Policy.

The ACs are partly funded by the EU.

Fisheries interests comprise $60 \%$ in the ACs. The remaining $40 \%$ are from other interest groups. The ACs must promote a balanced representation of all stakeholders. The ACs must contribute to the achievement of environmentally sustainable activities in the long-term. 
Figure 6: Regions covered by EU Advisory Councils

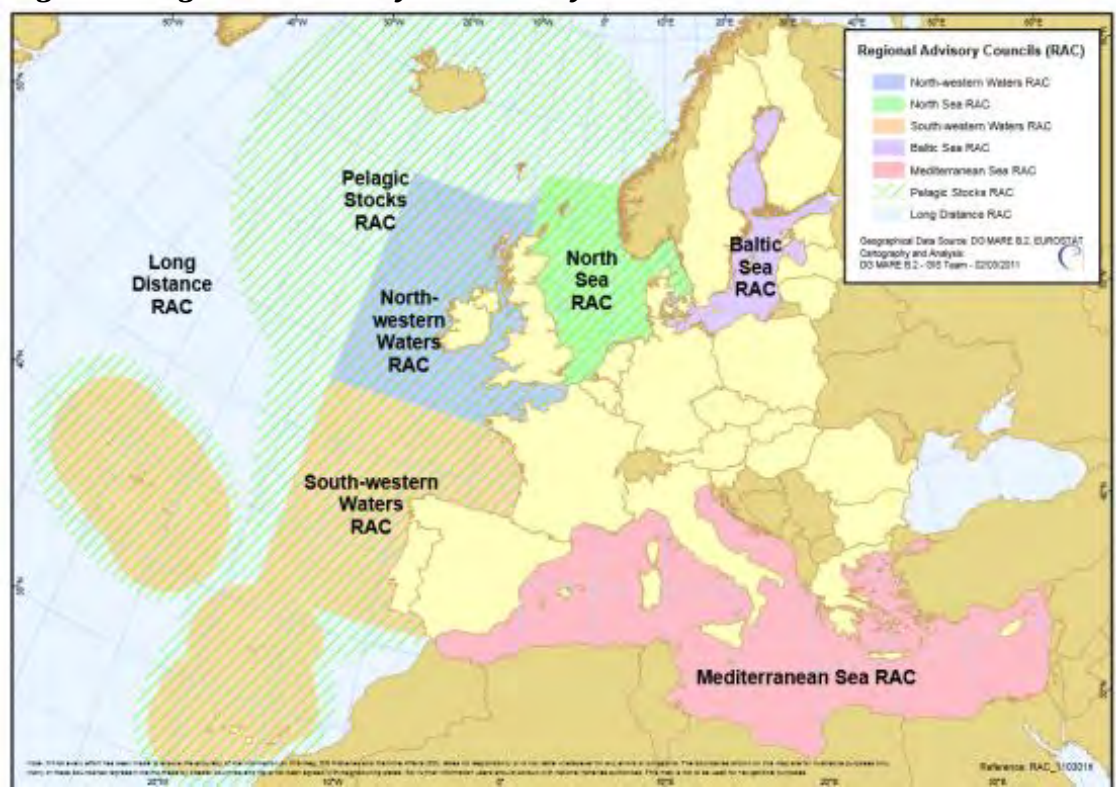

Source: European Commission

The Advisory Councils will be supplemented by Advisory Councils for Markets and for Aquaculture. 



\section{Annex II: Protection of habitats and species - EU Habitats Directive}

In 1992 the European Council adopted Council Directive 92/43/EEC on the Conservation of natural habitats and of wild fauna and flora: the socalled Habitats Directive. 60

The Directive was adopted because natural habitats were deteriorating and because an increasing number of wild species was seriously threatened. Many of those threats were of a transboundary nature.

The aim of the Directive is to help maintain biodiversity through the conservation of natural habitats and of wild fauna and flora, see Article 2(1). According to Article 2(2) measures must be designed to maintain or restore natural habitats and species of wild fauna and flora of community interest. Measures have to take into account economic, social and cultural requirements as well as regional and local characteristics; see Article 2(3).

Provisions on the conservation of natural habitats and habitats of species are laid down in Article 3 to Article 11 of the Directive as well as in Annex I (natural habitat types of community interests whose conservation requires the designation of Special Areas of Conservation, SAC), Annex II (species that need Special Areas of Conservation, SAC), and Annex III (criteria for selecting sites).

These special areas of conservation (SACs), together with the special protection areas (SPAs) designated according to the Birds Directive, form a coherent network of special areas of conservation under the heading "Natura 2000", see Article 3(1) of the Habitats Directive. Natura 2000 is

60 See the Directive, with all amendments, http://eur-lex.europa.eu/LexUriServ/ LexUriServ.do?uri=CONSLEG:1992L0043:20070101:EN:PDF 
the main tool for habitat conservation. Requirements for Member States to deal with conservation measures are laid down in Article 6 of the Habitats Directive.

Rules on the protection of species are laid down in Articles 12 to 16 and in Annexes IV (species that need strict protection), V (wild species that can be restricted) and VI (prohibited methods and means of capture and killing and modes of transport) of the Habitats Directive. The Directive also aims to protect marine habitat types of Community interest, the conservation of which requires the designation of special areas of conservation, such as $(1,110)$ sandbanks, $(1,170)$ reefs and $(1,180)$ submarine structures made by leaking gases, see Annex I of the Habitats Directive. It also aims to conserve marine species of Community interest, such as harbour porpoise (Phocoena phocoena) and dolphins (Tursiops truncates), the conservation of which requires the designation of special areas of conservation, see Annex II of the Habitats Directive. There is also the Birds Directive (See Annex III) which aims to protect among others marine bird species by creating protected areas for birds such as loons (Gavia stellata, Gavia arctica, Gavia immer), see Annex I of the Birds Directive.

According to Article 17 of the Habitats Directive, information from Member States on the implementation of the measures taken under the Directive must be provided every six years in a report. Article 18 deals with research. Procedures for amending the Annexes are laid down in Article 19. Articles 20 to 21 refer to a committee established to assist the European Commission and procedures for that committee. In Article 22 there are some requirements for Member States when implementing the Directive, for example on the re-introduction of species and on providing information on the need to protect species.

Article 23 and 24 are addressed to the Member States on how and when to implement the Directive.

The Habitats Directive was originally designed for terrestrial systems and coastal waters up to 12 nautical miles (nm) from the coast (base line). However in 1999, a UK High Court ruling, commonly referred to as the "Greenpeace Judgment", extended the territory to which the Habitats Directive applies in the UK from the 12 nautical mile (nm) boundary of its territorial sea out to the limit of its $200 \mathrm{~nm}$ Exclusive Fisheries Zone (EFZ). This ruling is now generally applied. 
Member States exercise sovereign rights in their exclusive economic zone and on the continental shelf and the (Habitats and Birds) Directives are to that extent applicable beyond the territorial waters of Member States. It follows that the Directives must be implemented in that exclusive economic zone. ${ }^{61}$

\footnotetext{
61 Jouni Paavola Protected Areas Governance and Justice: Theory and the European Union's Habitats Directive. Environmental Sciences, Volume 1, Issue 1, 2004 pages 59-77. See also Case C-6/04: Commission of the European Communities versus United Kingdom of Great Britain, the Judgment of the Court (Second Chamber) of 20 October 2005. The Court declared that the United Kingdom of Great Britain and Northern Ireland had failed to fulfil its obligations under the whole of Directive 92/43/EEC of 21 May 1992 on the conservation of natural habitats and of wild fauna and flora, in particular of the whole of Directive 92/43 beyond its territorial waters, see Official Journal of the European Union C 315/5 of 10 December 2005, p. 9, http://eur-lex.europa.eu/LexUriServ/LexUriServ.do?uri= OJ:C:2005:315:0005:0006:EN:PDF
} 



\section{Annex III: \\ Protection of wild birds - EU Birds Directive}

All wild species of birds occurring naturally in the territory of the Member States of the European Union are protected, see Article 1 of the Birds Directive. ${ }^{62}$ The species of wild birds naturally occurring in the European territory of the Member States are mainly migratory species.

The Birds Directive recognises that habitat loss and degradation are the most serious threats to the conservation of wild birds. It lays emphasis on the protection of habitats for endangered birds as well as migratory species (listed in Annex I of the Directive), especially through a coherent network of Special Protection Areas (SPAs). In August 2007, the journal Science published an analysis showing that the Birds Directive has made a significant difference to the protection of many of Europe's most threatened birds from further decline. It showed that the Birds Directive has really helped those species considered to be most at risk, partly through the designation of Special Protection Areas (SPAs). ${ }^{63}$

During the last century in the Baltic Sea, several marine and coastal birds have with a few exceptions, multiplied and expanded their areas of occurrence, even if many populations have stagnated from 1980 onwards. Among those species which have become less common in their southernmost nesting areas are dunlin (Calidris alpina) and greater scaup (Aythya marila). The

\footnotetext{
62 Directive 79/409/EEC, codified version, Directive 2009/147/EC of the European Parliament and of the Council of 30 November 2009 on the conservation of wild birds, as amended. http://eurlex.europa.eu/LexUriServ/LexUriServ.do?uri=0J:L:2010:020:0007:0025:EN:PDF

63 http://www.sciencemag.org/content/317/5839/810.abstract?sid=c57db291-15a9-422d-b82f-1036f29bf169
} 
formerly very common lesser Black-backed gull (Larus fuscus) and blackheaded gull have also become scarce during the last decades. ${ }^{64}$

The Birds Directive covers the protection, management and control of naturally occurring wild birds, their eggs, nests and habitats in the territory of the European Union Member States.

General rules on the protection of species are laid down in Articles 1 to 3. According to Article 3(1) Member States must take the necessary measures to preserve, maintain or re-establish a sufficient diversity and area of habitats for all species of birds in their territory. According to Article $3(2)$, the preservation, maintenance and re-establishment of biotopes and habitats must include the creation of protected areas; see Article 3(2a).

According to Article 4, paragraph 1, (and paragraph 2 on migratory species) Member States must in particular classify the most suitable territories in number and size as special protection areas (SPAs) for the conservation of species of Annex 1 (these are species in danger of extinction, vulnerable species, rare species and species requiring particular attention), so as to ensure their survival and reproduction in their area of distribution. Member States must take similar measures for regularly occurring migratory species not listed in Annex 1, see Article 4(2). This protection includes marine birds.

According to Article 7 of the Habitats Directive, the obligation under Article 6, paragraphs 2, 3 and 4 of that Directive apply, i.e. when a site is designated as an SPA according to the Birds Directive, the SPA must be managed as any other Natura 2000 site designated according to the Habitats Directive. (See Annex VII on Natura 2000 - under the heading Management of sites).

General rules on human activities (such as killing of birds, destruction of nests and eggs and disturbance in the period of breeding) are laid down in Article 5 of the Birds Directive. Rules on the prohibition of transport and sale of birds are in Article 6(1), with general and specific exemptions in Article 6, paragraph 2 and 3 and Annex III.

64 The Baltic Sea Portal, Birds of the Baltic, Changes in nesting bird communities.

http://www.itameriportaali.fi/en/tietoa/yleiskuvaus/en_GB/780/ 
Bird species referred in Annex III, Part A, such as wild duck (Anas platyrhynchos) may be sold or transported for sale, provided that the birds have been legally killed or captured or otherwise legally acquired; see Article 6(2).

Member States may within their territory allow the sale, transport for sale, keeping for sale and the offering for sale of live or dead birds referred in Annex III, Part B, such as greylag goose (Anser anser) and the tufted duck (Aythyn fuligula) and eurasian coot (Fulica atra), provided that the birds have been legally killed or captured or otherwise legally acquired.

When granting such authorisation, Member States must first consult the Commission so they can together look at whether the marketing of specimens of such species would or could result in the population levels, geographical distribution or reproductive rate of the species being endangered throughout the Community, see Article 6(3).

These requirements ensure that hunting is sustainable. This includes ensuring that birds are not hunted during the periods of their greatest vulnerability, such as the return migration to the nesting areas, reproduction and the raising of chicks. It requires Member States to prohibit all forms of non-selective and large scale killing of birds, (especially the methods listed in Annex IV of the Directive). It promotes research to underpin the protection, management and use of all species of birds covered by the Directive (Annex V, such as endangered bird species).

According to Article 8, Member States must prohibit large-scale or non-selective capture of killing of birds (capture methods described in Annex IV). The species listed in Annex II, Part B may be hunted under certain conditions.

According to Article 9, Member States may under specific conditions (health, safety, air safety, damage to crops, livestock, fisheries, water, flora and fauna etc.) derogate from the provisions of Articles 5 to 8.

Article 10 is about research, including the subjects listed in Annex V. Article 11 is about the introduction of wild species which do not occur naturally.

Every three years Member States must send to the Commission a report on how they have implemented the national provisions applied under the Directive (Article 12(1)). Every three years, the Commission 
prepares a composite report based on the information from Member States (Article 12(2)).

Article 13 ensures that the application of measures following the Directive must not lead to the deterioration of the present conservation situation of the species. Article 14 allows Member States to introduce stricter protective measures. Article 15 is about amending Annexes I and V. Article 16 is about a Committee to help assist the Commission to adapt to technical and scientific progress and procedures for this.

The final provisions in Article 17 are addressed to the Member States on the implementation of the Directive. 


\section{Annex IV: \\ Marine Strategy \\ Framework Directive}

The Marine Strategy Framework Directive was adopted in 2008 and covers all marine areas of the EU member states. The aim of the Directive is to achieve or maintain good environmental status in the marine environment by 2020, see Article 1(1) of the Directive. ${ }^{65}$

To achieve good environmental status in the marine environment, member states must develop and implement marine strategies to protect and conserve the marine environment, prevent its deterioration or, where practicable, restore marine ecosystems in areas where they have been adversely affected (article 1(2a)) and prevent and reduce inputs in the marine environment, with a view to phasing out pollution to ensure that there are no significant impacts on or risks to marine biodiversity, marine ecosystems, human health or legitimate uses of the sea (article $1(2 \mathrm{~b})$.

According to Article 1(3) marine strategies must apply an ecosystembased approach to the management of human activities, ensuring that the collective pressure of such activities is kept within levels compatible with the achievement of good environmental status and that the capacity of marine ecosystems to respond to human-induced changes is not compromised, while enabling the sustainable use of marine goods and services by present and future generations. Furthermore, the Directive must contribute to co-

\footnotetext{
${ }^{65}$ Directive 2008/56/EC of the European Parliament and of the Council of 17 June 2008 establishing a framework for community action in the field of marine environmental policy (Marine Strategy Framework Directive). http://eur-lex.europa.eu/LexUriServ/LexUriServ.do?uri=

OJ:L:2008:164:0019:0040:EN:PDF
} 
herence between, and aim to ensure the integration of environmental concerns into, the different policies, agreements and legislative measures which have an impact on the marine environment, see Article 1(4).

As for the scope of the Directive, it applies to all marine waters as defined in Article 3(1), and must take account of the transboundary effects on the quality of the marine environment of third States in the same marine region or sub-region, see Article 2(1). The Directive does not apply to defence or national security; although they must carry out such activities in a manner that is compatible and practicable with the objectives of the Directive, see Article 2(2).

In Article 3 the Directive defines amongst others marine waters, marine regions, marine strategy, environmental status, good environmental status (supplemented by Annex I of the Directive on qualitative descriptors for determining good environmental status) and regional cooperation.

Article 4 defines marine regions or sub regions, including the Baltic Sea and the North Sea. Article 5 is about marine strategies, and Article 6 is about regional cooperation. Chapter II is about the preparation of marine strategies (see also Annex III on Indicative lists of characteristics, pressures and impacts, Annex IV on Indicative list of characteristics to be taken into account for setting environmental targets and Annex $\mathrm{V}$ on monitoring programmes), Chapter III marine strategies programmes of measures (see also Annex VI on programmes of measures), Chapter IV updating, reports and public information. Chapter $\mathrm{V}$ contains final provisions, including a regulatory Committee. 


\section{Annex V: \\ The Water Framework Directive}

The Water Framework Directive ${ }^{66}$ is established for the protection of inland surface waters, transitional waters, coastal waters and groundwater. However, the principles in the Directive are in some cases also extended to marine waters. In general, the Marine Strategy Framework Directive regulates the marine waters although this directive took over several approaches that were originally laid down in the Water Framework Directive.

The Water Framework Directive does not establish specific goals for the ecological status of the marine waters (territorial waters and marine waters, including waters beyond coastal waters). However, according to Article 2(1) the chemical status in territorial waters up to 12 nautical miles is fully covered by the Directive. Member States must also take all appropriate steps not to increase pollution of marine waters, see Article 11(6). In this respect, the Marine Strategy Framework Directive covers the environment in marine waters.

The Water Framework Directive includes amongst others the aim to protect and enhance the status of aquatic ecosystems through specific measures including the progressive reduction of discharges, emissions and losses of priority substances and the cessation or phasing-out of discharges, emissions and losses of the priority hazardous substances. The objective laid down in the Directive is that all water bodies, including coastal waters up to one nautical mile from the baseline, are of good quality status by 2015 , or latest by 2027 .

\footnotetext{
66 Directive 2000/60/EC of The European Parliament and of The Council of 23 October 2000 establishing a framework for Community action in the field of water policy, http:// eur-lex.europa.eu/LexUriServ/LexUriServ.do?uri=0J:L:2000:327:0001:0072:EN:PDF
} 
The Member States must take these measures through a programme of measures for each river basin district within its territory; see Article 11(1). According to Article 2(7) coastal water means surface water on the landward side of a line of one nautical mile on the seaward side from the baseline from which the breadth of territorial waters is measured, extending where appropriate up to the outer limit of transitional waters. 


\section{Annex VI: The EU's Common Fisheries Policy}

\subsection{The new Basic Regulation}

The Common Fisheries Policy (CFP) is set out in the so-called Basic Regulation which has been reviewed every ten years since the first one entered into force in 1983. The recently expired Basic Regulation includes such a review clause, see Article 35 of that regulation. ${ }^{67}$

The latest review was completed at the end of 2013 by the adoption of a new Basic Regulation applicable from 1st January 2014. The new Basic Regulation includes such a review clause in Article 49.

This paper is based on the new Basic Regulation Regulation. ${ }^{68}$

The Basic Regulation of 2002 was adopted by the Council, after taking into consideration the opinion of the European Parliament. The new Basic Regulation on the Common Fisheries Policy was adopted by both the European Parliament and the Council of the European Union. The changes in the power of the European Parliament are a result of the Lisbon Treaty. ${ }^{69}$

\footnotetext{
${ }^{67}$ Council Regulation (EC) No. 2371/2002 of 20 December 2002 on the conservation and sustainable exploitation of fisheries resource under the Common Fisheries Policy. http:// eur-lex.europa.eu/LexUriServ/LexUriServ.do?uri=0J:L:2002:358:0059:0080:EN:PDF

${ }^{68}$ Regulation No 1380/2013 of the European Parliament and of the Council of 11 December 2013 on the Common Fisheries Policy, amending Council Regulations (EC) No 1954/2003 and (EC) No 1224/2009 and repealing Council Regulations (EC) No 2371/2002 and (EC) No 639/2004 and Council Decision 2004/585/EC. http://eur-lex.europa.eu/LexUriServ/LexUriServ.do?uri= OJ:L:2013:354:0022:0061:EN:PDF

${ }^{69}$ Treaty of Lisbon amending the Treaty on European Union and the Treaty establishing the European Community, signed at Lisbon, 13 December 2007 - amendments to the Treaty on European Union and to the Treaty establishing the European Community Official Journal of the European Union C 306, 17.12.2007) Link to complete edition, http://eur-lex.europa.eu/JOHtml.do?uri=0J:C:2007:306:SOM:en: HTML. Consolidated versions of the Treaty on European Union and the Treaty on the Functioning of the
} 
The Basic Regulation applies to the territory of Member States to which the Treaty applies; see Article 2(b) of the regulation. The Basic Regulation defines in Article 4(2) the following geographical areas: "North Sea" means ICES zones IIIa and IV; "Baltic Sea" means ICES zones IIIb, IIIc and IIId; "North Western waters" means ICES zones V (excluding Va and only Union waters of Vb), VI and VII; "South Western waters" means ICES zones VIII, IX and X (waters around Azores), and CECAF zones 34.1.1, 34.1.2 and 34.2.0 (waters around Madeira and the Canary Islands); "Mediterranean Sea" means Maritime Waters of the Mediterranean of the East of line $5^{\circ} 36^{\prime}$ "West; "Black Sea" means the GFCM geographical sub-area as defined in resolution GFCM/33/2009/2.

The new Basic Regulation was adopted on 11 th December 2013 by the European Parliament and the Council in accordance with Article 43(2) of the Treaty on the Functioning of the European Union. ${ }^{70}$

The new Basic Regulation extends the power of Member States and the EU Commission to adopt rules on fisheries and there will be more focus on regionalisation. Basic management rules will be updated and will include further integration of environmental concerns into fisheries management.

Part I of the Regulation deals with general provisions. According to Article 1 the scope of the Common Fisheries Policy (CFP) covers the conservation of marine biological resources and the management of fisheries and fleets exploiting them on the territory of Member States to which the Treaty applies.

The objective of the CFP is to ensure that fishing and aquaculture activities are environmentally sustainable in the long-term and are managed in a way that is consistent with the objectives of achieving economic, social and employment benefits, and of contributing to the availability of food supplies, see Article 2(1). The precautionary approach will apply and aims to ensure that exploitation restores and maintains populations of harvested species above levels which can produce the maximum sustainable yield. In order to reach this objective, the maximum sustainable yield exploitation rate must

European Union: Charter of Fundamental Rights of the European Union (Official Journal of the European Union C 83, 30.03.2010.

${ }^{70} \mathrm{http}: / /$ eur-lex.europa.eu/LexUriServ/LexUriServ.do?uri=0J:C:2010:083:0047:0200:en:PDF.

The new Basic Regulation is published in the Official Journal of the European Union 28 December 2013 (L354 p. 48). 
be achieved by 2015 - where possible and on a progressive, incremental basis at the latest by 2020 for all stocks, see Article 2(2).

According to Article 2(3), the objectives include implementation of the ecosystem-based approach to fisheries management to ensure that negative impacts of fishing activities on the marine ecosystem are minimised, and endeavour to ensure that aquaculture and fisheries activities avoid the degradation of the marine environment. The CFP must contribute to the collection of scientific data, see Article 2(4).

The CFP must also be coherent with the Union environmental legislation, in particular the objective of achieving good environmental status by 2020, which is set out in Article 1(l) of Marine Strategy Framework Directive $2008 / 56 / \mathrm{EC}^{71}$ as well as with other Union policies, see Article 2(5j) of the Basic Regulation.

Article 3 concerns principles of good governance, such as a clear definition of responsibilities at Union, regional, national and local levels, regional specificities through a regionalised approach, establishment of measures in accordance with the best available scientific advice, a longterm perspective, administrative cost efficiency and appropriate involvement of stakeholders, in particular of Advisory Councils, at all stages from conception to implementation of the measures.

Article 4 includes mostly the same definitions as in the previous Basic Regulation, but some of them are updated and deepened, especially those related to environmental concerns, such as low impact fisheries. This Article of definitions is heavily supplemented by fisheries related terms, including the fisheries zones to which the rules apply.

Part II of the new Basic Regulation concerns access to waters (see also Annex I Access to Coastal Waters). Part III deals with measures for the conservation and sustainable exploitation of marine biological resources (Title I conservation measures, Title II specific measures, Title III regionalisation, Title IV national measures), Part IV deals with management of fishing capacity (see also Annex II Fishing Capacity Ceilings), Part V with the scientific base for fisheries management, Part VI with external policy

${ }^{71}$ http://eur-lex.europa.eu/LexUriServ/LexUriServ.do?uri=0J:L:2008:164:0019:0040:EN:PDF 
(Title I international fisheries organisations, Title II sustainable fisheries partnership agreements, Title III management of stocks of common interest), Part VII aquaculture, Part VIII common market organisation, Part IX control and enforcement, Part X financial instruments, Part XI on the Advisory Councils (see also Annex III on the Advisory Councils), Part XII procedural provisions and Part XIII final provisions. 


\section{Annex VII: \\ The Natura 2000 process - A network of protected areas}

Natura 2000 is the centrepiece of the EU's nature and biodiversity policy. It is an EU wide network of nature protection areas established under the 1992 Habitats Directive. The aim of the network is to assure the long-term survival of Europe's most valuable and threatened species and habitats. It consists of Special Areas of Conservation (SAC) designated by Member States under the Habitats Directive and incorporates Special Protection Areas (SPAs) which they designate under the 1979 Birds Directive. The establishment of this network of protected areas also fulfils a Community obligation under the UN Convention on Biological Diversity.

\subsection{The EU Biodiversity Strategy}

In March 2010, EU leaders recognised that the 2010 biodiversity target would not be met, despite some major successes, such as establishing Natura 2000, the world's largest network of protected areas. So they endorsed the long-term vision and ambitious headline target proposed by the Commission in its Communication "Options for an EU vision and target for biodiversity beyond 2010." This new strategy postponed the 2010 target for halting biodiversity loss to 2020 and the target for restoring biodiversity is now 2050. Member States have to take the necessary measures to achieve or maintain good environmental status in the marine environment by 2020 at the latest (Article 1 of the Marine Strategy Framework Directive).

The procedures are unaffected by the 2010 Biodiversity Strategy. The aim of the Habitats Directive is to contribute towards ensuring biodiversity through the conservation of natural habitats and of wild fauna 
and flora in the European territory of the Member States to which the Treaty applies, Article 2(1) of the Directive.

Measures taken according to this Directive must maintain or restore, at favourable conservation status, natural habitats and species of wild fauna and flora of Community interest, see Article 2(2).

A coherent European ecological network of special areas of conservation must be created under the title Natura 2000. The aim of this network, composed of sites hosting the natural habitat types listed in Annex I and habitats of the species listed in Annex II of the Directive, is to enable the natural habitat types and the species habitats concerned to be maintained or, where appropriate, restored at a favourable conservation status in their natural range, see Article 3(1).

The Natura 2000 network must include the special protection areas classified by the Member States according to the Birds Directive 79/409/EEC.

\section{The legal basis}

The Natura 2000 programme is based on the Habitats and Birds Directives.

According to Article 3(1) of the Habitats Directive, a coherent European ecological network of special areas of conservation (SAC) must be set up under the title Natura 2000. This network is composed of sites that host natural habitat types of community interests listed in Annex 1. The Natura 2000 network of sites must also include habitats of species listed in Annex II (species that need special areas of conservation). The Natura 2000 network of sites must also include habitats of species listed in Annex II (animal and plant species of community interest whose conservation requires the designation of Special Areas of Conservation) in order to ensure that these features can be maintained or, where appropriate, restored at a favourable conservation status in their natural range.

The Natura 2000 network also includes the special protection areas (SPA) classified by the Member States following the Birds Directive. The species listed in Annex I are in danger of extinction, or are vulnerable to specific changes in their habitat. They are rare (small population or restricted local distribution) or need particular attention (specific nature of their habitat) and need special conservation measures in their habitat to ensure their survival and reproduction in their area of distribution. The Member States must classify the most suitable territories in number and 
size as special protection areas for conservation (SPA) in the geographical sea and land areas; see Article 4(1) of the Birds Directive.

Member States must also take similar measures for regularly occurring migratory species not listed in Annex I. Migratory species are species that need protection in the geographical sea and land area, with respect to breeding, moulting and wintering areas and staging posts along their migration routes, see Article 4(2) of the Birds Directive.

Migratory species, including sea birds, may pose extreme challenges for the Member States as well as transboundary habitats. Cross border cooperation is needed in many cases, not only between EU-Member States. In the Baltic Sea cooperation with Russia may be needed. In the North Atlantic Ocean cooperation with Norway, Faroe Islands, Iceland and even Greenland may be needed.

\subsection{Natura 2000 - Designation of sites}

The Natura 2000 network covers priority natural habitat types or priority species in the territory of the Member States (Article 2(2)) and outstanding examples of typical characteristics of nine biogeographical regions referred to in Article 1(c, iii) which include the North Sea and the Baltic Sea.

\section{Conservation of marine habitats}

\begin{tabular}{ll} 
No. 1110 & Sandbanks which are slightly covered by sea water all the time \\
No. 1120 & Posidonia beds (Posidonion oceanicae) \\
No. 1130 & Estuaries \\
No. 1140 & Mudflats and sandflats not covered by seawater at low tide \\
No. 1160 & Large shallow inlets and bays \\
No. 1170 & Reefs \\
No. 1180 & Submarine structures made by leaking gasses \\
No. 1650 & Boreal Baltic narrow inlets \\
No. 8330 & Submerged or partially submerged sea caves. \\
\hline
\end{tabular}

The Habitats Directive states 9 priority marine habitat types in Annex I.

\section{Conservation of marine species}

There are many marine species listed in Annex II of the Habitats Directive. These include cetaceans, seals, reptiles, invertebrates and plants. Anadromous fish species are also listed. Conservation of the species listed in 
Annex II of the Habitats Directive requires the designation of special areas of conservation.

Many seabirds, waders and wildfowl are listed in Annex I of the Birds Directive.

Endangered or migratory marine bird species are conserved through the establishment of Special Protection Areas (most suitable territories). These SPAs form, together with all other SACs, an integral part of the Natura 2000 network.

\section{Creation of Natura 2000}

According to Article 3(2), of the Habitats Directive, each Member State must contribute to the creation of Natura 2000 in proportion to the representation within its territory of the natural habitat types and the habitats of species referred to in paragraph 1 , by proposing a list of sites to the Commission, giving information on each site, including a map of the site, its name, location, extent and data (Article 4(1)).

\section{EU Commission Guidelines}

The European Commission's position on marine Natura 2000 is reflected in its Guidelines for the establishment of the Natura 2000 network in the marine environment - Application of the Habitats and Birds Directives (May 2007). ${ }^{72}$ To many Member States these guidelines provide the most important basic information and contribution to the designation process of Natura 2000. The guidelines provide comprehensive reference to other documents that provide further information such as on legal aspects and assessment of the importance of sites.

\section{Marine Expert Group}

Since March 2003, a Marine Expert Group has been working to develop a common understanding of the provisions of Natura 2000 relating to the marine environment in order to facilitate the designation and future management of these areas. This group is an important forum for exchange of experience and the update of the development of the Natura 2000 net-

\footnotetext{
72 http://ec.europa.eu/environment/nature/natura2000/marine/docs/marine_guidelines.pdf
} 
work. Hosted by the EU Commission (DG Environment), Member States as well as stakeholder representatives take part at this.

\section{The national approach}

The obligation to designate Natura 2000 sites lies with each Member State of the Union. The designation process begins at national level and involves national competences. The national procedures may differ from one country to another. The information basis may also be different. The assessment of the criteria for designation of Natura 2000 sites may differ between countries.

EU Member States have not designated their marine Natura 2000 sites at the same time and this may cause problems in trans-boundary coordination of sites which are adjacent to each other on both sides of the borderline. Each Member State also has to meet the timetable of the national designation process. When the starting point is at national level, cooperation may end up with a coordination of the results from each single country and this may prolong the designation process.

The EU Commission encourages Member States to coordinate their work. It also organises so-called bio-geographical seminars where Member States have the opportunity to discuss their list of designated areas, their assessment of it and their approach to the Natura 2000 designation. Again, when the starting point is at national level, cooperation may end up with a coordination of the results from each single country, and this may prolong the designation process, management plans and/or fisheries measures to be taken in Natura 2000 sites of the EEZ.

There are examples where the habitat stretches into third country waters or where a third country has fishing or conservation interests in a proposed N2000 site. Examples include Skagerrak (Norway) (Bratten) and the Baltic (Russia). The approach differs. Whereas the Bratten case is dealt with at municipality level, the Baltic case is dealt with through the international inter-governmental HELCOM mechanism, illustrating a flexible response to the problem by taking into account the governance structure of the third country. 


\section{Designation Status}

By the end of 2,012, 27 EU Member States had designated a total of 28,553 sites (land and marine) on an area of $1,009,678.40 \mathrm{~km}^{2}$. The 3 Nordic EU Member States designated 7,002 sites $\left(180,803.98 \mathrm{~km}^{2}\right)$ of which 742 $\left(35,446.86 \mathrm{~km}^{2}\right)$ are marine sites. Denmark designated 130 marine sites $\left(19,011.67 \mathrm{~km}^{2}\right)$, Finland 168 marine sites $\left(7,224.64 \mathrm{~km}^{2}\right)$ and Sweden 444 marine sites $\left(9,210.55 \mathrm{~km}^{2}\right)$. DG Environment provides an update on designation status. ${ }^{73}$

\subsection{Preparing the selection of Natura 2000 sites}

According to Article 4(1) of the Habitats Directive, Member States select their sites on the basis of the criteria in Annex III and on scientific information. The selection is carried out in two stages. Stage 1 is about assessing the importance of sites for natural habitat type in Annex I and for each species in Annex II of the Directive. Stage 2 is about assessing the Community importance of the sites included on the national list.

\section{Stage 1. Assessing the importance of sites}

Stage 1 is the assessment of the importance of sites for natural habitat types in Annex I and each species in Annex II of the Directive. In other words, Member States have to explain why they designate a site.

When drawing up the list, each Member State makes use of the information available, i.e. from experts according to their own procedures and traditions. Some countries have their own legislation and/or guidelines. Some Member States will use their own management system and some will use other national expert institutions. Others may draw upon international institutions or bodies.

The national list of sites will contain the proposed sites of Community importance and show the priority natural habitat types and priority species.

${ }^{73} \mathrm{http} / / /$ ec.europa.eu/environment/nature/info/pubs/docs/nat2000newsl/nat34_en.pdf 


\section{1 a) Information needed}

The European Commission has elaborated a standard format on the information that is needed. ${ }^{74}$

This includes information on each site, i.e. a map of the site, including its boundaries, name, location and extent. The information must also include the data which comes from applying the selection criteria specified in Annex III of the Habitats Directive, i.e. Annex II species and Annex I habitats types significantly present in each site compared to the rest of the national territory.

\section{1 b) Information from other sources}

The knowledge of the structure and functions of marine habitats is generally sparse and incomplete and the dynamics of marine habitats are not sufficiently understood so as to be able to model how a habitat would look if relieved of the pressure from human activities. The classical assessment approach is done by comparing occurrence and abundance of species typical for the habitat between historic data and the results from a current survey. So there is an active search for old data from a variety of sources, such as old fishing charts or old biological studies. In general, reducing the pressure from human activities is expected to favour long-lived species at the cost of more opportunistic species. So an indirect method to estimate the conservation of structure and functions is to assess the naturalness of the habitat using information on location and intensity of damaging activities and by comparison with historical data for certain habitats.

The obligation in Article 11 to undertake surveillance of the conservation status of the natural habitats and species, particular priority habitats and species, may provide useful information.

The obligation in Article 12(1) of the Habitats Directive to take measures to establish strict protection for animal species in their natural range, listed in Annex IV(a) i.e. vertebrates such as mammals and the obligation to monitor incidental capture and killing of them, may provide useful information of species and habitats. In the light of the information

\footnotetext{
${ }^{74}$ Commission Implementing Decision of 11 July 2011 concerning a site information format for Natura 2000 sites (http://eur-lex.europa.eu/LexUriServ/LexUriServ.do?uri=CELEX:32011D0484:EN:NOT)
} 
gathered they must carry out further research or take appropriate conservation measures so as to prevent significant negative impact on the species (Article 12(4)).

\section{1 c) Representativeness of the sites}

Member States must produce a description of the representativeness of sites with respect to similar habitats in the rest of the national territory. The description will include the structure and functions of the natural habitat (Annex I habitats types) of the sites and whether they can be restored. It will also include a global assessment of the value of the site for conservation of the natural habitat type concerned.

As for the designation of sites to protect Annex II species, Member States produce a description of the size and density of the population of the species present on site in relation to the presence of their population within the national territory. It must also include information on how important the site is for the conservation of the present populations and restoration possibilities. The description will include the importance of the site to the population (the isolation) compared to their natural range of the species. It will also include a global assessment of the value of the site for conservation of the species.

\section{1 d) Classifying sites}

By using the criteria in Annex III, Member States will to a great extent be able to prioritize habitat types and species, and classify and identify the sites in order to propose sites of Community importance.

\section{1 e) Cross border cooperation}

Already at stage 1 level, global assessment of habitats and species may call for cooperation with neighbouring countries; Cooperation at this stage may pave the way for sharing data on trans-boundary habitats and species, including migratory species and the assessment. Depending on the need for cooperation, this could be the key incentive for further cooperation on the designation (area boundaries and species) of sites.

It is very often the case that a site designated to protect habitats is important for several species, including species that need special protection. 


\section{$1 \mathrm{f})$ Transmission of list of sites to the Commission}

Member States send their list, together with data and scientific information to the European Commission; see Article 4(1).

The so-called Habitats Committee helps the European Commission to implement the Habitats and Birds Directives. Additional guidelines for assessing marine sufficiency were also developed through the Habitats Committee ahead of the marine bio-geographical seminars.

Based on discussions in the Habitats Committee, the Commission has indicated that a list of sites of Community importance should normally cover at least $20 \%$ of the resource to be protected. More than $60 \%$ would normally be considered sufficient. However, the sufficiency of representation within the Natura 2000 network has to be assessed on a case by case basis.

\section{Stage 2. Assessment of the Community importance of sites (SCI)}

Stage 2 is the assessment of the Community importance of the sites included on the national list. Sites of Community Importance (SCI) are the basis for the European Natura 2000 network. Most designated sites are of Community importance, so will be a part of the Natura 2000 network.

According to Article 4(2), the European Commission establishes, in agreement with each Member State, a draft list of sites of Community importance based on the criteria in Annex III. The assessment includes among other things the geographical situation of the sites in relation to migration routes of species and whether they belong to a continuous ecosystem on both sides of or more international Community frontiers and the global ecological value of the site for the bio-geographical regions concerned.

Member States will organise a public hearing on the proposed list. 


\section{2 a) Scientific consultation}

When the European Commission has received the national list of sites, it consults European Topic Centre on Biological Diversity. ${ }^{75}$ The Centre assesses the list on a case by case basis, i.e. species by species and habitat by habitat, taking into account all available information.

\section{2 b) Bio-geographical seminars}

The European Commission organises bio-geographical seminars to discuss the results of the assessment, together with a list of sites in other countries in the region with all Member States of the region concerned. Experts from stakeholders in the region, users and environmental NGOs may attend the seminars. The European Environment Agency ${ }^{76}$ supports the seminars through the European Topic Centre on Biological Diversity. The first marine Atlantic Seminar was held in 2009 and the first marine Baltic Seminar was held the same year. The marine seminar for the Mediterranean, Black-Sea and Macaronesia was held in 2010.

\section{2 c) Identification of SCI}

The European Commission and the Member State then will identify those sites which host one or more priority natural habitat types or priority species (SCI).

\section{2 d) The Commission adoption of SCI}

According to Article 4(2), the Commission will adopt the list in accordance with the procedure laid down in Article 21.

\section{2 e) Presentation by the Commission of SCI to the Regulatory Committee}

The procedure in Article 21of the Habitats Directive includes the presentation of the list of SCI to the Regulatory Committee referred to in that Article. This Committee is composed of representatives of Member States and is chaired by a representative from the Commission. (The votes of the

$75 \mathrm{http}: / /$ bd.eionet.europa.eu/

$76 \mathrm{http}: / /$ www.eea.europa.eu/ 
representatives of the Member States within the Committee are according to the Treaty rules). The chairman does not vote; see Article 5 of Decision 1999/468/EC. ${ }^{77}$ This decision has been repealed and replaced by Regulation (EU) No 182/2011,78 see Article 12 to 14 of regulation 182/2011. The Regulatory Committee referred to in Article 21 operates according to the new procedure.

\section{Adoption of Natura 2000 sites}

\section{3 a) Adoption by the Commission of SCI}

When the Committee has supported the Commission's list of SCI, it is finally adopted by the Commission.

The Commission's adoption of the list of sites triggers the obligations in Article 6(2), (3) and (4); see Article 4(5), on managing the Natura 2000 sites.

\section{3 b) Designation by Member States of SAC}

The legal effects of the Commission's adoption of the list of Sites of Community importance (SCI) is the obligation by Member States to designate the sites as a special areas of conservation (SAC) as soon as possible and within six years after the Commission has adopted the list of SCI, see Article 4(4) of the Habitats Directive. The designation of SACs requires a legally binding act. The areas must be put into priority according to how important the sites are for the maintenance or restoration at favourable conservation status of a natural habitat type in Annex I or species in Annex II and for the coherence of Natura 2000, and in the light of the threats of degradation or destruction to which those sites are exposed.

The adoption of national legislation will follow the national legislative procedures, including consultation of stakeholders.

\footnotetext{
77 http://eur-lex.europa.eu/LexUriServ/LexUriServ.do?uri=CONSLEG:1999D0468:20060723:EN:PDF ${ }^{78}$ Regulation (EU) No 182/2011 of the European Parliament and of the Council of 16 February 2011 laying down the rules and general principle concerning mechanisms for control by Member States of the Commission's exercise of implementing powers. http://eur-lex.europa.eu/LexUriServ/ LexUriServ.do?uri=0J:L:2011:055:0013:0018:EN:PDF
} 


\subsection{Natura 2000 - Management of sites}

According to Article 6(1) of the Habitats Directive, Member States must take appropriate conservation measures to maintain and restore habitats and species for which the site has been designated to a favourable conservation status. In other words, to establish conservation measures or management plans for each of the sites so as to maintain or restore favourable conservation status for the Annex I habitats and Annex II species that have been the reason for designating the site.

In order for Member State authorities to be able to interpret Article 6, the European Commission has provided a guidance document: Managing Natura 2000 sites - The provisions of Article 6 of the Habitats Directive 92/43/EEC. 79

Conservation measures or management plans according to Article 6 are most important to the conservation of marine habitats and species. The implementation of Article 6 will actually ensure the conservation that is intended and planned and the management of the Natura 2000 sites. For more on Article 6 on managing and conserving Natura 2000 sites. $^{80}$

\section{Integration of measures/management plans}

These measures can be integrated into other plans, as well as appropriate statutory, administrative or contractual measures. The option to integrate measures into other legal acts is of great importance in fisheries. Implementing fisheries measures for each single SAC in marine areas will cause considerable administrative burden. But there may be reasons that justify specific fisheries measures for some specific sites. One example would be two Commission regulations, (EC) 1475/2003 and 263/2004 on the protection of deep- water coral reefs from the effects of trawling in the Darwin Mounds, North West of Scotland. The option of integrating Natura 2000 concerns into fisheries policy makes it possible to look at fisheries

\footnotetext{
${ }^{79} \mathrm{http}: / /$ ec.europa.eu/environment/nature/legislation/habitatsdirective/index_en.htm\#sdf

${ }^{80} \mathrm{http}: / /$ ec.europa.eu/environment/nature/natura2000/management/guidance_en.htm\#art6
} 
with a focus on Natura 2000 issues in a broader fisheries context. Some migratory species may give good reasons for conservation in a broader context. One example would be the regulation of fisheries to reduce bycatch of cetaceans, see Council Regulation 812/2004.

According to Article 7 of the Habitats Directive, the obligation under Article 6(2), (3) and (4) of the Habitats Directive applies, i.e. when a site is designated as an SPA according to the Birds Directive, the SPA must be managed in the same way as other Natura 2000 sites designated according to the Habitats Directive.

\section{Measures/management plans}

Conservation measures or management plans are in place when the designation by Member States of SACs enters into force, i.e. as soon as possible and within six years after the Commission's adoption of the list of Sites of Community importance (SCI).

The choice of measures and/or management plan will depend on the legal system and tradition of each Member State. However, a management plan will be preferable because it makes space for more and comprehensive information and considerations rather than a strict legal measure on the global and specific objective, the identification of what is conserved and/or restored, the target protection level etc. In a fisheries context a management plan will be preferable because the plan will explain each single step of the plan and more information on who is going to do what and when, so that makes the division of competences between authorities more transparent.

\section{The content of a management plan}

A management plan suggests a plan which will include the location of the site (a map with precise boundaries). It will refer to the purpose of the designation, which is to contribute to enabling the natural habitat types and species of the site to be maintained or, where appropriate, be restored to a favourable conservation status. The habitats and/or species of the site and those habitats and or species that need protection according to the Habitats and Birds Directives will be identified. The ecological status 
(population size and density/habitat status is excellent, good or significant, representative) and importance of the site will be included as well as the status and importance of the habitats and/or species in regional, national and/or international context, including the Natura 2000 network.

The plan will also identify those human activities that pose threats and degradation to species and/or habitats of the site and the degree of removal of these threats and a time frame so as to maintain or restore favourable conservation status for the Annex I habitats, Annex II species and the bird species.

Human activities which could pose threats could be transport, fisheries, aquaculture, pollution, military activities, exploitation of oil and minerals in the subsoil, wind and wave energy, tourism etc.

It is unlikely that one single authority in each country can regulate all human activities at sea in a way that matches the organisation of its environmental authorities. Each authority is organised to match the activity it regulates in accordance with the traditions in the country. Very often these authorities are centralized and supplemented by local authorities to match local needs. The environmental authorities will be centralized and some type of tasks will be delegated to regional and/or local authorities.

\section{Responsible authorities manage human activities}

The authorities responsible for human activities must take measures to reduce or eliminate threats according to the management plans. Protection of habitats and species beyond 12 nautical miles will be mostly regulated by centralized units. For example, human activities beyond 12 nautical miles are regulated by the centralized units as in Germany, whereas this is not the case in Sweden.

If fisheries has been identified as a threat to the favourable conservation status of a site outside 12 nautical miles, the competence to take nondiscrimination measures lies within the Common Fisheries Policy of the $\mathrm{EU}$, see later on the decision procedure in fisheries management. 


\section{Cross border coordination}

The European Commission encourages Member States to ensure a good coordination between fishery and environmental authorities at Member State level and with stakeholders, which they do.

\section{Legal consequences}

\section{To stop deterioration and disturbance}

When the Commission has adopted the list of sites of Community Importance (SCI), Member States must according to Article 6(2) of the Habitats Directive avoid damaging activities that could significantly disturb these species or cause deterioration of the habitats of the protected species or habitat types. Member States have to take appropriate steps to avoid such deterioration and disturbance of Natura 2000 sites if they fall under the objectives of the Directive. ${ }^{81}$

This provision does not make sense if human activities can continue until six years after the Commission's adoption of the SCI until the conservation measures and/or the management plans are in place and thus continue to have a significant deterioration and disturbance effect on the site.

The competence to take fisheries measures lies within the Common Fisheries Policy of the EU, and this is explained later.

\section{Future human activities in Natura 2000 sites}

Plans and projects not directly linked to the management of the site, but which are likely to have a significant effect on the management of the site, either individually or in combination with other plans or projects must be assessed for the implications they may have for the site in view of the conservation objectives of the site, see Article 6(3). The competent authorities can only agree to such plans and projects if the assessment concludes that they will not adversely affect the integrity of the site con-

81 http://ec.europa.eu/environment/nature/legislation/habitatsdirective/index_en.htm\#sdf 
cerned and, if appropriate, after having obtained the opinion of the general public.

If fisheries have a significant effect on the management of a site, fisheries (authorities) must provide such an assessment. An appropriate assessment is the so-called Environmental Impact Assessment according to Council Directive 85/337EEC of 27 June $1985 .{ }^{82}$

\section{Overriding public interest}

If the assessment of such plans or projects is negative, then they may be carried out for reasons of overriding public interest, including those of a social or economic nature. They can be implemented, providing there is no alternative solution. The Member State takes all necessary compensatory measures to ensure that the overall coherence of Natura 2000 is protected, see Article 6(4). The Member State must inform the Commission of the compensatory measures adopted.

If fisheries are affected by such compensatory measures, then fisheries interests will be involved.

Compensatory measures cannot apply to sites that host a priority natural habitat type and/or a priority species, unless they include considerations related to human health or public safety, to beneficial consequences of primary importance for the environment or, further to an opinion from the Commission, to other imperative reasons of overriding public interest (Article 6(4)).

\section{Revision of conservation measures/management plan}

The dynamics of ecosystems, together with human impacts and climate change, new technology and other new information, may result in changes of a site (habitats and species). Some sites may have become more important and others less important. New sites might need to be designated,

\footnotetext{
82 Council Directive 85/337EEC of 27 June 1985 on the assessment of the effects of certain public and private projects on the environment. Official Journal No. L 175, 05/07/1985 p. 40-48) (http:// eur-lex.europa.eu/LexUriServ/LexUriServ.do?uri=0J:L:1985:175:FULL:EN:PDF
} 
others expanded and others reduced or even removed from the Natura 2000 network.

The assessment of conservation status and declining biodiversity will be important indicators for a revision of conservation measures and management plans.

The revision clause of the management plan will show when it is time for review.

\subsection{Fisheries and fisheries measures in Natura 2000 sites}

The EU has exclusive competence to regulate fisheries. The European Commission has the right of initiative in proposing fisheries regulations. The European Parliament and the Council together adopt EU fisheries regulations. The European Parliament and the Council have in accordance with Article 46 of the Common Fisheries Basic Regulation ${ }^{83}$ empowered the Commission to adopt Union fisheries measures in Natura 2000 sites upon a request from Member States, by means of delegated acts.

Member States are authorized to adopt conservation measures in Natura 2000 sites in their own waters if these measures solely affect their own vessels, see Article 11(1) of the Basic Regulation.

If fisheries measures affect own vessels only, Member States will check whether a Natura 2000 site is bordering a Natura 2000 site of a neighbouring country. If so, the Member State should consider cooperating with the neighbouring state according to Article 6(3) of the Basic Regulation. There are good reasons to cooperate if habitats, species and/or features in the sites of both Member States are similar and the fishery in both sites is similar. Such cooperation will provide synergies on scientific data and advice and on the consultation of stakeholders.

The aim of the cooperation is to ensure that both Member States adopt the same measures in cross-bordering sites in accordance with Article 11

\footnotetext{
${ }^{83}$ http://eur-lex.europa.eu/LexUriServ/LexUriServ.do?uri=OJ:L:2013:354:0022:0061:EN:PDF
} 
(on conservation measures necessary for the purpose of compliance with obligations under Union environmental legislation) and Title III (on regionalisation).

Fishing vessels have equal access to waters and resources in all Community waters; see Article 5(1) of the Basic Regulation and fishing vessels from every EU Member State can operate in the EEZ of a Member State, provided that they have a quota to fish. However, Member States have reserved access to waters inside 12 nautical miles for their own fishermen, but they must respect existing arrangements that allow access to foreign fishing vessels inside 12 nautical miles, see Article 5(2) of the Basic Regulation and Annex I.

When a Member State has established that a fishery in a Natura 2000 site is a threat to achieving conservation objectives and measures must be taken according to Article 11, and fishermen from other Member States (Member States concerned) will be affected, measures will be taken by the Union, i.e. the Commission will be empowered, by means of delegated acts and upon a request by Member State together with Member States concerned to adopt such measures, see Article 11(2) of the Basic Regulation. The Member State and Member States concerned must cooperate in preparing such a request, see Article 11(3) of the Basic Regulation. For this purpose, Article 18(1)-(4) and (6) on regionalisation (regional cooperation on conservation measures) shall apply mutatis mutandis.

Fisheries measures for all Natura 2000 sites in the EEZ and for those Natura 2000 inside 12 nautical miles where other Member States have fishing management interests follow the same procedure.

The European Commission provides a comprehensive Common methodology for assessing the impact of fisheries on marine Natura $2000 .^{84}$

\footnotetext{
${ }^{84}$ Dated 6 November 2012 http://ec.europa.eu/environment/nature/natura2000/marine/docs/ Fisheries\%20methodology.pdf
} 


\section{National Preparatory work}

During the designation process, the environmental authority responsible has identified the threats to the Natura 2000 site and has assessed the impact of human activities on Natura 2000 site. Where fisheries are identified as a threat fisheries measures should be in place as soon as possible and within six years after the Commission's adoption of the list of Sites of Community Importance (SCI). The national environmental authority responsible informs and discusses the designation and the management plan with those authorities responsible for activities that threaten good environmental condition of the habitat, species and/or feature of the Natura 2000 sites in their waters.

The national fisheries authority responsible has the opportunity to consider and plan if, how and when to take fisheries measures to minimize or eradicate the threat and to determine which authority has the competence to take fisheries measures to do that.

Fisheries measures to protect Natura 2000 will be decided by the authority responsible, depending on the location of sites and fisheries interests involved. The decision process will be initiated at national level by the fisheries authorities of a Member State, regardless of the interests involved.

The national fisheries authorities must examine the environmental authority's act of designating Natura 2000 sites and this will show when the designation enters into force.

The national authorities also have to check if urgent action is needed.

If the threat from fisheries is significant to the objective of the Habitats Directive, appropriate steps have to be taken to avoid deterioration and disturbance of Natura 2000 sites when the sites are designated (Habitats Directive Article 6(2)).

Fisheries plans and projects which are likely to have a significant effect on the management of a site or in combination with other plans, must be subject to an appropriate assessment of their implication for the site in view of the site's conservation objective when the site is designated (Habi- 
tats Directive Article 6(3)). Fisheries (authorities) must provide such assessment. An appropriate assessment is the so-called Environmental Impact Assessment. ${ }^{85}$

The Member State where the Natura 2000 site is located must provide the Commission and the other Member States concerned with relevant information on the measures required, including rationale, scientific evidence and details on practical implementation and enforcement, see Article 11(3) of the Basic Regulation. The EU Commission has provided an approach to the information that is needed to elaborate a proposal for fisheries regulation in a Natura 2000 site. ${ }^{86}$ Monitoring by the environmental authorities of sites and fisheries control of fisheries in the areas of sites will most likely provide improved data on the sites and the surrounding areas.

\section{Consultation of stakeholders}

When preparing fisheries measures in a Natura 2000 site and these measures affect other Member States fishery, Member States should consult Advisory Councils of the region keeping in mind that Article 18(1) to (4) and (6) applies mutatis mutandis when Article 11 applies (regional cooperation on conservation measures).

The Commission has recommended that at an early stage Member States must involve the Advisory Councils of the region where the Natura 2000 site is placed. The Advisory Councils represent interests in fisheries and environment of their region. Fishermen can through the Advisory Councils of the region provide important data on fisheries activities, modification of gears and other data on the site.

The involvement of stakeholders at national level takes place according to the rules and practices of the Member States.

\footnotetext{
${ }^{85}$ Council Directive 85/337EEC of 27 June 1985 on the assessment of the effects of certain public and private projects on the environment. Official Journal No. L 175, 05/07/1985 p. 40-48, http:// eur-lex.europa.eu/LexUriServ/LexUriServ.do?uri=OJ:L:1985:175:FULL:EN:PDF

86 http://ec.europa.eu/environment/nature/natura2000/marine/docs/fish_measures.pdf.
} 


\section{Regional cooperation}

When the Member State has prepared a paper on available information on a Natura 2000 site in a certain geographical area, it will be the basis for regionalised discussions with Member States concerned, because their fishermen will be affected by fisheries measures taken in the Natura 2000 site. When sufficient information is available, the Member States may provide scientific advice which will be discussed in the framework of the regionalised cooperation.

The Member States must cooperate in preparing a request to the Commission to take Union fisheries measures in the Natura 2000 sites, see Article 11(3). For this purpose, Article 18(1), must apply mutatis mutandis (regional cooperation on conservation measures).

The request may include specific management measures based on the information provided. In this respect, According to Article 1 of the Basic Regulation, the scope of the Common Fisheries Policy (CFP) covers the conservation of marine biological resources and the management of fisheries and fleets exploiting such resources on the territory of Member States to which the Treaty applies.

Enforcement follows the general rules of each Member State. Natura 2000 sites may give reasons for specific measures. A buffer zone may prevent vessels from entering the area unnoticed. Modern equipment such as Vessel Monitoring Systems (VMS) on board each vessel could be upgraded so as to control vessel movement close to and in the site. These questions should be mentioned in the request to the Commission.

The joint request must be submitted to the Commission within six months from the provision of sufficient information, see Article 11(3).

\section{Cooperation under the Basic Regulation}

The Commission strongly recommends that Member States submit their requests in the same regional sea at the same time. This will make the work for the Member States and the Commission easier. Member States will also benefit from a cross-border coordination with neighbouring states when they have a joint request for scientific advice as well as a coordinated request for management measures to the Commission on sites in a region rather than on a case-by case basis because the Natura 2000 
sites will be more consistent and dealt with in a coherent (Natura 2000 network) way.

Under the Basic Regulation 2002-2013, the Commission's approach was to encourage Member States to coordinate their work with neighbouring Member States as appropriate. Such cooperation is appropriate when two or more countries have designated sites up to the borderline of the neighbouring country to conserve cross-border features, habitats or species in their territory. This coordination may be different from Member State to Member State.

Such coordination is organised in the case of the Dogger Bank sandbank in the North Sea (Germany, Holland and the UK designation) and Bassurelle sandbank in the Channel (France and UK) and in the Kattegat Bratten (Sweden).

Experience from the Dogger Bank process shows that the designation process started in Germany then in the Netherlands, and finally in the UK. When the designation in such areas is not coordinated from the beginning, it causes problems for all involved. In the case of Dogger Bank the boundaries of the areas were coordinated at a later stage in the process. However, some coordination must have been taken at the bio-geographical seminar. The assessment of the habitat and species that need protection in the sites was initially handled at national level. A comprehensive coordination took place at a later stage. So discrepancies were solved at a later stage. The country that provides the first delivery of site designation has to stick to the agreed results in their countries for political reasons. The country that is the last one to start the designation process has to be offensive in its approach if its assessment does not match that of the first country. Such problems may prolong the coordination process.

The differences in approaches are seen as a major obstacle to the efficient implementation of an "ecosystem approach" to fisheries management and to a holistic approach to management of human impact on the marine ecosystem. 


\subsection{The Commission adoption of measures}

\section{Commission preparation}

When the Commission has received a request, it will examine it in the light of the objectives of the Natura 2000 site and the proposed measures consistency with Union policies, regional specificities, the scientific advice, the use of impact assessments, cost efficiency and the involvement of stakeholders.

According to Article 11(2), the Commission is empowered, by means of delegated acts to adopt fisheries measures in the Natura 2000 sites. These acts must be adopted according to Article 46 of the Basic Regulation. For this purpose, Article 18(1)-(4) and (6) must apply mutatis mutandis (regional cooperation on conservation measures).

The Commission will not adopt a delegated act before the expiry of the deadline for submission of a joint request by the Member States (Article 11(3)). The Commission will nevertheless adopt the measures within 3 months of the receipt of a complete request. The Commission will take into account any available scientific advice; see Article 11(3). If the request is incomplete, the Commission needs more time.

\section{Absence of a joint request}

If the regionalised cooperation between Member States does not result in a request to the Commission within the deadline (six months from the provision of sufficient information), or if the joint request on conservation measures are deemed not to be compatible with the objectives and quantifiable targets of the conservation measures in question, the Commission may submit a proposal for appropriate measures in accordance with the Treaty, see Article 18(6).

If Member States cannot agree on a request to the Commission, the Commission may propose measures under the relevant Treaty procedure; see Article 11(3).

In order to prevent further destruction of Natura 2000 sites, the Commission may take emergency measures. These measures must establish a conservation of the Natura 2000 site which avoids putting the objectives of the Natura 2000 site in jeopardy, see Article 11(4). 
Emergency measures will be limited to 1 year. The Commission may extend the application of such measures for a further 12 months, provided that the conditions for emergency measures still apply, see Article 11(5).

\section{Consultation of stakeholders}

When the Commission on request prepares fisheries measures in a Natura 2000 sites, it must consult Advisory Councils of the region according to Article 18(2), see Article 11(2) and Article 44(3).

The Common Fisheries policy should be guided by appropriate involvement of stakeholders, in particular of Advisory Councils, at all levels from conception to implementation of the measures; see Article 3(f) of the Basic Regulation.

\section{Scientific advice}

When the Commission prepares conservation measures the Commission consults relevant scientific bodies. Conservation measures must take into account available scientific, technical and economic advice. This may include reports drawn up by the Scientific, Technical and Economic Committee for Fisheries (STECF) and other advisory bodies, advice received from Advisory Councils and request by Member States in accordance with Article 18 (regionalisation); see Article 6(2).

The Scientific, Technical and Economic Committee for Fisheries (STECF) was set up by the Commission Decision of 19 November 1993 (93/619/EC). ${ }^{87}$ It can be consulted on matters related to the conservation and management of marine biological resources, to ensure the required assistance of highly qualified scientific personnel, particularly in the application of biological, economic, environmental, social and technical disciplines.

\section{Shared fish stocks}

If fishery measures in a Natura 2000 apply to a specific fish stock which is shared with countries outside the EU and if these stocks are managed by multilateral fisheries organisations or under bilateral and multilateral agreements, the EU must try to agree with the relevant partners on the

${ }^{87}$ http://eur-lex.europa.eu/LexUriServ/LexUriServ.do?uri=0J:L:1993:297:0025:0026:EN:PDF 
necessary measures. In this respect the measures should achieve the objectives of the CFP (environmentally sustainable in the long-term and are managed in a way that is consistent with the objectives of achieving economic, social and employment benefits, and of contributing to the availability of food supplies), see Article 18(4).

\section{Notification to the Parliament and to the Council}

The Commission's adoption of a delegated act is based on the request from Member States in the sea region and on scientific information.

Before the Commission adopts such acts, it is assisted by national experts (expert group). It is of particular importance that the Commission carries out appropriate consultations during its preparatory work for the adoption of delegated acts, including at expert level, see Consideration (67) of the Basic Regulation.

The Commission thus consults national experts at the Committee for Fisheries and Aquaculture meetings where such consultations will be on the agenda. All EU Member States are represented on the Committee.

As soon as the Commission adopts a delegated act, it must notify both the European Parliament and the Council, see Article 46(4). A delegated act adopted by the Commission enters into force within two months of the Commission's notification only if no objection has been expressed by the European Parliament and the Council, and the Parliament and the Council have both informed the Commission that they will not object, see Article 46(5). The two months will be extended by two months at the initiative of the European Parliament or of the Council. This delegation of power to the Commission to adopt conservation measures accompanying certain environmental obligations by Member States is taken according to Article 290 of the Treaty.

The power to adopt such fisheries conservation measures by means of delegated acts is conferred for a period of five years from 29 December 2013; see Article 46(2). This delegated power will be automatically extended for a new period, provided that the European Parliament or the Council do not oppose the extension, see Article 46(2). The European Parliament or the Council can by means of a decision revoke a specified delegation of power to the Commission at any time; see Article 46(3). Such a decision will not affect the validity of any delegated acts already in force; see Article 46(3). 


\section{Implementation of measures}

The Commission must facilitate cooperation between the Member State concerned and other Member States which have a direct management interest in the fishery concerned in the process of implementation and enforcement of the measures concerned see Article 11(6) of the Basic Regulation. 
Ved Stranden 18

DK-1061 Copenhagen K

www.norden.org

\section{Decision-making management procedures}

This study report analyses the strengths and weaknesses of the procedures which are followed when designating marine Natura 2000 sites and when deciding what fisheries management measures are to be applied.

The report identifies weaknesses in the current system and proposes to replace the existing procedures with a single-stringed system structuring the national and international processes in a single regional integrated environmental-fisheries process. This process should include extensive stakeholder involvement.

TemaNord 2014:532

ISBN978-92-893-2780-0

ISBN 978-92-893-2781-7 (EPUB)

ISSN 0908-6692

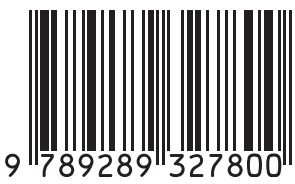

